\title{
An Exercise in Defining Democracy and its Implications for Russia, 2000-2008
}

\author{
by \\ Joanna K. Olender, B. Soc. Sci. \\ A thesis submitted to the Faculty of Graduate \\ Studies and Research in partial fulfillment of \\ the requirements for the degree of
}

Master of Arts

Institute of European, Russian, and Eurasian Studies

\section{Carleton University \\ Ottawa, ON}

January 2010

(C) 2010, Joanna K. Olender 


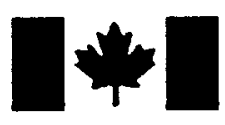

Library and Archives

Canada

Published Heritage

Branch

395 Wellington Street

Ottawa ON K1A ON4

Canada
Bibliotheque et

Archives Canada

Direction du

Patrimoine de l'édition

395, rue Wellington

Ottawa ON K1A ON4

Canada
Your file Votre référence

ISBN: 978-0-494-64439-3

Our file Notre référence

ISBN: 978-0-494-64439-3
NOTICE:

The author has granted a nonexclusive license allowing Library and Archives Canada to reproduce, publish, archive, preserve, conserve, communicate to the public by telecommunication or on the Internet, loan, distribute and sell theses worldwide, for commercial or noncommercial purposes, in microform, paper, electronic and/or any other formats.

The author retains copyright ownership and moral rights in this thesis. Neither the thesis nor substantial extracts from it may be printed or otherwise reproduced without the author's permission.
AVIS:

L'auteur a accordé une licence non exclusive permettant à la Bibliothèque et Archives Canada de reproduire, publier, archiver, sauvegarder, conserver, transmettre au public par télécommunication ou par l'Internet, prêter, distribuer et vendre des thèses partout dans le monde, à des fins commerciales ou autres, sur support microforme, papier, électronique et/ou autres formats.

L'auteur conserve la propriété du droit d'auteur et des droits moraux qui protège cette thèse. $\mathrm{Ni}$ la thèse ni des extraits substantiels de celle-ci ne doivent être imprimés ou autrement reproduits sans son autorisation.
In compliance with the Canadian Privacy Act some supporting forms may have been removed from this thesis.

While these forms may be included in the document page count, their removal does not represent any loss of content from the thesis.
Conformément à la loi canadienne sur la protection de la vie privée, quelques formulaires secondaires ont été enlevés de cette thèse.

Bien que ces formulaires aient inclus dans la pagination, il n'y aura aucun contenu manquant.

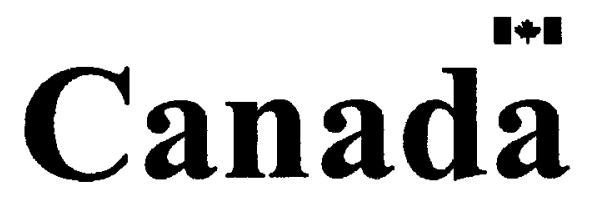




\begin{abstract}
This thesis explores whether democracy can be defined in a way that maintains its meaningfulness as a political science concept, while separating democracy from a de facto liberal democratic understanding. By examining major works of democratic theory, both classical and modern, I determine three key elements of democracy-popular control over the government, political equality, and freedom. I apply this conception of democracy to the case of Russia under the presidency of Vladimir Putin (2000 to 2008) to determine if, during this period, Russia could be considered democratic. An examination of public opinion polls and the results of national elections reveal that although Russia under Putin had a number of democratic elements, it cannot be considered a democratic state because of electoral fraud and the incumbents' use of administrative resources.
\end{abstract}




\section{Acknowledgements}

I would like to thank my supervisor, Dr. Joan DeBardeleben, and my second reader, Dr. Marc Hanvelt, for all their suggestions, help, and encouragement throughout the process of writing this thesis. I would also like to extend thanks to the Department of European, Russian, and Eurasian Studies (EURUS) at Carleton University and, in particular, Ginette Lafleur for all her assistance.

This project received a great boost from the Social Sciences and Humanities Research Council (SSHRC), to whom I am incredibly grateful for the financial support.

I also wish to thank Gleb Pistruga for all his support and help, particularly in assisting me with Russian language sources. I am very lucky to have such great encouragement from my friends and family, particularly my sister Jenna, who gave me excellent thesis writing advice and help with citations. 


\section{Table of Contents}

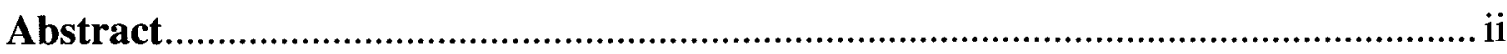

Acknowledgements ..................................................................................................iii

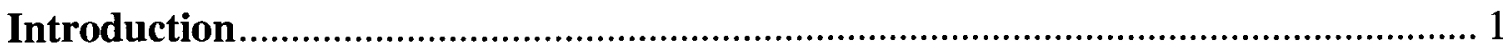

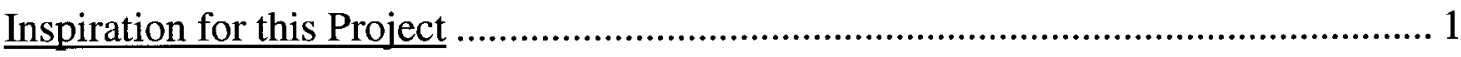

Preliminary Discussion of Democracy in Russia.............................................................. 3

Research Project.

Chapter 1: Contrasting Views on Russia's Democratic Transition .......................... 16

Perceptions of Vladimir Putin's Russia .......................................................................... 19

What emerges?

Chapter 2: An Overview of Democratic Theory ………………………………....... 46

The Essence of Democracy.................................................................................................. 46

The Development of Democracy .................................................................................... 53

Chapter 3: Liberal Democracy and an Alternative Definition................................. 71

Liberal Democracy............................................................................................................ 71

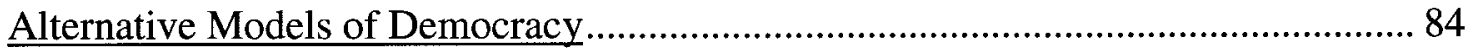

Chapter 4: Examining the Putin Years................................................................ 96

Russian Political Culture................................................................................................ 99

Public Opinion in Russia ........................................................................................... 103

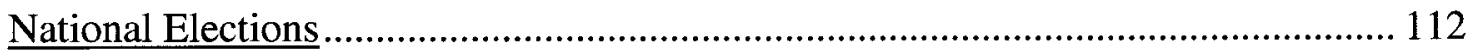

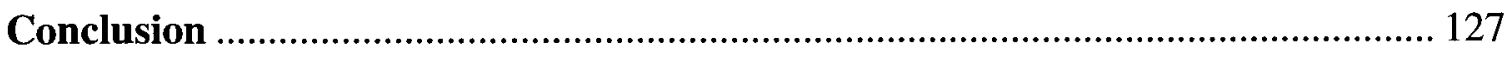

Freedom in Russia............................................................................................... 128

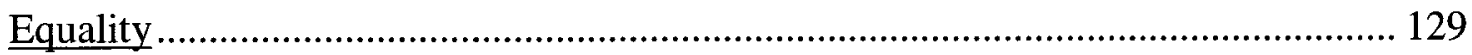

Popular Control of the Government........................................................................... 130

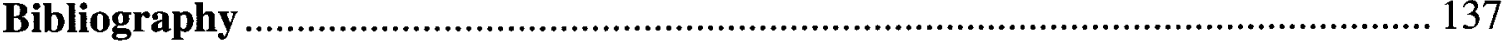




\section{Introduction}

$\underline{\text { Inspiration for this Project }}$

Before launching into a proper discussion of democracy in Russia, it is worthwhile to explain the thought process that inspired this thesis, as it may help the reader to understand the basic argument. The topic of this thesis is rather controversial, since I hypothesize that between 2000 and 2008, during the time that Vladimir Putin was president, Russia was democratic, or at least, had a number of democratic elements. This supposition challenges what many, if not most, western observers of Russia, both scholarly and journalistic, believe. The most popular stance on Russian democracy points to clampdowns on the media, extensive government control over society, and the repression of civil and political rights, as signs that there is no democracy in Russia or that the democracy that began to take shape in the 1990s under President Boris Yeltsin has been done away with. For example, Alfred B. Evans writes that a "consensus concerning the general character of Putin's administration has formed," and that "the real question is no longer whether Putin wants to decrease the degree of pluralism in the Russian polity, or whether he can successfully manipulate political forces to make that possible, since the answers to both these questions are obviously affirmative...."1

Yet, in Russia, there has been little opposition to Putin. He won majorities in both of the presidential elections in which he competed and public opinion polls throughout his time as head of state revealed a high level of support for him. Granted, the reader sceptical of my argument may be thinking, "Well, of course he did not face a great deal of opposition. People do not want to be thrown in prison for speaking out against him! It

\footnotetext{
${ }^{1}$ Alfred B. Evans, Jr., "Vladimir Putin's Design for Civil Society," in Russian Civil Society: A Critical Assessment, ed. Alfred B. Evans, Jr., Laura A. Henry, and Lisa McIntosh Sundstrom (Armonk, NY: M.E. Sharpe Inc., 2006), 148.
} 
is the lack of individual civil and political rights of citizens in Russia that dissuade them from criticizing the government; something, I may add, that is an essential part of democracy." However, this line of argument is unconvincing, since there is no reason for a majority of ordinary Russians to lie about their true feelings to researchers.

Firstly, Russia is not the Soviet Union and therefore has broken with a number of the traditions of the Russian Soviet Federative Socialist Republic, including the policy of punishing minor instances of civil disagreement with the government. ${ }^{2}$ Thus, there is no longer the same degree of pressure on Russian citizens to comply with the government's line, since the previously imminent threat of punishment for dissension has diminished greatly. ${ }^{3}$ Although anecdotal and lacking scientific rigour, during the four months of 2007 that I spent in St. Petersburg, Russia, I spoke to a number of people who told me that they supported Putin and several who said they did not. The fact that Russians would be willing to share their opinions about the president with a foreign student interested in studying Russian politics led me to believe that they would not have had qualms telling such things to any other researcher. There are other possible reasons to conceal true feelings, including, for example, a fear of seeming unpatriotic. Even still, it seems unlikely that this would cause a majority of respondents to fabricate their answers and votes, since the processes are anonymous and the respondents would not face the threat of punishment. It is possible that some respondents indicated support for Putin when they did not actually feel this way, to make them feel that they are on the "winning"

\footnotetext{
${ }^{2}$ There have been cases where oligarchs or other prominent figures in society have been accused of or punished for crimes such as tax evasion after expressing dissent with the government or their own political ambitions, such as in the cases of Mikhail Khodorkovsky, Boris Berezovsky, and Vladimir Gusinsky. It is, however, highly unlikely that the average Russian citizen, upon complaining of a policy or the country's leadership, would face punishment.

${ }^{3}$ See the discussion on the expression of opinions in chapter four.
} 
side of politics or to gain a sense of belonging within the majority. Surely, such a lack of self-esteem would not be widespread enough to change drastically the general outcomes of surveys and elections. Thus, I assume that a majority of those who say they supported Putin actually do. What does this mean, then, for democracy?

In the literal sense, the word democracy comes from the Greek word demokratia, which is of the root words "demos" meaning people and "kratos" or rule and thus, the term democracy implies some type of popular rule or, to use the oft-quoted phrase, 'rule by the people.' For people, such rule becomes connected to the idea of majority rule; that is, that a majority of citizens must support a particular proposition including the choice of a leader for it to become law. If this is the basis of democracy, then it can be assumed that when the wishes of a majority of the people who constitute a particular political unit are realized, it is then a democratic situation. In applying this reasoning to Russia, I purport that because a majority of citizens support Putin and presumably his policies, their democratic wish is that he would be the president and thus, even if some of the elements that constitute liberal democracy are not present, democracy was in practice. It is this idea - that democracy relies more on the wishes of citizens than on particular institutions-that inspired my research.

\section{Preliminary Discussion of Democracy in Russia}

In order to limit the scope of this undertaking and determine a precise research question, a useful starting point was to look at the reasons why most western scholars suggest that Russia is not democratic. In this body of literature, there are two major streams: the creation of subcategories within democracy in order to better describe Russia's circumstances, and studies that begin on the assumption that there is a spectrum 
between authoritarianism and democracy on which Russia has slid back toward authoritarianism, reversing its progress toward a democratic government. The first grouping of studies is based on the idea that Russia does have elements of democracy, but that this form of democracy is hollow or very limited. Essentially, these studies suggest that Russia is not democratic because, when compared to the countries that are part of the democratic core (Western Europe, the United States, Canada, and other countries that were once part of the British Empire), it is evident that Russia's version of democracy falls short.

An example of this type of study is "Managed Pluralism: Vladimir Putin's Emerging Regime," by Harley Balzer. The author analyses several of the 'adjectival forms' of democracy that have been used to characterize Putin's regime, such as 'illiberal democracy' and 'virtual democracy,' which all, at their heart, are used to convey the idea that although Russia has an outward appearance of democracy, there is something or perhaps many things missing from this system so that it cannot be equated with democracy as understood and practiced in the West. ${ }^{4}$ He suggests that 'managed pluralism' is a more appropriate term to describe Putin's style of rule, since Putin controlled the overall direction of many political aspects in Russia, but allowed a few "safe" options from which citizens can choose. ${ }^{5}$ However, this term suffers from the same major flaw as that of the adjectival qualifiers of democracy because in order to accurately define a particular regime type, a new term is added to the parlance, which has the result of either breaking the term democracy down into a multitude of subcategories,

\footnotetext{
${ }^{4}$ Harley Balzer, "Managed Pluralism: Vladimir Putin's Emerging Regime," Post-Soviet Affairs 19, no. 3 (2003): 193.

${ }^{5}$ Ibid., 191.
} 
so much so that the large category of 'democracy' becomes meaningless when comparing governments, or that democracy is completely removed from the analysis.

The second stream of studies on Russian democracy (or lack thereof) disregards labelling the political system and instead focuses on the degree of democracy present in Russia and the causes of this. For example, M. Steven Fish (2005) suggests that democracy in Russia has been "derailed" for reasons such as a concentration of power in the presidency, a lack of economic liberalization, and too great a reliance on oil revenue. Timothy J. Colton and Cindy Skach (2005) suggest that Russia is in a state of "democratic backsliding," due to problems inherent in its dual-executive system of government, which prompt the president to control the political process in order to overcome institutional disagreements. These studies tend to assume that there is a particular path to democracy with a clear endpoint and look for the roadblocks that prevent or force Russia to retreat from a democratic ends.

Overall, it seems that both streams of western literature on Russia's government are unsatisfactory, since they both compare Russia to the democratic standard of the West. The first stream evaluates Russia in terms of what its form of democracy lacks and then creates a new term to classify such a regime, adding another term to political discourse, which leads to a diluted discussion of regime types, where each regime has its own classification. The second grouping of studies embodies a slightly more useful approach to looking at Russia because it looks for specific factors that may prevent a democratic end. However, both groups suffer from the same flaws in thinking about democracy, as they equate democracy with the liberal democratic systems present in the 
'democratic core' and believe that such arrangements are the only workable forms of democracy.

My major disagreements with the presumed supremacy and universal applicability of liberal democracy are the false assumption that this political arrangement is the most legitimate form of rule and the implicit prescription that democratizing countries must follow the western model in order to become democratic. The western course of development may not be tenable for all countries, as democracy developed in the West under specific conditions. According to Barrington Moore's archetypal model, only through the historical steps of the weakening of the monarchy, the development of commercial agriculture, the weakening of the aristocracy, the prevention of a uppercommercial class alliance against peasants and workers, and a bourgeois revolution will a mix of capitalism and parliamentary democracy emerge. ${ }^{6}$ This mix developed into what is know as liberal democracy — a system of governance based on competitive party politics that places prime importance on individual liberties and the limitation of power. C. B. Macpherson also explicitly links a path-dependent historical process to liberal democracy. He explains that the liberal state developed out of capitalism, as "the government was put in a sort of market situation [where it] was treated as the supplier of certain political goods" and in order to sustain such a situation, individual liberties were guaranteed to the electorate and a system of party competition developed. ${ }^{7}$ Democracy was added only when the disenfranchised recognized that their political interests were not represented and thus demanded to be included in the political process. ${ }^{8}$

\footnotetext{
${ }^{6}$ Barrington Moore, Social Origins of Dictatorship and Democracy: Lord and Peasant in the Making of the Modern World (Boston: Beacon Press, 1966), 430-431.

${ }^{7}$ C.B. Macpherson, The Real World of Democracy (Oxford: Oxford University Press, 1966), 8-9.

${ }^{8}$ Ibid., 9.
} 
Based on an understanding of the development of democracy as a historical process, it would seem unlikely that a western-style democracy would flourish in countries like Russia, since it lacks the historical traditions identified by Moore and Macpherson. Many studies of the state of democracy under Putin confirm this supposition, as they conclude that the Russian democratic experiment is failing due chiefly to the fact that the presidential post has accumulated too much power. If transplanting liberal democracy is not successful in all cases, then something is wrong, either with the country trying to democratize, with the process of democratization, or with the concept of democracy itself.

In the first instance, where the problem is with the country itself, the core assumption is that democracy cannot function universally, unless countries adopt the political culture of the West. This conjecture is problematic for a couple of reasons. Firstly, blaming the circumstances of a country, its culture, history, or institutions for an unsuccessful attempt at democratizing is elitist and potentially Eurocentric since it implies that certain cultures—the ones that can democratize or have democratized—are superior to others. Secondly, as David Beetham argues, the basic principles of democracy, which he believes are political equality and popular control, are universal; that is, they are inherently good for all people and not culturally exclusive or incompatible with any culture. ${ }^{9}$ Amartya Sen agrees that democracy is universal, arguing that its importance to humanity has three aspects: intrinsic importance, since it adds value to human life; instrumental significance, in that democracy provides political incentives to keep governments responsible and accountable; a constructive role, by

\footnotetext{
${ }^{9}$ David Beetham, Democracy and Human Rights (Cambridge: Polity Press, 1999), 16.
} 
helping individuals to form values and to understand the needs, rights, and duties that citizenship entails. $^{10}$

Blaming a failed democracy on a poor or incomplete process of democratization is essentially blaming democracy itself, as the process of democratization is closely connected to the definition of democracy being promoted. For example, in the case of Russia, western experts promoted liberal democracy by encouraging the development of a capitalist economy through the introduction of "shock therapy," advising Russia to have elections and a representative legislature, and supporting the building of institutions to protect private property and individual rights. In actuality, the definition of democracy in the West (generally understood to be liberal democracy) means that western nations are not promoting democracy per se, but rather encouraging a particular set of institutions that constitute a particular manifestation of democracy. It is this manifestation of democracy and its associated political culture that failed to take root, but it is not necessarily a failure democracy itself. To understand democracy only as liberal democracy is to limit the possibility of successfully exporting democracy, since liberal democracy requires a particular political culture, based on historical and philosophical developments in the West. Indeed, in The Real World of Democracy, Macpherson emphasizes that liberal democracy is only one of the viable forms of democracy possible. It seems then that one of the major obstacles to the worldwide spread of democracy is the way in which the term is defined. If democracy were to be conceived of in a broader fashion than as de facto liberal democracy, then perhaps countries like Russia would be able to realize their own variants of true democracy, one more suitable to their unique histories and cultures.

${ }^{10}$ Amartya Sen, “Democracy as a Universal Value," Journal of Democracy 10, no. 3 (1999): 11. 


\section{$\underline{\text { Research Project }}$}

The previous discussion then leads to an interesting idea: whether democracy can be defined in such a way to make it less exclusionary, but still meaningful. This then prompts the research questions: What are the crucial elements of democracy and, by identifying these elements, do we then have a conception of democracy that is more culturally sensitive? These enquiries then lead to the question of whether Russia under Putin was democratic. I posit that a strong leader and democracy can coexist based on a more classical definition of democracy that focuses on the notion of "rule by the people" while still emphasising the importance of elections and other core elements of democracy. With this as a starting point, I hypothesize that if Russia's government has popular support, maintains the protection of minorities from the tyranny of the majority, and has regularly scheduled, fair, and competitive elections, then it should be considered democratic. A powerful executive branch and democracy are consistent when the president is working toward democratic ends and a majority of citizens support such ends as well as the policies to achieve them. In sum, the purpose of this thesis is to challenge the supremacy of liberal democracy as the only legitimate form of democratic governance, by determining if there is a different and defensible understanding of democracy and applying the criteria of this conception to the case of Russia.

Central to the conception of democracy used in this thesis project is a more classical understanding of the term, one that challenges the de facto connection between democracy and liberalism that seems so rampant in today's scholarship. Jean Grugel explains that this widespread association is a result of Cold War rhetoric aimed at discrediting the Soviet system, concluding, "In short, after 1945 democracy was 
successfully married to liberalism. Liberal democracy was no longer seen as one strand of democracy: it was presented as the only version there was." ${ }^{11}$ Contrary to the position of liberalism's primacy, I posit that the most important aspect of democracy is that a majority of citizens support those they have chosen to represent them and approve of their officials' policy decisions, even if these decisions seem to contradict liberal democratic notions. Conceptions of democracy that are distinct from liberalism and emphasize the role of collective agreement in democratic practices are not foreign to political theory. One of the most famous of these understandings is the idea of the "general will," first put forth by Jean Jacques Rousseau. This notion is discussed more fully in chapters two and three, so for the time being, it will only be briefly explained. Rousseau's solution for how to create a political authority that does not hamper human nature is to have, "the total alienation of each associate, and all his rights, to the whole community." 12 When individuals prioritize general interests over their personal interests, then their individual wills will be in common with those of others and thus, the general will has been identified. Although Rousseau's conception of the general will is distinct from majoritarianism, as he purports that everyone in society agrees with it, I use the general will in the sense of the majority's opinion.

The following hypothesis, which is tested in chapter four, links the concept of the general will to one of the main propositions of this research — that a variety of institutional arrangements of democracy, such as having a strong leader, are legitimate and possible. If the majority of Russia's citizens support Putin because they believe he will be the most beneficial ruler to Russia as a whole, then this is Russia's general will

\footnotetext{
${ }^{11}$ Jean Grugel, Democratization: A Critical Introduction (New York: Palgrave Macmillan, 2002), 17.

${ }^{12}$ Jean Jacques Rousseau, The Social Contract (New York: Hafner Publishing Co., 1947), 15.
} 
and therefore could be a basis for an alternative form of democracy to that of liberal democracy. However, this idea cannot be reasonably considered as a complete definition of democracy, since, by extension, it could include Nazi Germany as a democratic state, as Hitler came to power through a similar mechanism. Instead, the general will makes up only one part of the definition, which must include other aspects, namely the recognition of the main elements of democracy—popular control of the government, freedom, and equality, which are outlined in chapter two-and the protection of minorities. However, these notions are also part of a liberal understanding of democracy, which necessitates a more in depth look into liberalism in order to better understand the distinctions between democracy and liberal democracy.

Another, more modern, and non-liberal notion of democracy is what Macpherson terms the 'underdeveloped variant,' which is the form of democracy he believed to be present in post-colonial Africa and Asia at the time of writing. This type of democracy is characterized by a lack of liberal-individualist mentality, the importance of community over the individual, and a dominant single party that emerged during the struggle for independence, which had already proven its capacity to work in favour of the population and is thus supported by a majority of citizens (through, as Macpherson suggests, their general will) to undertake the construction of a new state. ${ }^{13}$ Although Russia is not a former colony, many of the conditions that Macpherson identifies as consistent with this type of democracy are applicable to the political culture of Russia, such as a communal tradition, a history without a dominant liberal strain, and the prominence of one political power, which is explored in greater depth in chapter four. Thus, there is a tradition in

\footnotetext{
${ }^{13}$ Macpherson, The Real World of Democracy, 24-26.
} 
political science to define democracy in different ways than just as liberal democracy and it is in this tradition that the basis for democracy presented in this paper will rest.

The scope of this project is Russia during the 'Putin years' (2000-2008), as this is the time period that many western observers have tagged, to use Graeme Gill's phrase, as Russia's "turn to authoritarianism". ${ }^{14}$ Although Putin maintains influence in Russia as Prime Minister, I have limited this study to the end of his second term as President because this allows me to more carefully consider a wide variety of resources than if I look into more recent events of which journalistic sources may only exist. Furthermore, limiting this study prevents current events from obscuring the major argument. An eightyear period is a rather large timeframe for examining such broad topics as democracy and democratization, which is why I had to limit the number of institutions examined in the case study.

In terms of methodology, this thesis project relies predominantly on research from written sources. Incorporated into the theoretical component will be reviews and discussions of literature on democracy to help ground and refine my own working definition of the term and to engage in debates about key aspects of democracy. As well as addressing some of the classics of political theory (Mill, Locke, Rousseau, etc.), I look to modern political theorists like C.B. MacPherson and Robert Dahl, who developed seminal theories of democracy. The case study section uses aggregated data from public opinion surveys, conducted by both western and Russian researchers. Throughout the thesis, where relevant, quotations from Russian politicians are included. Sources were located through keyword searches in the Ontario Scholars Portal database, through my own knowledge of the topics at hand, and by using the bibliographies of relevant books

${ }^{14}$ Graeme Gill, "A New Turn to Authoritarian Rule in Russia?" Democratization 13, no. 1 (2006): 58-77. 
and articles. In the case of Russian sources, once I identified an article of interest from a particular journal, I scanned the other issues of that journal to find additional articles. In general, I apply the Library of Congress' transliteration rules when using Russian words, unless an alternative spelling is more common than the Library of Congress spelling, such as is the case with several proper names used in this paper.

The general structure of this study consists of three major sections. The first will be a literature review of studies on democracy and democratization in Russia. In chapter one, I investigate a number of opinions on democracy under Putin, including those of Russian and western academics. This chapter addresses a gap I identified in existing western literature on Russian democratization, as these studies predominantly draw on only other western sources, thereby (and possibly inadvertently) dismissing the possibility of a different method of democratization and further perpetuating the current mode of thinking on Russia (i.e. that Putin and his administration are decidedly undemocratic or even anti-democratic). The contrasting of the reviews of Russian sources and western sources highlights the similarities and differences in how scholars from both academic communities view democracy and democratization in Russia. Furthermore, the use of Russian articles contributes to a better understanding of Russian political culture and presents explanations as to why Russia should follow a different course of democratization to that of the western model. As part of my exploration of Russian sources used in other chapters, I utilize speeches and articles by Putin and other politicians, as well as public opinion polls conducted by Russian agencies. I hope that by examining the Russian perspective on particular issues relevant to this thesis, I can present a balanced approach to the topic of democracy in Russia. 
The second section will address the larger theoretical discussion of democracy. The general will is a sound starting point for examining alternative configurations of democracy through the idea of mass support; however, before explaining this concept in greater detail, chapter two contains a broad overview of democracy. It explores the development of democracy in order to identify the core elements of this system. Chapter three includes a discussion of liberalism as well as of other models of democracy. An examination of liberalism and its importance to democracy is necessitated by arguments like that of Fareed Zakaria, who posits that a lack of liberalism makes democracy meaningless. ${ }^{15}$ It is in the conclusion to this chapter that I present the core essentials of a culturally sensitive model of democracy.

The third major section is a case study of public opinion and elections in Russia. The fourth chapter will use criteria for democracy developed in the first section along with available empirical evidence from public opinion polls and surveys to determine whether Russia under Putin could be considered democratic when using a culturally neutral definition of democracy. If the data are consistent with the definition of democracy, then it can be said that Russia was democratic under Putin, despite his tendency to centralize power. The case study will focus on three aspects of Russiapolitical culture, public opinion, and elections. These three areas are most relevant to the proposed study, as political culture helps to explain the necessity for a different 'type' of democracy (as opposed to the liberal democratic model), public opinion is the main variable around which my conception of democracy revolves, and elections are a cornerstone of the democratic process. Certainly, both elections and public support are legitimizing to any government, but, in order to assess whether they are democratic, it is

${ }^{15}$ Fareed Zakaria, "The Rise of Illiberal Democracy," Foreign Affairs 76, no. 6 (1997): 22-43. 
necessary to look at how opinions are formed and the role that the government plays in trying to control public opinion. The ultimate goal of the case study section is to examine whether a different conception of democracy (i.e. the result of the theory section) is being employed in Russia, and therefore, whether Russia could be considered democratic. The results of my analysis are presented in the concluding chapter. 


\section{Chapter 1: Contrasting Views on Russia's Democratic Transition}

The primary aim of this chapter is to provide two types of background information relevant to this study: a brief look at Russian history following the dissolution of the Soviet Union and a review of literature on democratization (or the lack thereof) in Russia during Putin's tenure as President of the Russian Federation. In the literature review, I seek to identify similarities and differences between the Russian and western literature in how Putin's presidency affected democracy or democratization in Russia. However, I begin by briefly focussing on retrospective appraisals of Russia's years under Yeltsin, as this can aid in understanding the conditions of the Russian system that Putin inherited when he took office. The policies and changes that occurred under Yeltsin had a significant impact on the mentality of both ordinary Russians and their political leaders. As such, it is useful for the reader to be aware of the effects that Russia's first foray into democracy had on society.

When considering this period of Russia's development, the common western view is that under the presidency of Boris Yeltsin, Russia began to democratize by holding competitive elections, implementing a multiparty system, and undertaking privatization policies. Furthermore, as Lilia Shevtsova notes, the West, pleased by Yeltsin's opposition to communism and friendly foreign policy, tended to believe that Russia was becoming more democratic, though the country lacked the developed institutions that would support democracy and capitalism, like a functional legal system, incorrupt financial institutions, and political pluralism. ${ }^{1}$ Although Yeltsin's rule had undemocratic elements, such as his tendency to increase the power of the president's office and the

\footnotetext{
${ }^{1}$ Lilia Shevtsova, Russia - Lost in Transition (Washington: Carnegie Endowment for International Peace, 2007), 22.
} 
oligarchs' control of the country's resources, the West was willing to overlook these 'glitches' in favour of ensuring that Russia stays on its democratic course, since the major political opposition at that time was the Communist Party. ${ }^{2}$

In addition, Yeltsin's government was willing to listen to and take advice from the West, including a package of economic reforms that included freeing prices, privatizing publically owned assets, liberalizing trade, and drastically reducing levels of state subsidization, collectively known as "shock therapy." While privatization allowed a few Russians to become extraordinarily wealthy and, as a consequence, politically powerful, for the majority of Russians, these policies resulted in a drastic decrease in living standards compared to what they once had under the Soviet system. In the words of Ellen Carnaghan, "Inflation soared, real incomes plummeted, and those in power seemed more interested in who would defeat whom than in solving the problems that ordinary people faced." ${ }^{\prime 3}$ As a result, democracy came to be perceived as something negative to many Russians, since it was used to describe a regime of crony capitalism, robber-baronism, chaos, lawlessness, corruption, and the decline of social protections. Although praising Yeltsin for his role in deconstructing the Soviet system, Michael McFaul and his colleagues observe that Russia's first president did not excel at building democracy. Rather, when Yeltsin passed the presidency to Vladimir Putin on New Year's Eve, 1999, he left Russia with a flawed democratic system: .... constitution that gave overweening power to the president; a fledgling party system; a weak and detached civil society; a media sector incapable of turning a profit,

\footnotetext{
${ }^{2}$ Shevtsova, Russia - Lost in Transition, 23.

${ }^{3}$ Ellen Carnaghan, Out of Order: Russian Political Values in an Imperfect World (University Park, Penn.: Pennsylvania State University Press, 2007), 9-10.
} 
and therefore dependent on owners with political motivations; and corrupt and ineffective legal institutions. ${ }^{4}$

Nevertheless, there was still an overwhelming impression in the West that this_-at least compared to the Soviet system-was the start of democratization in Russia.

However, from 2000-2008, during the time that Putin was president, many western observers claim that Russia "retreated" in its democratic progress, often blaming the policies of the new president. Frequently connected to the argument that Russia has reduced its degree of democracy are the implications that this is harmful to Russians or Russian society or that such actions make Russia's government less legitimate. Although this line of argument is most prevalent in western media, it is by no means the only position on Russia under Putin. A variety of opinions on this topic is explored in the following literature review. It should be noted, however, that I focus on only macro level examinations of democracy in Russia. This type of study tends to be less nuanced in its appraisal of Russia than studies which focus on particular aspects of a democratic system (i.e. studies specifically on the multiparty system, Russia's legal code, or electoral practices, etc.). However, adequately covering such a large body of literature and addressing varied opinions on each institution of democracy would have been difficult, which is why I only look at studies on the broader topic of democracy and democratization under Putin. Resulting from this approach is a more stark contrast in views than perhaps exists in reality, since the studies on particular aspects of democracy, which are largely empirical and consequently less biased, are excluded.

In order to discuss the differing opinions on Russian democracy, I divide the books and articles reviewed into two groups-western scholars and Russian scholars.

\footnotetext{
${ }^{4}$ Michael McFaul, Nikolai Petrov, and Andrei Ryabov, Between Dictatorship and Democracy: Russian Post-Communist Political Reform (Washington: Carnegie Endowment for International Peace, 2004), 292.
} 
This division is meant to reflect the viewpoint from which the authors would be writing, and is based not only on their ethnicity and place of residence, but also on the organizations for which they work. In cases where there is a Russian author collaborating with a western one, I classified these works as western, since they were published in English and aimed at a western audience. ${ }^{5}$ However, in a couple of cases, books or articles that were published in English but by Russian authors were classified as Russian works because of the authors' affiliations with Russian institutions. ${ }^{6}$ I chose to divide the literature in this way because it helps to highlight the contrast in viewpoints on democratization in Russia, particularly since the Russian perspectives are rarely acknowledged in the literature reviews of western books on democratization in Russia. Furthermore, rather than looking at western and Russian sources as separate groups, I proceed through the literature review by position towards the subject matter, looking at arguments presented by both western and Russian scholars. Although this approach may make it more difficult to follow in which set of literature each author belongs, it demonstrates more clearly the similarities and differences between the two sets of literature.

\section{Perceptions of Vladimir Putin's Russia}

In Between Dictatorship and Democracy, Michael McFaul, Nikolai Petrov, and Andrei Ryabov argue that Russia did adopt a "form of democracy" in the 1990s, but began to move in an "antidemocratic direction" under the leadership of Putin. ${ }^{7}$ This

\footnotetext{
${ }^{5}$ This includes the article by Kryshtanovskaya and White and the book by McFaul, Petrov, and Ryabov. Other works classified as western include those by Balzer, Carnaghan, Colton and Skach, Fish, Gill, and Shleifer.

${ }^{6}$ These include the articles by Migranyan, Pushkov, and Ryzhkov as well as the book by Shevtsova. The other Russian sources are by Khrustov, Morozov, Nalivkina, Naumov and Slonov, Petukhov, Shimov, and Vitushkin.

${ }^{7}$ McFaul, Petrov, and Ryabov, Between Dictatorship and Democracy, 2.
} 
assessment is based on evaluations of various features of the Russian system (including the electoral and party systems, the Constitution, relations between branches of government, civil society, mass media, federalism, and perceptions of democracy) against a model of liberal democracy, as defined by Larry Diamond. ${ }^{8}$ Interestingly, the authors defend their method of comparing Russia to a liberal democratic ideal and pointing out how the country falls short as not being 'ethnocentric or American-centric' because, “...the deployment of lesser criteria [is] analytically circumspect and politically selfdefeating for those in Russia and the West seriously committed to further democratization in Russia." However, this justification is inadequate since it does not explain why liberal democracy is the only acceptable form of democracy to use in evaluations. Furthermore, it does not acknowledge that comparing Russia to a liberal standard may be 'self-defeating' for political scientists interested in democracy, since Russia does not necessarily have a liberal tradition to support such institutions, though it may have legitimately democratic features.

In Democracy Derailed in Russia: The Failure of Open Politics, M. Steven Fish argues that the interplay between "too much oil, too little economic liberalization, and too weak a national legislature," have inhibited Russia's progress toward democracy. ${ }^{10}$ According to Fish, Russia's vast natural resources have negatively affected economic liberalization policies and have contributed to a high degree of corruption, which

\footnotetext{
${ }^{8}$ Diamond's criteria include control of the state by elected officials, including the subordination of the armed forces to civilian officials; limited executive power; elections between multiple contestants where the outcome is unknown beforehand; the protection of minority groups; a vibrant civil society; access to multiple and independent sources of information; the protection of individual freedoms; equality of citizens under the law; an independent and unbiased judiciary; and laws that protect citizens from undue harm (McFaul, Petrov, and Ryabov, Between Dictatorship and Democracy, 3-4).

${ }^{9} \mathrm{McFaul}$, Petrov, and Ryabov, Between Dictatorship and Democracy, 5.

${ }^{10}$ M. Steven Fish, Democracy Derailed in Russia: The Failure of Open Politics (Cambridge: Cambridge University Press, 2005), 27.
} 
undercuts both elite and mass support for democracy. Economic liberalization is vital for the creation of a more open political atmosphere because it creates a base for the growth of civil society and can reduce citizen dependence on the state by increasing and broadening the number of people in control of economic resources. It also could reduce corruption in society, as economic liberalization impedes the state's ability to use patronage as a means of political control. Fish argues that in Russia's case, economic reforms were instituted too gradually and in an incomplete fashion, thus sustaining economic statism and hindering the development of civil society and democracy. Furthermore, Fish posits that a strong national legislature is conducive to openness and democracy. Russia's constitution, however, is structured in such a way that it has emasculated the legislature in favour of "superpresidentialism," which delegates an inordinate amount of power to the president and thus does not encourage party development, undermines the proper functioning of government departments, and exacerbates corruption.

Fish's methodology is similar to that which was employed in Between Dictatorship and Democracy, since he compares Russia to democratic and nondemocratic countries with the use of Robert Dahl's criteria for "polyarchy" 11 and then uses these comparisons to identify in which areas Russia is failing to meet democratic standards and attempts to explain why this is so. Since Fish is also comparing Russia to a theoretical standard and identifying where the country falls short, his work is likewise vulnerable to the same criticism of ethnocentrism as McFaul and company, particularly since it is obvious that Fish assumes a western-style government of liberal economic policies with a powerful legislature is the only acceptable form for a democratic state.

\footnotetext{
${ }^{11}$ See chapter 2 for an explanation of polyarchy.
} 
Olga Kryshtanovskaya and Stephen White present a somewhat more restrained criticism of Russia's lack of democracy in "Putin's Militocracy," if only because they look at a sole factor-the bureaucracy. According to the authors, a militocracy is a government with a large number of employees from military or security backgrounds, especially (and in the particular case of Russia) in the President's inner circle, which includes the President himself, and the power ministries. The authors argue that Putin was selected for president because his background would make him predisposed to restore order in Russia after the excesses of the Yeltsin years. Putin then surrounded himself with people he trusted, who are mostly of the same employment background and thus, the militocracy was born. Due to their particular upbringing in the Red Army or KGB, this group of officials is well suited to following orders; however, they have not fully 'converted' to democratic values. Kryshtanovskaya and White suggest that "[the officials'] Marxism-Leninism gave way to a set of values that contained more elements of Slavophilism and patriotism, combined with an economic philosophy that accepted the necessity of private property and the market."12 This is problematic because a large proportion of high-ranking bureaucrats do not fully support democracy and thus, democratization will not be a priority. Furthermore, Kryshtanovskaya and White suggest that, "... a change in quantity must necessarily lead to a change in quality. In this respect the authoritarian methods that are inherent in military structures might be transferred to society as a whole." ${ }^{13}$ Kryshtanovskaya and White believe that the more Russia moves in the direction of militocracy, the more its political situation will mimic that of the Soviet Union; in other words, this conclusion could be interpreted to say that Putin has moved

\footnotetext{
${ }^{12}$ Olga Kryshtanovskaya and Stephen White, "Putin's Militocracy," Post-Soviet Affairs 19, no. 4 (2003): 303.

${ }^{13}$ Ibid., 303-304.
} 
Russia toward authoritarianism, although the authors suggest that it is highly unlikely that Putin and his cohorts would attempt to instate a fully authoritarian system. ${ }^{14}$

In “Managed Pluralism: Vladimir Putin's Emerging Regime," Harley Balzer attempts to find an appropriate label for Putin's government, since he believes that neither the language of democracy nor authoritarianism adequately captures how the government functions. Balzer selects 'managed pluralism' since it highlights Putin's desire for central control, while at the same time allowing for a few alternatives, albeit ones that are perceived to be less threatening and least different from the status quo. ${ }^{15}$ To demonstrate the appropriateness of this term, Balzer examines Putin's treatment of religion, political parties, mass media, labour unions, civil society, and Russia's regions, demonstrating how there is some pluralism within these spheres, but that Putin tries to orchestrate the overarching direction of each. Both the works by Balzer and Kryshtanovskaya and White also compare Russia to a western model, although these comparisons, rather than showing how Russia falls short, instead try to label Putin's 'unwestern' regime. In addition, both studies implicitly include a rating system of governments by suggesting that Russia is more autocratic than a state should be, and therefore the authors imply that the Russian government is not as respectable or legitimate as those that have a less powerful executive branch.

The position that the Putin administration has been detrimental to Russia's democratization is present not only in western scholarship, as Russian scholars also put forth this viewpoint (though, unlike in the western literature, it seems to be the minority position amongst Russian academics). It is pertinent to note that Russian critiques of

\footnotetext{
${ }^{14}$ Kryshtanovskaya and White, "Putin's Militocracy," 304.

${ }^{15}$ Harley Balzer, "Managed Pluralism: Vladimir Putin's Emerging Regime," Post-Soviet Affairs 19, no. 3 (2003): 191.
} 
Putin's government are often published in English, perhaps because they will then be accessible to a broader sympathetic audience. Although I did not conduct an exhaustive literature review and therefore cannot make any conclusive statements regarding all viewpoints expressed on the topic of the state of democracy under Putin, it is interesting that the reviewed article critical of Putin and written in Russian is from an online journal, whereas articles from Russian printed periodicals are generally supportive of the government. This suggests either that the position that Putin is in some way hurting Russian society by 'backtracking' on democratic gains is unpopular or even implausible or that the Russian scholars who would be critical of their government tend not to state such points for fear of marginalization in academia or other repercussions.

In Russia - Lost in Transition, Lilia Shevtsova presents an argument on Russian politics and Putin's government that reads more like an opinion piece in a newspaper than a scholarly book with extensive empirical evidence and citations. She argues that Putin only had three options for Russia's political trajectory from which to choose-liberal democracy, market-oriented authoritarianism, or bureaucratic capitalism-and that he chose the third option, using officialdom to recapture control of the state while still promoting the values of private property and the market. ${ }^{16}$ Interestingly, Shevtsova does not consider or perhaps even perceive that there could be a fourth option, non-liberal democracy. Furthermore, she argues that Putin orchestrated a regime of "imitation democracy,' whereby some ceremonial features of democracy are used to obscure 'authoritarian, oligarchic, or bureaucratic' trends. ${ }^{17}$ While Russia - Lost in Transition is a translation from Shevtsova's Russian original, it reads very much like a typical western

\footnotetext{
${ }^{16}$ Shevtsova, Russia - Lost in Transition, 69 and 46.

${ }^{17}$ Ibid., 49.
} 
book on Putin's Russia, whereby the author is critical of the government and assumes that liberal democracy is the only suitable political system for Russia. Although authors like Shevtsova, who claim the supremacy of liberal democracy, rarely expand upon why this is so, they assume any other system would be detrimental to citizens and therefore that the inherent desirability of liberal democracy is widely understood.

Vladimir Ryzhkov, a liberal politician, who was a member of the State Duma from 1993 to 2007, wrote an article highly critical of Putin for the Journal of Democracy, arguing that Putin's government relies on 'authoritarian modernization,' whereby the economic and social development of Russia is undertaken through an autocratic government that promotes an open market economy. ${ }^{18}$ He accuses Putin of fabricating his popularity, controlling the media, and eliminating the possible routes to oppose his power. ${ }^{19}$ Ryzhkov suggests that Putin selected an authoritarian modernization model of development in reaction to previous state models, rejecting communism through his market orientation and rejecting Yeltsin's style of rule through his reduction of the power and influence of the oligarchs. Ryzhkov contends it is this idea-the rejection of the past-that makes Putin seem so attractive to many Russians, as both the communists and liberals are associated with unpleasant times. ${ }^{20}$ Nevertheless, Ryzhkov believes that Russia would be better under the control of a liberal regime and ultimately, will reject Putin's model of modernization in favour of a revived liberal movement.

Like Shevtsova, Iaroslav Shimov, in "The Era of Vladimir Putin and the transformation of the Russian state," takes a critical stance toward Putin's 'authoritarian stabilization.' Shimov argues that Putin and his administration manipulated the

\footnotetext{
${ }^{18}$ Vladimir Ryzhkov, “The Liberal Debacle," Journal of Democracy 15, no. 3 (2004): 53.

${ }^{19}$ Ibid., 53.

${ }^{20}$ Ibid., 54 .
} 
population into supporting the centralization of power and restrictions on some liberties through the idea of "strengthening the state after a decade of collapse." 21 He believes that Russia is a faux-democracy; an authoritarian regime camouflaged in a democratic form. ${ }^{22}$ What distinguishes Shimov's opinions from those of his western contemporaries is his temperance in criticism. Whereas western commentators discuss the restriction of freedoms and civil liberties in broad terms, Shimov implies that such restrictions only applied in a limited number of cases. For example, Fish writes, "Control, manipulation, and repression are not limited to communicative interaction. Restrictions on associational freedoms also characterize official action and policy,"23 ${ }^{, 2}$ wereas Shimov explains that the restriction of civil liberties was "not too rigid" and only applied to "certain civil liberties" while there was a "partial dilution of others," which was supported, through passive indifference, by the majority of the Russian population. ${ }^{24}$ Furthermore, Shimov's writing also differs from the reviewed western sources in its rejection of a western model for Russia. Shimov believes that it is more productive to assess Russia based on its historical development, rather than through applying a universal template or comparing its progress to western nations. Although Shimov's article is more critical of the Putin regime than most other works by Russian scholars reviewed in this chapter, it shares with them in a common theme found only in the Russian literature-the idea that Russia should not be compared to the West.

${ }^{21}$ Author's translation of “...укрепления государственности после десятилетия развала.” (Iaroslav Shimov, "Epokha Vladimira Putina i transformatsiia rossiiskoi gosudarstvennosti," Neprikosnovennyi zapas 57 , no. 1 (2008).)

22 Shimov, "Epokha Vladimira Putina."

${ }^{23}$ Fish, Democracy Derailed in Russia, 75.

24 Taken from the following quote: "Это сопровождалось определенным, хоть и не слишком жестким ограничением одних гражданских свобод (например, свободы слова) и частичным выхолащиванием других (например, свободы политического выбора). Такая политика проводилась при поддержке скорее пассивно-равнодушной, чем активной, - явного большинства населения." (Shimov, "Epokha Vladimira Putina.") 
The second common position found in both sets of literature is that Putin is continuing with what came before him, rather than changing Russia's political trajectory or reversing democratic gains. Shevtsova posits this, writing that: ...the crucial factor that explains how Putin's rule developed is the logic of the system he inherited from Yeltsin. It was under the first president of Russia that a constitution was adopted that placed the leader above society and created the framework for further development. It was under Yeltsin that a privatization took place that bound the regime and business to each other. It was under Yeltsin that the mass disenchantment with liberal democracy began, as it came to be associated in the popular mind with corruption and the exercise of power by shadowy factions. It was under Yeltsin that society started to look for a strong leader who would restore order. Even if, against all the odds, a true democrat had come to power in 2000 , he would have been hard pressed to steer the country in a different direction. There was no popular force in Russian society capable of implementing a democratic agenda, and besides, people were tired and had no wish to endure another bout of painful reforms. ${ }^{25}$

Although Shevtsova believes that Putin was building on what came before him, she also believes that he worsened the situation by not rectifying any of the problems from Yeltsin's time in power and exacerbating some by decreasing freedoms and further increasing the power of the presidency.

Graeme Gill presents a similar sort of argument in "A New Turn to Authoritarian Rule in Russia?". He posits that under both Mikhail Gorbachev and, in particular, Yeltsin, political elites were able to act independently of the general population and budding civil society groups, which constructed a system where the public had little involvement in civic life and that Putin inherited and sustained this state of affairs. Gill highlights five key elements from Yeltsin's rule that privileged an elite group and stunted

${ }^{25}$ Shevtsova, Russia - Lost in Transition, 42. 
the democratic development of institutions: Yeltsin's decision to remain above party politics by not associating himself with a political party hindered party growth and development in the formative years of democratic development; the institutions that could hold elites accountable_elections and the legislature-were weakly developed, which reduced the avenues through which citizens could participate in the popular control of their government; the position of president became based around charisma and Yeltsin's "ties to the people," which bypassed using institutions to moderate contact between the population and their leader; and the president created a bureaucracy that was specifically loyal to him, rather than the Russian state, thus making personal relationships and ties to people in power crucial to a governmental career. ${ }^{26}$ Gill concludes that even if “...Putin has clearly strengthened the position of the presidency compared with what it was under Yeltsin,... he has done so principally by using the same basic strategy as his predecessor, the closing-off of independent channels of participation in the polity." 27 In this sense, Putin did not break from or reverse democratic trends; he simply extended the path that was already there.

Although Genrikh Khrustov primarily examines why democracy lost popularity in Russia, his article also suggests that Putin's style of governance had its genesis in the Yeltsin years. The crux of his argument revolves around the failures of the democrats in the 1990s. Khrustov suggests that at the time of the formation of the Russian Federation, the democrats understood liberty as freedom from a dictatorial government, rather than as an order for society and as such, they focussed on ensuring the freedoms of movement and expression and freedom from tyranny, rather than on institutionalizing democratic

\footnotetext{
${ }^{26}$ Graeme Gill, “A New Turn to Authoritarian Rule in Russia?” Democratization 13, no. 1 (2006): 66-67.

${ }^{27}$ Ibid., 73.
} 
practices and law and order. ${ }^{28}$ Furthermore, according to Khrustov, the democrats, who lacked a proper understanding of how democracies function, believed that the population would continue to support their reforms regardless of any subsequent hardships. Because of this incorrect assumption, the democrats did not understand that they would need to change their policies according to the views of the electorate in order to keep the popular support. The resulting disillusionment of the politicians with democracy gave rise to the popularity of an authoritarian model of development amongst the "democrats" of Russia. $^{29}$ If we accept Khrustov's argument, then Putin's policies can be seen as a continuation of those of the Yeltsin era democrats, rather than a break with a more democratic past, as Putin simply maintained the final policy direction of Yeltsin's administration. Furthermore, some of Putin's policies that are suggested to be contradictory to democracy, such as arresting some of Russia's oligarchs and diminishing regional power centres by replacing the election of regional governors with presidential appointments, can be viewed as steps to create the 'institutionalized freedom' and order that was lacking in the 1990s.

Timothy Colton and Cindy Skach also suggest that Putin's system is a continuation of Yeltsin's and in doing so, take a closer look at one of the causes of the decline in democracy identified by Fish-superpresidentialism. In "The Russian Predicament," they argue that Russia's constitutional framework promoted 'democratic backsliding' instead of 'democratic consolidation. ${ }^{30}$ According to the authors, problems inherent in Russia's dual-executive system of government-a system in which the head

\footnotetext{
${ }^{28}$ Genrikh Khrustov, "Sud'by demokratii v Rossii," Polis politicheskie issledovaniia 1, no. 103 (2008): 185.

${ }^{29}$ Ibid., 186.

${ }^{30}$ Timothy Colton and Cindy Skach, "The Russian Predicament," Journal of Democracy 16, no. 3 (2005): 113.
} 
of state shares executive power with the head of the legislature-prompted the president to control the political process in order to overcome institutional disagreements. They argue that the Russian version of a semipresidential system, a divided minority government, inhibits democracy by weakening the legislature since the president assumes additional powers in order to pass laws instead of leaving the task of legislating to the Duma. $^{31}$ This state of affairs came about under Yeltsin, when he needed to overcome legislative immobilism in 1993; however, Putin has not attempted to rectify this situation through reducing the scope of power granted to the post of president. The authors suggest that, in effect, the State Duma has become a body to 'rubber stamp' presidential policies. Like most of the other authors who subscribe to the belief that Putin did not change Russia's political trajectory, Colton and Skach criticise Putin for perpetuating and not reversing authoritarian trends that developed under Yeltsin.

The two most common views presented in the reviewed Russian literature are that Russia has its own path to democracy, which the country is following, and, as previously mentioned, that a western model of democratization and democracy are unsuited to Russia. Basing his work on public opinion surveys conducted by VTsIOM in 2005 , Vladimir Petukhov presents data that show the Russian population's rejection of liberal democracy and a prevailing level of support for some features of the Russian system that are often criticized by the West. For example, the respondents rejected the concept of liberalism, but reacted favourably towards the notions of order and justice. ${ }^{32}$

\footnotetext{
${ }^{31}$ Colton and Skach put forth three variations of semipresidentialism: a consolidated majority government, in which both the president and prime minister are supported by the same party that holds a majority in the legislature; a divided majority government, in which the prime minister, but not the president, has a legislative majority; and a divided minority government, in which neither the president nor the prime minister have legislative majorities. ("The Russian Predicament," 116.)

${ }^{32}$ Vladimir Petukhov, "Perspektivy transformatsii: Dinamika ideino-politicheskikh predpochtenii rossiian," Svobodnaia mysl' 1556, no. 6 (2005): 62.
} 
Furthermore, the majority of respondents linked the notion of social justice with the ideas of a strong state, social order, and national interest, while only a minority connected justice to the development of democracy or to freedom. ${ }^{33}$ Putukhov notes, however, that the population's desire for order does not translate into a desire for a return to an authoritarian state, as democracy is viewed as a means to provide decent living standards. ${ }^{34}$ Although Petukhov does not use the VTsIOM findings to state definitively that Russia should not base its political or social development on a western model, the statistics included in his article all seem to point toward this point, implying that a Russian form of democracy is supported by a majority of Russians.

In "Perspectives of a right-conservative ideology in modern Russia," Dmitrii Vitushkin argues this point more categorically. He writes that the liberal reforms of the 1990s proved that changes that do not take into account the historical specificity of Russia's development will not take root and flourish. ${ }^{35}$ Instead, Vitushkin puts forth a "right-conservative" model for Russia to follow, which he believes is more suitable to Russia's moderate market economy and national character, since it stresses values such as patriotism, a strong state, community, order, stability, adherence to customs and traditions, morality, gradual economic and social development, and respect for private property. ${ }^{36}$ Although noting that Putin does not explicitly subscribe to this ideology, Vitushkin suggests that Putin's policies do fit the model of right-conservatism, which coincides with a rise in Russians who support such values and consider themselves

\footnotetext{
${ }^{33}$ Petukhov, "Perspektivy transformatsii," 64.

${ }^{34}$ Ibid., 63.

${ }^{35}$ D. A. Vitushkin, "Perspektivy pravokonservativnoi ideologii v sovremennoi rossii," Politanaliz, http://politanaliz.land.ru/right-conservatism1.htm, 2006, 1.

${ }^{36}$ Ibid., 2.
} 
conservatives. ${ }^{37}$ Despite the fact that this article does not specifically address

democratization in Russia, it does support the notion that Russia has its own course of development that does not match that of the West. It is also worth noting that this article does not suggest hostility toward democracy, but only that the form that is practiced in the West-liberal democracy_is not suitable to Russian culture, whereas Putin's style of rule is appropriate.

Vitushkin's notion of a right-conservative movement complements the idea of Russia as its own civilization - a place distinct, but equal to Europe, with its own culture and governing model. This idea has existed in Russian literature and philosophy for a few hundred years, first as part of the Slavophile ideology, which then was adopted into the Eurasianist movement in Russian political thought. Many Eurasianists believe that Russia is a civilization that, in a Huntington-esque fashion, will clash with the West and the Islamic world. ${ }^{38}$ For example, Aleksandr Prokhanov, the editor of the newspaper Den', argues for a return to an imperial state that would conduct a civilizational struggle against the West, since he believes that the West has promoted Islamic fundamentalism in Central Asia to undermine first the USSR and then Russia. Aleksandr Dugin builds upon this argument by tracing the civilizational conflict to pre-Soviet times, suggesting an "age-old" struggle between Eurasia and the oceanic powers of Britain and North America. ${ }^{39}$ However, Eurasianists are not against democracy, just the version that exists in the West. For example, Dugin supports the idea of democracy in Russia, but of an

\footnotetext{
${ }^{37}$ Vitushkin, "Perspektivy pravokonservativnoi ideologii," 7.

${ }^{38}$ Samuel Huntington, who believes that there is a distinct Slavic-Orthodox civilization, notes the rise in Eurasianism and warns that if Russians reject Western values and "begin behaving like Russians" then there could be a fault line between Russia and Western Europe. He also points out a potential (and, in light of recent geopolitical events, highly plausible) conflict between Russia and the Islamic states to its southern border. ("The Clash of Civilizations?" Foreign Affairs 72, no. 3 (1993): 45, 33.)

${ }^{39}$ Peter J.S. Duncan, "Contemporary Russian Identity Between East and West," The Historical Journal 48, no. 1 (2005): 288.
} 
"organic" (organicheskoi) variety, which is not based on the freedom of individuals (as is the liberal variant of democracy), but rather which sees the population as a living and indivisible organism, or alternatively, in a collective sense. ${ }^{40}$

Influences of Eurasianist thinking can be seen in the attitudes of Russian scholars towards democracy and democratization in Russia. In "Sovereign Democracy: Again to the question of terminology," Sergei Naumov and Nikolai Slonov look at a term for Russia's form of democracy that gained popularity during Putin's second termsovereign democracy. This term was coined by United Russia's Vladislav Surkov in $2006,{ }^{41}$ who explains that in addition to taking into consideration national and cultural characteristics and traditions, "A strong government...is an effective self-governing of free people. This is the meaning of democracy and in this sense, of sovereign democracy." ${ }^{42}$ Shevtsova explains that the term is meant to express two key points - that Russia should have its own logic and manner of democracy and that there should be no external influence over Russia's domestic affairs, including democratization. ${ }^{43}$ In effect, a distinctly Russian form of democracy is portrayed as a fundamental aspect of Russian sovereignty. Naumov and Slonov argue, however, that this term is inappropriate because 'sovereign' is not an adjective that can be applied to political regime types, since it is the

\footnotetext{
${ }^{40}$ Aleksandr Dugin, "Souchastie, sobornost', samobytnost'," Argumenty i fakty, no. 16 (2006): 4.

${ }^{41}$ Interestingly, the website for United Russia no longer displays most of Surkov's speeches on sovereign democracy. For example, the links to his speeches from Wikipedia's "sovereign democracy" page no longer work, while internet searches of the titles of these speeches do not result in any matches. This could signal a shift away from the model of sovereign democracy under the new presidential administration.

${ }_{42}$ Author's translation of "Сильным государством я считаю эффективное самоуправление свободных людей. В этом смысл демократии и в этом смысл суверенной демократии." (Edinaia Rossiia, "Suverennaia demokratiia - eto effektivnoe samoupravlenie svobodnykh liudei," Edinaia Rossiia ofitsial'nyi sait partii, http://old.edinros.ru/print.html?id=120750.)

${ }^{43}$ Shevtsova, Russia - Lost in Transition, 75.
} 
state that is sovereign, not the style of government. ${ }^{44}$ Instead, they argue that the term "sovereign civilization" (suverennaia tsivilizatsiia) is more appropriate, since 'civilization' shows that Russia is inherently different from Europe, but also equal. ${ }^{45}$

Interestingly, Naumov and Slonov note that Russia's style of government should be called sovereign democracy to an English speaking audience, ${ }^{46}$ presumably because the term corresponds with western terminology, where 'democracy' implies 'legitimate government,' or because the term 'civilization' might make the West uncomfortable in regards to how Russia is positioning itself in the world. In addition, the authors are critical of a western template for Russia, arguing against their country following the model of American democracy, since it is really a 'democracy of money,' where those who have the most money and control the most market shares have the most power. Adherence to this format, as during the Yeltsin years, did not benefit the people of Russia and did not create a system that could be characterized as democratic. ${ }^{47}$ Rather, the authors suggest that Russia should follow its own democratic course via a sovereign civilization, which will lead to the best conditions for Russian citizens.

Viacheslav Morozov's article on Putin's regime and sovereign democracy, "Sovereign democracy in a post-sovereign world: Putin's restoration as conservative modernization," also shows the influence of Eurasianist thought. He notes that liberal values are "inorganic" to Russian society; something imposed on Russia by western

\footnotetext{
${ }^{44}$ Sergei Naumov and Nikolai Slonov, "Suverennaia demokratiia: Eshche raz k voprosu o termine," Svobodnaia mysl' 1574, no. 3 (2007): 22.

${ }^{45}$ Ibid., 28.

${ }^{46}$ Ibid., 30.

${ }^{47}$ Ibid., 25.
} 
countries to deprive the nation of its identity ${ }^{48}$ Morozov argues against liberalism for Russia and believes that the anti-liberal measures undertaken by Putin will provide for freedom through restoring Russia to a great state based on a common will of national self-realization. ${ }^{49}$ However, Morozov is not overly supportive of the term sovereign democracy to classify Russia's regime, since he regards it as a "name-game" used to appease the West while still rejecting liberalism; however, he does note that reflecting on sovereign democracy is a useful starting point for understanding Putin's style of administration. Instead, he terms Putin's regime as one of conservative modernization (reaktsionnaia modernizatsiia), which echoes Vitushkin's terminology of rightconservatism.

Also fitting into the major trend in the Russian scholarship on democracy and democratization during Putin's tenure as president are those works that provide general defences of Putin's policies, arguing that he is leading Russia toward democracy. Alexey Pushkov evaluates Russia after Putin's first term as president positively, positing that he acted as an 'authoritarian modernizer. ${ }^{50}$ He notes that although Putin prioritized economic and social reforms over the development of democratic institutions, he is far from being a "Russian version of Pinochet." ${ }^{, 51}$ Instead, he believes that Putin's policies, meant to modernize Russia, are a precursor to political democratization. A novel argument put forth by Pushkov is that the main domestic opposition to Putin comes from individuals who identify themselves with previous governments and have since found

\footnotetext{
${ }^{48}$ Viacheslav Morozov, "Suverennaia demokratiia v postsuverennom mire: putinskaia restavratsiia kak reaktsionnaia modernizatsiia," Heprikosnovennyi zapas 50, no. 6 (2006), http://magazines.russ.ru/nz/2006/50/mo9.html.

${ }^{49}$ Ibid.

${ }^{50}$ Alexey Pushkov, "Putin at the helm," in Chaillot Paper n. 74: What Russia Sees, ed. Dov Lynch (Paris: Institute for Security Studies, 2005), 60.

${ }^{51}$ Ibid., 58-59.
} 
themselves marginalized from power (such as communists, liberal reformers of the 1990s, and some oligarchs). These people unite in opposition to Putin under the "banner of democracy,' even though, "The real goal of its leaders is not to bring democracy to Russia but to use democracy as a slogan against Putin's rule. ${ }^{, 52}$ It is curious that Pushkov would try to discredit Putin's opposition in order to prove that Putin is improving Russia, rather than pointing out concrete examples of how the opposition is mistaken.

Another Russian who writes positively about Putin's rule is Andranik Migranyan, who states, "If democracy is the rule by a majority and the protection of the rights and opportunities of a minority, the current political regime [of 2004] can be described as democratic, at least formally.",53 In, "What is Putinism?" Migranyan defends the policies of Putin, suggesting that there has not been a decline in democracy in Russia because Russia was never democratic to begin with. He writes that under Yeltsin, there was an 'illusion of democracy,' since the state lost a significant amount of its power and authority, but that this illusion only hid the chaos and corruption to outside observers. ${ }^{54}$ He further criticises Yeltsin and his administration for failing to nurture the foundations of a democratic regime, namely political parties and institutions to support civil society. ${ }^{55}$ Since Putin took control of a decentralized state with very little authority over its population, Migranyan praises Putin for his role in restoring governance, stability, and lawfulness within Russia by creating a 'hierarchy of power. ${ }^{56}$ Thus, the heart of Migranyan's argument is that Putin's policies, which may seem authoritarian in nature,

\footnotetext{
${ }^{52}$ Pushkov, "Putin at the helm," 60.

${ }^{53}$ Andranik Migranyan, "What is Putinism?" Russia in Global Affairs 2, no. 2 (2004): 39.

${ }^{54}$ Ibid., 32.

${ }^{55}$ Ibid., 34.

${ }^{56}$ Ibid., 34.
} 
are actually meant to fix problems within Russia, so that the country will be able to consolidate democracy in the future. In essence, Migranyan suggests that Putin is actually moving Russia closer to democracy.

In "Democratic Transformations and the Unsuccessful Democratic Transition of Russia," N.V. Nalivkina diverges from the previous two arguments, suggesting that Putin is moving Russia toward democracy, though his regime is not currently democratic. Nalivkina classifies Putin's regime as one of 'soft authoritarianism' (miagkii avtoritarizm). Although she never explicitly defines this term, her agreement with Valerie Bunce's position ${ }^{57}$ that the Russian system is a balance between democracy and dictatorship and between capitalist and socialist economic policies suggests that this is what she means by soft authoritarianism. ${ }^{58}$ Nalivkina purports that although soft authoritarianism is capable of either moving gradually toward democracy or toward 'hard' (or full) authoritarianism, Russia will likely move toward the former since a more severe form of authoritarianism is at odds with the needs of society and the aspirations of Russians, who have "felt independence and the taste of freedom." although Nalivkina does not explicitly state that Russia is on course to its own version of a democratic system, she does caution that there cannot be a single standard of democracy, nor should democracy be viewed as a system that appears at immediately or

${ }^{57}$ In "The Political Economy of Postsocialism," Bunce examines the political and economic variations within the Former Soviet Union and Eastern Europe and determines that the states, which now populate this region, fall into one of three categories: capitalist-democratic, semisocialist-authoritarian, or the "middle ground" between these extremes. Bunce exemplifies Russia as a "middle ground" state, since it is characterized by a political and economic system that produces few benefits for the general population, while costing them a lot (The Slavic Review 58, no. 4 (1999): 761 \& 786).

${ }^{58}$ N.V. Nalivkina, "Demokraticheskie perekhody i neudacha demokraticheskogo tranzita Rossii," Vestnik TGPU (Tomskii gosudarstvennyi pedagogicheskii universitet) 12, no. 63 (2006): 85.

${ }^{59}$ Author's translation of “...ощутивших самостоятельность и вкус свободы.” (Nalivkina, "Demokraticheskie perekhody," 87.) 
through a fixed set of sequences. ${ }^{60}$ Nalivkina concludes that Putin's style of rule is the best option for Russia right now, given the political climate of societal longing for political stability and since she believes this form of rule is most appropriate for Russia's native traditions and historical experiences. ${ }^{61}$

In the western literature reviewed, there is some work that reflects the position that Russia is not backtracking or reversing democratic gains; however, unlike in the Russian literature, there is less of an emphasis on Putin doing things correctly than on the fact that transitions to democracy are neither quick nor easy. In A Normal Country: Russia after Communism, Andrei Shleifer chronicles Russia's reforms, beginning with the period of glasnost and perestroika. He argues that the economic reforms aimed at transforming Russia from a broken communist state into a modern, market-driven state have been largely successful and thus, Russia is now a 'normal' country. He purports, “...although Russia's transition has been painful in many ways and its economic and political systems remain far from perfect, the country has made remarkable economic and social progress. Russia's remaining defects are typical of countries at its level of economic development."62 The crux of his argument is that the western world misconceived the level of Russia's economic development at the time of the dissolution of the Soviet Union, which then led to disappointment when corruption, inequality, and a 'democracy' unreflective of that in the West took hold. Instead, Shleifer suggest that these traits are normal for 'middle-income' countries like Russia, Argentina, and South

${ }^{60}$ Nalivkina, "Demokraticheskie perekhody," 85-86.

${ }^{61}$ Ibid., 87.

${ }^{62}$ Andrei Shleifer, A Normal Country: Russia after Communism (Cambridge, Mass.: Harvard University Press, 2005), 157. 
Korea. $^{63}$ Shleifer's argument suggests that many of the critiques of Russia's policies and progress are premature and that Russia is actually doing a satisfactory job in democratizing. Unlike the other sources reviewed, A Normal Country focuses primarily on economics and thus, does not pay much attention to the effect of the president on democracy in Russia. As such, Shleifer does not put forth a clear position as to whether Putin is having a positive effect on democracy; only that Russia is on the right course.

Ellen Carnaghan also takes a different approach to the issue of Russia's democratic transition, employing in-depth interviews with open-ended questions to gain insight into how ordinary Russians feel about democracy and the democratic progress of their country. Using the results from these interviews, Carnaghan contradicts cultural arguments that suggest there is some sort of long-standing tradition or value intrinsic to Russians, which prevents them from accepting and supporting democratic practices. Despite the fact that many Russians act in a manner that exemplifies the notions of a tradition Russian political culture, she contends that such behaviour is not necessarily the result of an innate orientation to distrust the government, but rather a manifestation of how Russians are affected by their present social, political, and economic conditions. ${ }^{64}$ Carnaghan suggests that the citizens' preferences are not causing Russia to be undemocratic; however, the principal preference of Russians is for order in society, which may but not necessarily come at the expense of democracy. Furthermore, Carnaghan discovers that widespread disillusionment with democracy is a reflection of how this system of governance is malfunctioning in Russia, and not a dislike of the concept itself, as most citizens would prefer to see democratic institutions improved, not

\footnotetext{
${ }^{63}$ Shleifer, A Normal Country, 157.

${ }^{64}$ Ellen Carnaghan, Out of Order: Russian Political Values in an Imperfect World (University Park, Penn.: The Pennsylvania State University Press, 2007), 280.
} 
discarded. ${ }^{65}$ However, Russians tend to support the "creeping authoritarianism" of the Putin regime because Putin seems to be correcting the problems created by Yeltsin. By limiting the freedom and taking property from the very rich, Putin is perceived to be founding a political and economic system that could be in the best interests of ordinary people. ${ }^{66}$ Although Out of Order does not address how to classify Putin's regime, nor the government's role in moving Russia toward or away from democratic ends, it does lend support to the arguments put forth by the Russians who support Putin and assess their country's trajectory in a positive way by showing that regular Russian citizens desire Putin's policies to bring stability and order to the country as a precursor to a more full form of democracy.

What emerges?

The literature reviewed was divided into two groups-western and Russian-in order to highlight the differences in how academics from the different regions view Russia's political situation under Putin and the country's democratization. For the most part, the western books and articles took a critical stance toward Putin and his administration or contained arguments that the country was not democratic. Having read numerous times about Putin's supposed crackdown on dissidents in such sources, I was surprised to read articles by Russian scholars in Russian journals that argue a similar point and are highly critical of their country's governing. Nevertheless, such viewpoints were a minority in the reviewed Russian scholarship. Furthermore, a number of the Russian articles that suggest Russia is an authoritarian state temper such criticism by

${ }_{65}^{65}$ Carnaghan, Out of Order, 8.

${ }^{66}$ Ibid., 9. 
purporting that this type of rule is to bring stability to society, which will allow for greater democratization in the future.

Despite the fact that this literature review was only able to scratch the surface of the numerous works on democratization in Russia, a few trends do emerge. The first is the agreement across both the western and Russian sets of literature that Russia is not a liberal democracy, nor currently headed toward being one. In much of the western literature, this viewpoint is presented by showing how Russia has failed to live up to a liberal democratic standard and, when facts show a regression in particular aspects of how a liberal democratic state should function under Putin compared to under Yeltsin, this evidence is used to show that Russia is moving away from democracy. Many of the reviewed works from the Russian literature suggest that liberalism is an ideology unsuitable for Russian culture, while nearly all of them, including articles critical of the Putin administration's actions, suggest that Russia should not follow a western model of democratization. However, few of the Russian articles provide a clear alternative to such a model. The only exception is the idea of right-conservatism, which provides a philosophical underpinning for Putin's style of rule. In some of the Russian literature and, to a lesser extent, in the western literature, the idea that Russia is moving toward a form of democracy or at least that Putin is creating the conditions that will allow for this is present. Interestingly, all the sources from the western literature that suggest Russia is backsliding democratically could be classified in the field of political science, while the two reviewed western sources that provided support for Putin's policies are from other disciplines within the social sciences (economics and anthropology). 
Another idea common to both sets of literature is that a democratic system is desirable aim for Russia. Although liberalism was often rejected in the Russian literature, the idea of democracy itself was never rejected and, in fact, was sometimes recommended. This does not suggest that no one in Russia would prefer a different system, but rather that within the reviewed literature, there seems to be a general acceptance that Russia should be a democracy. However, there is a marked difference between literature sets as to what constitutes the best form of democracy for Russia. Whereas the western literature suggests that a liberal democratic state should be Russia's aim, the Russian literature lends support to the idea of a different form of democracy that better suits the country's history and culture, often suggesting a conservative form of democracy, which supports the ideas of community, nationalism, and moral standards. Interestingly, nowhere in the western literature was the idea of 'right-conservatism' as a democratic possibility present.

Connected to the split in the type of democracy that Russia should seek is a division in what is perceived to be in the immediate best interests of Russia. The western literature, which condemns Putin's actions, seems to emphasize the necessity of openness and minimal government intervention in society, though it never satisfactorily explains why these should be the most important aims of the government. Rather, there is an assumption that because these aspects are integral to liberal democracy and areas where Russia lags, they are the most necessary aspects to change, as, presumably, the more quickly Russia can become democratic, the better off it will be. The Russian literature, on the other hand, bases its assumptions of the most important aims for the government on fixing problems created by Russia's initial democratization policies and, in particular, 
in creating order and stability. In this sense, democratization is not seen as an immediate priority for the government, although it is often mentioned as step that could follow political stabilization and the creation of order.

Another notable trend in the literature is the polarity in opinions. Overall, it seems that both western and Russian scholars are either critics or apologists of Putin, with very few moderate opinions in between. This lack of balance is present in examinations of various policy initiatives of the Putin administration, where either only the negative effects or positive effects are discussed. A clear example of this is in the debate surrounding the Putin's efforts to control the regions of Russia. McFaul, Petrov, and Ryabov write:

In the 1990s, governors of oblasts and presidents of republics acquired genuine political autonomy when power in Moscow evaporated. To reassert Moscow's dominance, Putin started by creating seven new supraregional executive authorities whose mandate is to enforce Putin's policies at the regional level. He then emasculated the Federal Council, Russia's closest approximation to the U.S. Senate, by removing governors and heads of regional parliaments from this upper chamber. Formally, each regional executive appoints one representative to the Federal Council and each regional legislature appoints one representative to the upper house. Informally, the Kremlin has exercised considerable influence in shaping the selection of these representatives, effectively making this parliamentary body a rubber stamp for Kremlin policies. ${ }^{67}$

This assessment of Putin's actions towards Russia's regions suggests that the only purpose of such behaviour was to give Putin more power to satisfy his personal interests. Pushkov, on the other hand, notes similar actions, but as a response to "the growing regionalisation of the country," which was leading Russia toward collapse or

${ }^{67}$ McFaul, Petrov, and Ryabov, Between Dictatorship and Democracy, 294-295. 
disintegration. ${ }^{68}$ Although Pushkov notes that the result of Putin's reforms was that the Federal Council no longer has a significant effect of Russian political life, he believes the trade-off between this and restricting the regions from seeking greater autonomy was well worth it. ${ }^{69}$ Another example of differing opinions regarding particular policies is in relation to rules regulating civil society. Whereas Balzer notes, "The government also retains multiple levers to use in regulating and disciplining NGOs [non-governmental organizations], including registration requirements and the option of ignoring abuses by "excessively zealous" local officials,", Morozov suggests that the Law on Public Associations, (which created the registration requirements for NGOs), cannot be interpreted as a measure specifically aimed at the suppression of civil society because it is an attempt to ensure the autonomy of Russia's internal political sphere from external interference. ${ }^{71}$ It appears that in macro level examinations of Russian democracy, very few sources examine policy initiatives from multiple angles. Rather, the authors tend to highlight only the outcomes that support their particular view on the issue.

By looking at the case of Russia's democracy from both western and Russian perspectives, it becomes apparent that there is incongruence in the conception of democracy. The transition to a democratic system of governance is viewed differently from inside a democratizing state than it is by the West and, as such, we must modify our understanding and expectations of democracy if we are to fully understand regime transitions. While there seems to be an assumption in the West that liberal democracy is transplantable to other countries as long as those countries modify their political and

\footnotetext{
${ }^{68}$ Pushkov, "Putin at the helm," 50.

${ }^{69}$ Ibid., 50.

${ }^{70}$ Balzer, "Managed Pluralism," 207.

71 Morozov, "Suverennaia demokratiia v postsuverennom mire."
} 
economic systems to match those in the West, as demonstrated through analyses of "what went wrong" in Russia rather than acceptance that Russia may choose its own path, Russian authors, for the most part, reject western opinions of how their country should operate. Although still supportive of democracy, Russians desire it in a form of their own—one that suits the 'Russian civilization.' This is not a claim that should be easily dismissed by the West. Even if the language of Russia's distinctiveness is disagreeable to the West, the assertion that Russia is interested in democracy should be taken seriously. This means that we need to reconcile the split between western prescriptions for democratic transitions and Russian understandings of what kind of democracy would best suit their country. This then brings us to the main task of this thesis project: to think about democracy differently, so that it would be a suitable political system for Russia (or any other country) while still maintaining its core meaning and value. 


\section{Chapter 2: An Overview of Democratic Theory}

Any study of democracy necessitates a look at the term itself for two major reasons: to define a key concept of the paper and to review existing literature on the topic. This chapter will attempt the second, while only touching upon the first, vis-à-vis the definitions of democracy according to particular political philosophers. The subsequent chapter will continue exploring definitions of democracy and will provide the definition of democracy to be used in this thesis. It is my hope that these chapters will provide the theoretical groundwork necessary for understanding democracy and the logic for the definition I apply in this thesis. This chapter then, will first examine what I have termed the 'essence' of democracy—-the fundamental nature of the term-and then review (in close-to-chronological order) some of the major historical works that developed the field of democratic theory. The final part of this chapter examines the works of a few modern democratic theorists in order to present the current divisions in how to define democracy.

\section{The Essence of Democracy}

The differing meanings and understandings of democracy create varying assumptions and expectations for what democratization should entail, and what should be its result. After reviewing literature that explores the meaning of democracy, it appears that most theories fit into one of two camps: what I have defined as democracy as a system or as an archetype. Democracy as a system refers to a set of institutions and norms that best allow for the core values of democracy to be practiced in the real world. As an archetype, democracy would be an ideal of societal organization in which all citizens participate equally in the decision-making processes of their government. 
However, since it is a perfect model, governments may strive to meet its definition, but would always fall short, thus constraining democracy to the realm of theory. In contrast to these two camps, I propose that democracy should be thought of in a third manner-as a set of normative underpinnings that guide society, but may be manifest in a variety of institutions and practices. The normative keystones that $\mathrm{I}$ have identified are popular control of government, political equality, and freedom.

By popular rule, I am referring to a system of governance whereby most people in society are permitted to participate in the governing of their state. As Jack Lively remarks, this can take a number of different forms, as 'rule of the people' can be interpreted in the following ways: that every citizen should be involved in all aspects of governing (legislating, policy setting, applying laws, and administration); that all citizens should be directly involved in making vital governmental decisions; that the governors should be answerable to the governed and thus justify their decisions and actions or face the threat of removal; that the governors should be accountable to representatives of the governed; that governors should be chosen by those they govern; that governors should be chosen by representatives of the governed; and that governors should act in the interests of the governed. ${ }^{1}$ Political equality can encompass a number of features-that all citizens share the same political rights, that their opinions are counted equally during an election, and "...that every citizen is equally entitled to be considered part of the national community whose will the political elite articulates..."2_-but essentially comes down to the idea that no individual or group of individuals has any political privileges or a benefitted status in society that the majority of citizens do not have access to enjoy.

\footnotetext{
1 Jack Lively, Democracy (Oxford: Basil Blackwell, 1975), 30.

${ }^{2}$ Richard S. Katz, Democracy and Elections (Oxford: Oxford University Press, 1997), 101.
} 
The term freedom could be understood in a number of different ways. For example, David Held suggests the 'principle of autonomy' implies the freedom and equality of citizens in considering and making decisions about their own lives (selfgoverning), as long as such deliberations and decisions do not counteract the freedom or equality of others. ${ }^{3}$ Similarly, Robert Dahl also discusses autonomy in a similar way, noting three different ways in which freedom has been put forth as an aim of democracy: as the assurance of particular rights and opportunities necessary for the operation of democracy; as a form of self-determination, allowing individuals to govern themselves through obeying legal regulations that they have selected for themselves; and as 'moral autonomy,' which implies individual freedom when making decisions related to one's private affairs. ${ }^{4}$ Thus, freedom can be understood in relation to the individual-as a person's right to self-govern. However, freedom can also be understood on a collective basis. By this, I am referring to the freedom of citizens from any other rule but their own - the right of the group to self-govern. The second section of this chapter, which traces the development of democratic theory, illustrates how I determined these three elements to be the 'essence' of democracy. If democracy is to be the perfect attainment of popular control of government, equality and freedom/autonomy, then, as stated earlier, this form of government would be impossible to achieve under real world conditions, because economic, intellectual, and social differences (to name only a few of the uncontrollable factors that affect humans on a daily basis) inevitably result in different levels of ability to participate in political life.

\footnotetext{
${ }^{3}$ David Held, Models of Democracy, 3rd Edition (Stanford: Stanford University Press, 2006), 264.

${ }^{4}$ Robert A. Dahl, Democracy and its Critics (New Delhi: Orient Longman Limited, 1991), 89-91.
} 
Jean Grugel also notes a problem with too utopian of an understanding of democracy in that it would exclude established and accepted "democracies" of our world from being considered as such. ${ }^{5}$ On one hand, Grugel makes a valid point that when defining democracy, we should not exclude systems that, overall, are considered democratic. If democracy becomes a concept completely removed from reality, it becomes a meaningless term and therefore inapplicable to governments in making decisions and to political scientists in classifying regimes. However, the danger of taking Grugel's point too far is that, by trying to ensure that real world 'democracies' fit into any given definition of democracy, democracy then becomes a concept specifically tailored to the western world. Grugel herself notes this problem in empirical democratic theory, which infers its core conception of democracy from an ideal model of the functioning of western politics, thereby reducing democracy to be the system that is thought to be present in the West. ${ }^{6}$ Furthermore, it is important to recognize that western democratic systems have yet to achieve the perfect ideal of democracy and, by basing a definition of democracy on that which exists in the West, it may obscure or gloss over the imperfections of western democracy. This sort of mentality contributes to a case of the 'pot calling the kettle black,' whereby western governments criticize other governments for being undemocratic, while ignoring their own democratic deficits.

Another point relevant to the discussion of democracy as a concept or a system is brought up by Robert Dahl. If democracy is to be understood as both an ideal and as an attainable state of affairs, he questions when then a regime is sufficiently proximate to the

\footnotetext{
${ }^{5}$ Jean Grugel, Democratization: A Critical Introduction (New York: Palgrave Macmillan, 2002), 5.

${ }^{6}$ Ibid., 21.
} 
ideal that it should be properly thought of as a democracy. ${ }^{7}$ Dahl's answer to this problem is to set a threshold level of requirements (a particular set of political institutions), that when surpassed, qualify the country as a 'polyarchy. ${ }^{, 8}$ He uses the term polyarchy specifically to distinguish democracy as a system from the ideal version. The set of institutions required include the extension of citizenship to a relatively high proportion of adults in a country, the opportunity for citizens to oppose and remove the highest level of government officials, the election of officials in free and fair contests, inclusive suffrage, the right to run for office, freedom of expression, access to a variety of opinions and information, and associational autonomy. ${ }^{9}$ Interestingly, Dahl acknowledges that the polyarchic system is limited in its global applicability; that short of a major international catastrophe (such as nuclear war or economic collapse), polyarchy will continue only in a core group of countries, where democratic institutions have existed for over a generation. On the margins of this core, there will be transformations toward or away from polyarchy, but it is unlikely that a new stable polyarchy will emerge. ${ }^{10}$

Jack Lively purports that since classical definitions of democracy do not match 'real world' conditions, a new definition of democracy is required, one that will suit the actual features of modern democratic life. ${ }^{11}$ Lively suggests that the only way to determine which countries should be considered democratic is to hold them against a stipulated definition of democracy, which precedes and does not flow out of empirical examination. ${ }^{12}$ It is possible that by requiring this, Lively aims to remove the problem of

\footnotetext{
${ }^{7}$ Dahl, Democracy and its Critics, 6.

${ }^{8}$ Ibid., 117.

${ }^{9}$ Ibid., 220-221.

${ }^{10}$ Ibid., 315.

${ }^{11}$ Lively, Democracy, 76.

${ }^{12}$ Ibid., 76.
} 
having democracy as a system modeled after the West. However, this is not so, as this approach has similar implications to that of Dahl's model. What Lively requires-setting criteria for democracy not based on empirical observations-is impossible because choosing criteria for real world conditions necessarily requires examining how democracy functions under those conditions or, at the very least, looking at what has been tried and what has been successful in terms of creating a democratic society. If the criteria are set completely removed from the reality of how democracies operate, then this definition of democracy will be as useless as the classical definitions that he dismisses. Thus, in the end, Lively's call for a redefinition of democracy - to be a system rather than an ideal - will end up being based to some degree on already existing democracies. As a result, democracy as a system will still be based on a western model.

It seems that to conceive of democracy either as an archetype or as a system are both problematic. A perfect democracy is impossible to achieve in reality, which seemingly necessitates a conception of democracy as a system-something that comes sufficiently close to the ideals of democracy, but that is actually a set of criteria used to determine which systems fall into the democratic camp. The result of this approach is that democracy becomes a particularly western system, founded on the principles of existing democracies. The problem of this lies in the fact that democracy has come to be seen as something universally desirable, as explained by Amartya Sen:

While democracy is not yet universally practiced, nor indeed uniformly accepted, in the general climate of world opinion, democratic governance has now achieved the status of being taken to be generally right. The ball is very much in the court of those who want to rubbish democracy to provide justification for that rejection. ${ }^{13}$

\footnotetext{
${ }^{13}$ Amartya Sen, "Democracy as a Universal Value," Journal of Democracy 10, no. 3 (1999): 5.
} 
If democracy is meant to be a universal system of governance, then there is an inherent contradiction between this and its strong western bias. Since many parts of the world have cultures and values that are seemingly very un-western in form, how are these cultures supposed to take on democracy without losing their own traditions or adopting western practices and values, which seem to go hand-in-hand with democracy?

To resolve this incongruity, I propose that, in the dichotomy between democracy as an ideal and as a system, democracy should be thought of as an ideal because this emphasizes that no actual democracy is perfect and will allow for a greater diversity in how democracy is put into practice, thus overcoming the regional specificities of current 'democracy-as-a-system' definitions. If democracy is an ideal, it does not come bound with a set of institutions that are "required" for a country to be democratic, which therefore makes it more adaptable to localized customs and traditions. However, rather than thinking of democracy in a utopian sense, by suggesting democracy is an ideal, I mean to imply that it is a theoretical underpinning for a governance system. Democracy should be a principle around which an unprescribed system of institutions is based. As long as a government and society subscribe to the core elements of democracy, this polity should be considered democratic, no matter if its institutions do not match those common to western states. To accommodate this understanding of democracy, the term must be defined in such a way so that it will be applicable to all variants of democracy (i.e. liberal and social) and a variety of manifestations of democracy in practice. The simplest way to do this would be to define democracy as "rule of the people" as is often done; however, this definition is not descriptive enough for it to be meaningful. (Who are the people? What are they ruling? How do they rule? ) The purpose of this thesis then is to find a 
definition of democracy as a theoretical underpinning that is more descriptive than popular rule, but does not only apply to western nations.

\section{The Development of Democracy}

In order to determine the major elements of democracy—the key ideas that are present in most, if not all, democratic theories-it is necessary to look at the history and development of democracy. Because the breadth of democratic theories is so wide, I will rely primarily on a synthesis completed by David Held, who, in Models of Democracy highlights the major developments of democratic theory. Although not exhaustive, my brief overview of the history of democracy should provide the reader with enough background information to understand the elements of democracy relevant to this thesis project; namely, the core values of democracy, the development of liberalism, and the notion of the general will. Held's book has been selected as the starting point for this discussion, since he covers an enormous body of literature (certainly more than could have feasibly been read for this project) and provides a useful set of categorizations and links between philosophers to help focus one's attention to the major aspects and developments of democracy.

Democracy, as the etymology of the word suggests, originated in Greece. In particular, democracy is thought to have originated in the city-state of Athens. ${ }^{14}$ Although there is no succinct explanation available of the inner workings of Athenian democracy, one of our best sources is Pericles' funeral oration in The History of the Peloponnesian War, written by Thucydides. Pericles declared that, "Our constitution is called a democracy because power is in the hands not of a minority but of the whole people," and spoke of equality before the law, ability (as opposed to class) as the key

\footnotetext{
${ }^{14}$ Held, Models of Democracy, 13.
} 
factor in obtaining political power, freedom and tolerance, upholding the law, citizens' interest in the state's affairs, including their active participation, and public debate of policy. ${ }^{15}$ Aristotle, another Athenian, defines liberty as "ruling and being ruled in turn" and "living as one chooses." 16 In these two ideas, it is possible to see how integral liberty has been to democratic ideas since the birth of democracy. Although Aristotle thought poorly of democracy, believing it to be the 'rule of the rabble,' that is, in the interests of the poorer classes in society, ${ }^{17}$ his understanding of liberty has been adopted, mutated, and transformed into elements intimately connected to conceptions of democracy today, including personal freedoms and participation in the governing of society. It would appear then, that the original conception of democracy emphasises the participation of the citizenry in governing, freedom, and, equality between citizens.

Held notes that Christianity had a great impact on Europe and, by extension, democracy. Namely, Christianity changed the source of authority and wisdom in society from citizens (according to the Ancient Greek notions of democracy and "philosopher kings') to God. ${ }^{18}$ Historically, this coincides with the rise of monarchies and later, absolutism —and, subsequently, an abandonment of the idea of democracy. However, Saint Thomas Aquinas, although no advocate of democracy, did introduce an idea that would later play an important role in modern democracy. By suggesting that the monarch is not necessarily always correct, particularly if his action were to contradict the will of God, and that he should be held to the standards of the higher power, Aquinas essentially placed constraints on the monarch or, in other words, limited the power of the

\footnotetext{
${ }^{15}$ Thucydides, History of the Peloponnesian War (London: Penguin Books, 1954 and 1972), 145-147.

${ }^{16}$ Held, Models of Democracy, 16.

${ }^{17}$ Aristotle, The Politics of Aristotle (Oxford: Oxford University Press, 1958), 115.

${ }^{18}$ Held, Models of Democracy, 29.
} 
government. ${ }^{19}$ However, around the same time as Aquinas, a humanist variant of republicanism began to take shape. The work of Marsilius of Padua, who argues that the people or a majority of people should make laws by expressing their will at a general assembly, provides an example of this early strain of humanist-republicanism, since he believed that the ultimate source of political authority lies with the people and not a higher power. ${ }^{20}$ Although it is difficult to link the work of Aquinas with the major tenets of democracy, his notion that the sovereign is not always correct builds the foundation for later ideas of constraining authority and, if needed, removing leaders. The link between modern-day conceptions of democracy and the work of Marsilius is more easily recognizable, as he advocated for popular control of government through an assembly.

According to Held, the work of Machiavelli is representative of the classical republican strain and although there are some elements of democracy in his writings, it is difficult to consider him a democrat. In terms of democratic aspects to his work, Machiavelli preferred liberty to tyranny and believed that the basis of liberty involves disputes and differing opinions through which citizens can advocate on behalf of their interests. ${ }^{21}$ However, in The Discourses, Machiavelli notes that popular government can only survive for a short time before it deteriorates into anarchy. ${ }^{22}$ For Machiavelli, the best government is one with a constitution incorporating elements from different forms of government. He writes, "[Constructors of constitutions] have been convinced such a

\footnotetext{
${ }^{19}$ Held, Models of Democracy, 31.

${ }^{20}$ Ibid., 36-37.

${ }^{21}$ Ibid., 42.

${ }^{22}$ Niccolo Machiavelli, "The Discourses," in Classics of Moral and Political Theory, Third Edition, ed. Michael L. Morgan (Indianapolis, IN: Hackett Publishing Company, Inc., 2001), 472.
} 
constitution would be more solid and stable, would be preserved by checks and balances, there being present in the one city a monarch, an aristocracy, and a democracy.,"23

Nevertheless, Machiavelli is also known for The Prince, in which he provides a manual for a ruler to gain control of a polity, using rather tyrannical methods. Despite Machiavelli's preference for liberty, he doubted the feasibility of a free government during a state's foundation and therefore thought it necessary for a prince to assume complete power and impose his vision of society on the population to ensure order. ${ }^{24}$ Although The Discourses and The Prince seem at odds with each other, it is possible to connect them. A strong, even autocratic, leader is necessary during the initial stages of state building, but after consolidation of the state and the acceptance of the prince's rule, it is possible to introduce a more balanced form of government. In terms of the development of democratic theory, Machiavelli's major contributions are in recognizing that there is indeed a place for popular rule in government, albeit one tempered by monarchy and elites, in his advocacy on behalf of constitutions, and in presenting the possibility that an authoritarian leader could pave the way for a more democratic form of governance.

The other philosopher provided by Held as an example of the classical republican tradition is Jean Jacques Rousseau, who suggests a 'social contract' as a way to justify and understand government. The social contract is an underlying agreement in society that legitimizes political authority without taking away a person's liberty. Under a social contract, society's main objective is to achieve freedom through the general will, which will result in the common good. Rousseau explains what is meant by the "supreme good

\footnotetext{
${ }^{23}$ Machiavelli, "The Discourses," 473. In this quote, Machiavelli uses the term "city" because at that time in Europe, city-states were the main polity.

${ }^{24}$ Held, Models of Democracy, 42.
} 
of all," writing that it can be reduced to two major aspects, "liberty and equality; in liberty, because all private dependence subtracts so much force from the body of the State; in equality, because liberty cannot subsist without it." ${ }^{, 25}$ Thus, according to Rousseau, liberty and equality are intrinsically good for humans and interactions between them. The social contract comes into force when each person in a society puts him/herself and his/her power 'under the supreme direction of the general will' and as a group, each person becomes 'an indivisible part of the whole. ${ }^{, 26}$ Furthermore, Rousseau purports that "...the social compact gives to the body politic absolute command over the members of which it is formed; and it is this power, when directed by the general will, that bears...the name of "sovereignty.",27 This means that entering into the social contract and consenting to be ruled by the general will, members of the community will still be able to maintain their freedom. Citizens are only obliged to comply with laws that they have prescribed for themselves through the determination of the general will or, in other words, what all citizens believe is best for the safety and wellbeing of society (whether or not they realize that they believe this). ${ }^{28}$

To determine their laws, citizens come together to form a legislative assembly, which is tantamount to the state's authority, while the government is only the executor of the people's laws. As such, the government is legitimate only to the extent that it fulfills what has been determined to be the general will. ${ }^{29}$ Although Rousseau felt that truly

\footnotetext{
${ }^{25}$ Jean Jacques Rousseau, The Social Contract (New York: Hafner Publishing Co., 1947), 46.

${ }^{26}$ Ibid., 15.

${ }^{27}$ Ibid., 27.

${ }^{28}$ Rousseau suggests that the general will, which related to the common interest, exists inside each person and a majority of people will correctly perceive what it is (The Social Contract, 26). The minority, who believed that the general will was something different (due to the influence of private interests), were just mistaken in their assessment of it and actually also will what the majority willed (96).

${ }^{29}$ Held, Models of Democracy, $45-47$.
} 
democratic governments were unsuited to humans, ${ }^{30}$ only small states could operate with a republican government based on the general will, due to the nature and scope of direct popular participation necessary. ${ }^{31}$ Nevertheless, the overall theory of The Social Contract is in itself a form of democracy since the general will is one method through which citizens can control their government. Furthermore, Rousseau emphasizes liberty and equality as being important ends for society, which is characteristic to democratic theory.

At the same time as political philosophers were laying the theoretical framework for democracy, Europeans were being introduced to democratic principles in their daily lives. Pre-nineteenth century Europe had various forces at work, which helped to lay the foundation for democracy. Charles Tilly identifies these as: merchant oligarchies, which were essentially city-state level democracies; peasant communities, where community members rotated through posts based on lot or elections, held general assemblies, and had defined rights within the community; religious sects, where there was democracy within congregations; and revolutionary movements, which sought to change the monarchical status-quo. ${ }^{32}$ These factors contributed to a sort of general acclimatization of European populations to democratic practices. Furthermore, despite the work of the early humanists to define and understand society distinct from religion, spirituality continued to play an important role in Europe and, subsequently, in the development of democracy. The Protestant Reformation in the sixteenth century and the spread of Luther and Calvin's teachings led to an understanding of the person as an individual, which began to gain popularity. Along with the idea of the individual as a political actor, the notion that

\footnotetext{
${ }^{30}$ Rousseau writes, "If there were a nation of gods they might be governed by a democracy. So perfect a government will not agree with men" (The Social Contract, 60).

${ }^{31}$ Rousseau, The Social Contract, 58-59.

${ }^{32}$ Charles Tilly, Democracy (Cambridge: Cambridge University Press, 2007), 29.
} 
a person could be in control of his/her own destiny began to spread, which departed from the older notion that God is in sole control of what happens in one's life. ${ }^{33}$ This, the birth of individualism, laid the groundwork for liberalism and its connections to democracy.

One of the first political theorists to consider the individual as a political being was Thomas Hobbes, who like Rousseau, was concerned with reconciling political authority and the liberty of individuals. According to Hobbes, liberty is a 'right of nature' whereby, “...each man hath, to use his own power, as he will himself, for the preservation of his own nature; that is to say, of his own life; and consequently, of doing any thing, which in his own judgement, and reason, he shall conceive to be the aptest means thereunto."34 However, such a state would create unending violence, since every person could do as he/she pleased without concern for others. Therefore, Hobbes believed that as a 'general rule of reason,' everyone should strive for peace by willingly forfeiting their 'rights to all things' and instead be satisfied with as much liberty towards others, as they would allow others towards themselves. ${ }^{35}$ For Hobbes, the best situation to achieve this security of person (in addition to protection from the invasion of foreigners) would be by citizens transferring all their power to one individual (or group), which would reduce their varied opinions and interests to one will. ${ }^{36}$ By this action, the people would create the conditions for security, peace, and a functioning political order. ${ }^{37}$ A similar idea is present in The Social Contract by Rousseau, who, no doubt, was influenced by Hobbes' Leviathan, even though Rousseau modified the idea of the people

\footnotetext{
${ }^{33}$ Held, Models of Democracy, 58.

34 Thomas Hobbes, "Leviathan," in Classics of Moral and Political Theory, Third Edition, ed. Michael L. Morgan (Indianapolis, IN: Hackett Publishing Company, Inc., 2001), 533.

${ }^{35}$ Ibid., 534.

${ }^{36}$ Ibid., 547.

${ }^{37}$ Held, Models of Democracy, 61.
} 
empowering a sovereign to the people being sovereign. Although Hobbes defends the notion of the ruler's absolute authority, he does lay the groundwork for future democrats in his interpretation of the agreement to form a commonwealth. By submitting to the rule of the sovereign, the people are actually submitting to their own rules since, according to Hobbes, the people have authorized the sovereign's actions and decisions and thus, “...have made themselves everyone the author [of laws]..." 38 In Hobbes' work, we see then the beginnings of the idea of popular governing through consent to a leader and the importance of the preservation of individual liberty, so long as it does not cause harm to others.

Developing out of Hobbes' work was that of John Locke, one of the foremost theorists of liberalism. Like Hobbes, Locke begins his Second Treatise of Government by examining the state of nature. According to Locke, in this state, humans are equal and independent and, through the ability to reason, know that it is wrong to harm others, their freedom, or their possessions. ${ }^{39}$ However, when men come into conflict with one another or try to bring others under their control, they leave the state of nature and enter the state of war. The only way to escape this state and have protection of one's property is by entering into society. ${ }^{40}$ When a group of people decide to enter into society together, they thus authorize the society to make laws on their behalf for the good of the public. ${ }^{41}$ According to Locke, the government's purpose in society then is to defend the property (life, liberty, and estate) of its citizens; or in other words, to protect individual rights. ${ }^{42}$

\footnotetext{
${ }^{38}$ Hobbes, "Leviathan," 548.

39 John Locke. "Second Treatise of Government," in Classics of Moral and Political Theory, Third Edition, ed. Michael L. Morgan (Indianapolis, IN: Hackett Publishing Company, Inc., 2001), 626.

${ }^{40}$ Ibid., 630.

${ }^{41}$ Ibid., 648.

${ }^{42}$ Ibid., 647.
} 
Locke believed that individuals are the best judges of their own interests; so consequently, democratic governments should be restricted in their authority and scope of power, which would grant citizens as much freedom as possible to determine their own ends. ${ }^{43}$ As such, the liberty of citizens is of prime importance in society. Locke writes:

But freedom of men under government, is, to have a standing rule to live by, common to every one of that society, and made by the legislative power erected in it; a liberty to follow my own will in all things, where the rule prescribes not; and not to be subject to the inconstant, uncertain, unknown, arbitrary will of another man: As freedom of nature is, to be under no other restraint but the law of nature. 4

In this quote, we see Locke's vision for society is one in which all citizens are equal (as the law applies equally to everyone) and that citizens have a high level of individual freedom (since they are only forbidden from action that has been explicitly outlawed). In terms of system of governance, Locke purported that a constitutional government with confined and divided political power is the best arrangement to ensure the liberty of individuals. $^{45}$ He writes:

...if [the people] have set limits to the duration of their legislative, and made this supreme power in any person, or assembly, only temporary; or else, when by the miscarriages of those in authority, it is forfeited; upon the forfeiture, or at the determination of the time set, it reverts to the society, and the people have a right to act as supreme, and continue the legislative in themselves; or erect a new form, or under the old form place it in new hands, as they think good. ${ }^{46}$

More simply put, Locke contends that the people should maintain control of their government. This vision of a democratic society is one that has resonated greatly with

\footnotetext{
${ }^{43}$ Held, Models of Democracy, 64.

${ }^{44}$ Locke, "Second Treatise of Government," 631.

${ }^{45}$ Held, Models of Democracy, 64.

${ }^{46}$ Locke, "Second Treatise on Government," 689.
} 
the western world, as we see in it elements that are often considered indispensible to democracy: the notions that the freedom of individuals is of primary concern in governing and thus, there should be a limited government, that all citizens are equally entitled to the rights of life, freedom, and property, and that the ultimate authority over government rests with citizens.

According to Held, the next political philosopher who advanced the liberal stream of democratic theory was Charles Louis II, Baron of Montesquieu. Montesquieu advocated on behalf of a constitutional government as the best means for guaranteeing the rights of individuals, since a state structure that is not controlled by one person is less susceptible to abusing the rights of citizens. ${ }^{47}$ However, in The Spirit of Laws, Montesquieu does not actually refer to individual rights per se, but rather to liberty. For example, when discussing the value of separating the government into distinct branches, he writes:

Again, there is no liberty, if the power of judging be not separated from the legislative and executive powers. Were it joined with the legislative, the life and liberty of the subject would be exposed to arbitrary control; for the judge would then be the legislator. Were it joined to the executive power, the judge might behave with all the violence of an oppressor. ${ }^{48}$

Although Held implicitly links the term liberty to individual rights, it does not match completely with Montesquieu's definition of the term, to whom “... liberty can consist only in the power of doing what we ought to will, and in not being constrained to do what we ought not to will....Liberty is a right of doing whatever the laws permit; and if a citizen could do what they forbid, he would no longer be possest of liberty, because all

\footnotetext{
${ }^{47}$ Held, Models of Democracy, 66.

${ }^{48}$ Montesquieu, The Spirit of Laws (Berkeley: University of California Press, 1977), 202.
} 
his fellow citizens would have the same power."49 Certainly, individual rights would facilitate people's ability to act as they wish, but Montesquieu's emphasis is on liberty as a freedom from threat, rather than unrestrained freedoms. ${ }^{50}$ Thus, for Montesquieu, liberty may not include what are today considered individual rights if such rights were not necessary for the security of citizens.

The Spirit of Laws is not in itself a set of democratic treatises, as Montesquieu examines democracies, monarchies, and despotisms equally, nor is his definition of a democracy- "When the body of the people in a republic are possessed of the supreme power..." democratic theory is in his support for and development of the ideas of an institutionalized separation of powers and checks and balances. This position would have a significant impact on the American 'Founding Fathers' and subsequently, become a cornerstone of western democracy. For example, In The Federalist, James Madison supports a form of popular rule in which the government would be held accountable to the citizenry through possible removal at regular intervals, a federal state structure, and a clear division of power between branches of government. ${ }^{52}$ Madison's opinion was that such an arrangement would nullify the dividing nature of factions, while at the same time, including citizens more directly in the governing of their country and thus preserving liberty. $^{53}$

\footnotetext{
${ }^{49}$ Montesquieu, The Spirit of Laws, 200.

${ }^{50}$ Ibid., 217.

${ }^{51}$ Ibid., 107.

${ }^{52}$ Alexander Hamilton, James Madison, and John Jay, The Federalist (Cleveland: The World Publishing Company, 1961).

${ }^{53}$ Held, Models of Democracy, 72.
} 
The final contribution to both democracy and liberalism that will be examined based on Held's assessment of the historical development of democratic theory is that of the utilitarian thinkers, Jeremy Bentham and James Mill. According to the theory of utilitarianism, the goal of any given society is to allow for the greatest happiness of the greatest number of citizens. More specifically, in the words of Mill, “... [the government's] business is to increase to the utmost the pleasures, and diminish to the utmost the pains, which men derive from one another." 54 Although, for example, Mill does not advocate on behalf of a republican form of democracy, preferring instead the British blend on monarchy, aristocracy, and democracy, ${ }^{55}$ in Held's opinion, the utilitarian thinkers did advance the ideas of liberal democracy. In examining the works of Bentham and Mill, Held suggests that liberal democracy became a political apparatus that would hold governors accountable to the governed through the introduction of the secret ballot during elections, competition between candidates for governmental positions, and the necessity of guaranteeing freedom of the press, freedom of speech, and freedom of public association. $^{56}$

Although by no means an exhaustive review of the early works of democratic theory, it is hoped that the previous review of the major streams of democratic theoryclassical, republican, and liberal-will be enough to ground the reader's understanding of democracy before examining modern (twentieth century) theories. Many of these theories continue the traditions already described, while others chart new paths. Within the modern literature, democracy is usually defined somewhere on a spectrum between a minimalist definition (which is generally understood as the regular holding of fair

\footnotetext{
${ }^{54}$ James Mill, An Essay on Government (Indianapolis: The Liberal Arts Press, Inc., 1955), 48.

${ }^{55}$ Ibid., 62.

${ }^{56}$ Held, Models of Democracy, 75.
} 
elections and the introduction of basic political principles and values that make such elections possible) to a more inclusive definition of the term (which includes liberal individual rights in its prerequisites or adds social and/or economic democracy to the political aspects of a minimalist definition). ${ }^{57}$ Another way to categorize democratic theories is presented by Charles Tilly. He groups definitions of democracy into four major groupings: constitutional definitions, which focus on the laws concerning political activity within a given regime; substantive definitions, which concentrate on the quality of citizens' lives based on government policies; procedural definitions, which look only at a small number of political processes to determine if the governmental system is democratic; and process-oriented definitions, which put forth a set of processes that must be in operation for a state to be considered democratic. ${ }^{58}$ Because of the wide range of modern democratic theories and models, at this point, I will focus only on a few that are representative of different types of definitions or positions along the spectrum.

Perhaps the most famous of the 'minimalist' or procedural democratic theorists is Joseph Schumpeter. In his opinion, the term democracy implies only that citizens are given the opportunity to accept or refuse in a free competitive election which candidates will govern them. ${ }^{59}$ In this sense, democracy becomes an apparatus to allow citizens some say in their governing while at the same time, transferring responsibility for the formation of public policy to those that are 'qualified' to make such decisions. ${ }^{60}$ Although Schumpeter does not go into detail about what qualifies one for such decisionmaking beyond availability to work in this faculty and 'adequate ability and moral

\footnotetext{
${ }^{57}$ Grugel, Democratization, 5.

${ }^{58}$ Tilly, Democracy, 7-9.

${ }^{59}$ Joseph A. Schumpeter, Capitalism, Socialism and Democracy (London: Unwin Paperbacks, 1987), 284285.

${ }^{60}$ Held, Models of Democracy, 143.
} 
character, ${ }^{61}$ such qualification may be explained by his notation that politics is career and as such, the politician's primary purpose is to focus on governing. ${ }^{62}$ Simply put, in this model of democracy, the citizens' role is to accept or refuse their leaders, which provides the necessary legitimacy to the governors and leaves the complexity of ruling a country to those that make it their career and chief concern. ${ }^{63}$

By reducing democracy to a basic mechanism for selecting leaders, Schumpeter's definition becomes void of most of the major elements of democracy seen in the work of the classical theorists, particularly those that are highly idealistic and difficult to achieve, such as equality and freedom. The ability to participate in elections does evoke the idea of popular rule, though the scope of the roles and responsibilities of citizens seems greatly reduced when compared to the original plans for popular participation. In fact, Schumpeter even goes so far as to suggest that voters should not instruct their leaders about how to do their jobs, nor should they 'informally' try to 'restrict the freedom of action' of their politicians by 'bombarding them' with written opinions and suggestions. ${ }^{64}$ A more moderate perspective along the spectrum comes from Charles Tilly, who defines democracy as the degree to which political relations between the state and its citizens feature broad, equal, protected, and mutually binding consultation. ${ }^{65}$ By breadth of consultation, Tilly is referring to the proportion of the state's population that has been provided with a wide range of rights, while equality refers to the similarity in allocation of rights and obligations among citizens. Protected consultation entails the degree to which citizens are sheltered from the random application of the state's force. By

${ }^{61}$ Schumpeter, Capitalism, Socialism and Democracy, 290.

${ }^{62}$ Ibid., 285.

${ }^{63}$ Held, Models of Democracy, 150.

${ }^{64}$ Schumpeter, Capitalism, Socialism and Democracy, 295.

${ }^{65}$ Tilly, Democracy, 13. 
mutually binding consultation, Tilly means the methods necessary for citizens to obtain state benefits, specifically whether there are unambiguous and enforceable requirements for the state to deliver benefits to its citizens (as opposed to providing benefits only to those who pay a bribe or hold a position of power). ${ }^{66}$ Tilly's conception of democracy focuses mainly on the principles of equality — in terms of the segment of the population awarded rights and in the distribution of these rights - and justice regarding the way in which the state interacts with its citizens. Interestingly, this definition of democracy does not refer directly to the idea of popular rule, nor to the idea of freedom. Instead, citizen participation in governing is accomplished through their consultation by the government in policy-making, while freedom is presumably part of the broad rights citizens should enjoy within a democracy.

At the other end of the spectrum is Amartya Sen's substantive definition of democracy. Sen rejects the notion that democracy can be equated with a majoritarian system since, "Democracy is a demanding system, and not just a mechanical condition (like majority rule) taken in isolation." ${ }^{, 67}$ Although Sen agrees that voting is an important part of democracy, he adds that it must also include the protection of liberties, respect for the law, and guaranteed free speech and communication, so that a plurality of perspectives and opinions have the opportunity to be voiced and discussed. ${ }^{68}$ This definition fits into Held's categorization of democracy as a continuation of the liberaldemocratic stream, as its emphasis is placed on protecting rights and liberties, so that citizens can enjoy a high quality of life, free from oppression. Furthermore, Sen's overriding concern for humans is their ultimate freedom, both from an oppressive state

\footnotetext{
${ }^{66}$ Tilly, Democracy, 14-15.

${ }^{67}$ Sen, "Democracy as a Universal Value," 10.

${ }^{68}$ Ibid., 10.
} 
and from poverty. As such, Sen believes that, “...political and civil freedoms are constitutive elements of human freedom,..." and are therefore necessary in a democracy. ${ }^{69}$ He stresses necessity of political and civil rights in allowing citizens to make contemplated and educated decisions when participating in the political process. ${ }^{70}$ According to Sen, these rights allow citizens to draw their government's attention to their needs and request a suitable response. ${ }^{71}$ It is this interaction-the citizen's demands and the state's appropriate response-which forms the democratic base of a society.

An example of a process-oriented definition is Dahl's concept of polyarchy. The features that Dahl deems necessary for a functioning polyarchic system were already described earlier in the chapter, but I mention his theory again since it would seem an oversight not to include polyarchy in a review of modern democratic theories and to better illustrate what Tilly means by a process-oriented definition of democracy. Although Dahl provides a list of institutions that should be present in a polyarchy, these conventions are actually symptoms of underlying democratic processes. According to Dahl, the four major processes that contribute to the degree of democracy in any political system are: effective participation, whereby all citizens have occasion to express their political preferences and influence their state's political agenda; equality between voters and between votes; ample opportunities for all citizens to seek out information to form and confirm their opinions on matters to be decided by election or referendum; and popular control of how issues are placed on the political agenda. ${ }^{72}$ It is within these processes then that we find the core elements of democracy. Popular rule is present in

\footnotetext{
${ }^{69}$ Amartya Sen, Development as Freedom (New York: Alfred A. Knopf, Inc., 1999), 16-17.

${ }^{70}$ Sen, "Democracy as a Universal Value," 10.

${ }^{71}$ Sen, Development as Freedom, 150.

${ }^{72}$ Dahl, Democracy and its Critics, 109-113.
} 
both the scope and types of the activities in which citizens should be involved (not only voting, but also agenda setting and participating in political discussion). Furthermore, Dahl's criteria emphasize equality between citizens themselves and their available opportunities. Although Dahl does not highlight freedom as a feature of democratic life, it is certainly necessary to achieve his criteria, particularly those of seeking information and expressing opinions.

In addition to these modern theories of democracy, which all seem to have a redefinition or refinement of the concept as their main purpose in order to make democracy more meaningful or relevant to modern society, there are a number of political scientists who select a more basic and non-controversial definition. For example, David Beetham defines democracy as the extent to which a system of collective decision-making is subordinate to the control of all members of the association and values popular control and political equality. ${ }^{73}$ Similarly, H.B. Mayo defines a democratic system as, “...one in which public policies are made, on a majority basis, by representatives subject to effective popular control at periodic elections which are conducted on the principle of political equality and under conditions of political freedom." 74 What is particularly noteworthy of these definitions is that they emphasise the same components that I have identified as the core elements of democracy. Since both Beetham and Mayo put forth such definitions after having extensively studied democratic theory, it seems safe to conclude that general opinion includes popular control and political equality are indispensible elements of democracy.

\footnotetext{
${ }^{73}$ David Beetham, Democracy and Human Rights (Cambridge: Polity Press, 1999), 4-5.

${ }^{74}$ H.B. Mayo, An Introduction to Democratic Theory (New York: Oxford University Press, 1960), 70.
} 
However, freedom and autonomy are not mentioned in as many definitions of democracy, though these ideas are present in many definitions. In some cases, the omission of freedom is likely because it is assumed to be present within a system in order for it to meet other conditions of democracy stipulated, as in Dahl's system of polyarchy. In others, like that put forth by Schumpeter, freedom is likely ignored because of its idealism, whereas Schumpeter attempts to define democracy in practical and realistic terms. However, even in this conception of democracy, there must be some degree of freedom, so that elections can be fair and voters can make informed choices because, without such conditions, elections would be meaningless and easily controlled by the government.

Throughout this chapter, there have been a number of different definitions of democracy presented. Running through them all are a few commonalities-popular control over the government, political equality, and freedom. Even within minimalist definitions, these core elements are present. Popular control is, perhaps, the key element of democracy, since by definition, it is 'the people' who rule the government. Political equality is an idea that has been attached to democracy since its genesis. Theoretically, if people are not equal to one another within the political sphere, it would be impossible for the "people" as a collective to rule, since those who are politically weaker would be excluded from ruling, thus making the government an oligarchy or aristocracy. Freedom is also at the core of democracy, since it reinforces political equality and provides a generally desirable state for humans. Which system of democracy then will best allow these core elements to flourish? This question will be the starting point for the next chapter. 


\section{Chapter 3: Liberal Democracy and an Alternative Definition}

The previous chapter ended with the question of which form of democracy best promotes and leads closest to the attainment of popular control of government, political equality amongst citizens, and freedom. The brief summaries of the democratic theories presented in the last chapter are, no doubt, their creators' opinions of the best form of democracy to achieve such ends. Of the modern definitions explored, those belonging to the liberal variant seem most popular; that is, those that emphasize elections and a preference for protecting individual rights as the best ways to ensure the liberty of citizens. My answer to the question of which conception of democracy is best suited for promoting the core elements of democracy, while at the same time, remaining general enough to not have a geographic bias, will come at the end of this chapter. Before that, there will be a look at the idea of liberal democracy, its components, and the problems with using it as the default definition of democracy. The second section contains a review of several other modern theories of democracy, which, unlike many of those in the previous chapter, try to define democracy in ways to suit non-liberal parts of the world.

\section{Liberal Democracy}

According to Richard S. Katz, "More than being a liberal theory of democracy, liberal democracy refers to attempts to find a democratic implementation of liberalism."1 This quote is illustrative of two important elements of liberal democracy. Firstly, within such a system, democracy is the method for ensuring the survival and proper functioning of the liberal state. The goal then is liberalism, not democracy. A liberal state, according to the theories of John Stuart Mill, would be one in which individuals have the utmost freedom to pursue their own interests and ends, with as little state interference as

\footnotetext{
${ }^{1}$ Richard S. Katz, Democracy and Elections (Oxford: Oxford University Press, 1997), 46.
} 
necessary to keep individuals and their property safe. This means, then, that the foremost goal of such a society is to protect the freedom of individuals, while the core ideals of democracy (popular rule, equality, and autonomy) would be secondary. Secondly, Katz's statement recognizes the fact that liberalism developed before democracy. ${ }^{2}$ The prominence of liberal democracy in today's world results from the fact that, in the nineteenth and twentieth centuries, states that adhered to liberal tenets democratized, and thus linked the two concepts together. Additionally, as Katz observes, liberal democracy and capitalism are closely related, since they are usually coupled in practice and share the same fundamental building blocks of an individualistic society and self-centred humans. ${ }^{3}$ The interrelationship between democracy, liberalism, and capitalism, is also present in C. B. Macpherson's explanation of a liberal state. He writes:

The liberal state was a matter of having competing political parties and having certain guaranteed freedoms-freedom of association, of speech and publication, of religion, and freedom of the person, that is, freedom from arbitrary arrest and imprisonment. These freedoms were seen to be both good in themselves and necessary to the working of a competitive party system. The job of the liberal state was, and was seen to be, to provide the conditions for a capitalist market society. The essence both of the liberal state and the market society was competition, competition between individuals who were free to choose what they would do with their own energies and skills, and free to choose whom they would authorize, as governments, to make and enforce the rules which were needed for the competitive market society. ${ }^{4}$

In this sense, liberalism, democracy, and capitalism become mutually reinforcing and their components easily blended.

\footnotetext{
${ }^{2}$ Unless otherwise specified, when discussing liberalism, I am referring to an ideology based on the notion of the primacy of individual freedom, which is achieved via an absence of constraints on each individual.

${ }^{3}$ Katz, Democracy and Elections, 46.

${ }^{4}$ C. B. Macpherson, The Real World of Democracy (Oxford: Oxford University Press, 1966), 46.
} 
Because of the prevalence of democracy in liberal states, many of the features of a liberal state, such as guaranteed individual freedoms and party competition, became integrated into definitions of democracy (rather than just of liberal democracy), making them seem necessary, for some observers, to a democratic state. For example, Beetham purports that there are five characteristics of liberalism, which are "indispensible" to democracy: individual rights (to allow for popular control of the government); an institutional separation of powers (to allow for the "rule of law"); an assembly of representatives, chosen by citizens through an electoral process; a limited state (which implies a restriction of state involvement to the public sphere, leaving, for the most part, civil society, the market, private property, familial life, and personal affairs to citizens); and an acceptance of the premise that the public good is determined by the choice of noncoerced citizens (rather than there being an absolute truth as to what is good for any given society). ${ }^{5}$ Beetham argues that these are crucial elements of state-level democracy because all attempts to carry on without them have proven catastrophic for democracy. ${ }^{6}$ With this logic, however, Beetham commits a social science faux pas-just because a particular occurrence happened a certain way in the past, does not mean that it will happen that way again in the future, since conditions are dynamic in society. Thus, just because these five liberal elements have been necessary to democracy in the past, does not mean that democracy will only be able to function with them.

The philosophy of liberal democracy evolved in the late 1970s and 1980 with the rise of the "New Right," further emphasizing the private good over that of the public. Held explains that according to proponents of the New Right, the modern state acts as a

\footnotetext{
${ }^{5}$ David Beetham, Democracy and Human Rights (Cambridge: Polity Press, 1999), 34-35.

${ }^{6}$ Ibid., 34.
} 
tyrant and hinders individuals' liberty, rather than facilitating the autonomy of individuals, as promised by democracy. The New Right's solution is to 'roll back' the state's jurisdiction to allow for greater individual freedom and more citizen control over affairs. ${ }^{7}$ One of the leading scholars of this movement, Friedrich Hayek, writes that, "liberalism is a doctrine about what the law ought to be, democracy a doctrine about the manner of determining what will be the law." This quote, which shows a likely influence on Katz's conception of liberal democracy, also provides a good example of how the New Right understands the relationship between liberalism and democracy-that democracy is a means to protect liberty, which is the ultimate aim for society, rather than democracy being desirable in and of itself. The philosophy of the New Right developed a strong following in the English-speaking world, ${ }^{9}$ which led to prevalent association between democracy and privatization, cutting back on social spending, and other forms of 'rolling back' or limiting the state. In effect, liberal democracy became more about facilitating capitalism than promoting the humane ideals of equality and freedom.

The defining feature of liberal democracy is its emphasis on the individualindividual freedoms, individual rights, and individual autonomy. Freedom is defined and allocated on an individual basis, where rights are granted to each person to allow them to act according to their will (so long as it does not hurt others), rather than granting group rights or ensuring only a society's collective freedom from tyranny. Beetham more adequately explains this as a difference between liberalism and democracy, which both value human dignity and autonomy, but vary in their meaning of autonomy. Whereas in democratic theory, freedom is a collective good, as it allows all to participate in

\footnotetext{
${ }^{7}$ David Held, Models of Democracy, $3^{\text {rd }}$ Edition (Stanford: Stanford University Press, 2006), 201-202.

${ }^{8}$ Friedrich Hayek, The Constitution of Liberty (London: Routledge \& Kegan Paul, 1960), 103.

${ }^{9}$ Held, Models of Democracy, 207.
} 
establishing policies and laws; in liberal theory, freedom refers to the absence of constraints on individuals. ${ }^{10}$ Some variants of liberalism also do not pay significant recognition to claims made on behalf of communities ${ }^{11}$ because, through this framework of understanding, it is difficult to recognize the ways in which the identity of individuals and their subsequent well-being are shaped through membership in communities. ${ }^{12}$ Thus, the good of the individual will always come before that of the community, even though the two may be intimately linked. Furthermore, individualism fits well with the capitalist system, which is based on competition and an 'every person for him/herself' mentality, and this connects the liberal democratic model to a particular economic system.

Because of the focus on individual autonomy, rights that are introduced and protected within a liberal democracy tend to be individualistic in nature. The argument for the necessity of such rights is as follows: In order for there to be popular control over the government, citizens must be able to decide freely when voting, which means they cannot be coerced into making any particular decision. In order for an individual to practice free choice, each person must be protected from state coercion, which, liberals argue, can only be accomplished through guaranteeing that the state will not infringe on personal freedoms. Furthermore, in order for an election to be competitive and fair (and thus allow for free choice when voting), there must be freedom of speech and assembly, so citizens can discuss options and gather, no matter what political position they

\footnotetext{
${ }^{10}$ Beetham, Democracy and Human Rights, 7.

${ }^{11}$ Other political philosophers, such as Will Kymlicka, do theorize on how to reconcile liberalism and group rights. Kymlicka even purports that protecting group rights is integral to liberalism ("Individual and Community Rights," in Group Rights, ed. Judith Baker (Toronto: University of Toronto Press, 1994), 17 33).

${ }^{12}$ Melissa S. Williams, "Group Inequality and the Public Culture of Justice," in Group Rights, ed. Judith Baker (Toronto: University of Toronto Press, 1994), 34.
} 
represent. ${ }^{13}$ What is interesting about this justification for individual rights is that it seems that liberalism becomes the supporting mechanism for democracy, rather than the reverse, which is likely a hold over in the theory from the early liberal democratic thinkers.

In this justification for the importance of individual rights, elections are introduced as the main mechanism for exercising popular participation in governing. Although elections are the main institution used throughout the democratic world to decide state leadership, an electoral process is not necessarily indicative of liberalism or, for that matter, democracy. As Jean Grugel notes, elections alone cannot indicate whether a country is democratic or democratizing, since many authoritarian regimes may rely on elections to 'prop up' or provide a veil of legitimacy for their government and therefore, Grugel continues, genuine competition between parties or candidates in an election are necessary for it to be considered democratic. ${ }^{14}$ Nevertheless, according to Jack Lively, elections are necessary for popular control of government because they allow citizens to have power over their government in two ways: the government's fear of removal from power, should the population be displeased with its performance, dictates that the government should be responsive to the needs and wants of its citizens and the population can affect the policy course by bringing to power a new government with alternative policies. ${ }^{15}$ Although elections are not ideal mechanisms for determining the wishes of a population, since they can only give an indication of a majority's broad policy stance and because not all issues that will be dealt with by a government come up

\footnotetext{
${ }^{13}$ H.B. Mayo, An Introduction to Democratic Theory ( New York: Oxford University Press, 1960), 64-65. ${ }^{14}$ Jean Grugel, Democratization: A Critical Introduction (New York: Palgrave Macmillan, 2002), 72-73.

${ }^{15}$ Jack Lively, Democracy (Oxford: Basil Blackwell, 1975), 43.
} 
during an election, ${ }^{16}$ elections are the best option available to allow for mass participation in governing (through the selection of leaders and representatives) considering the size of modern states. Furthermore, elections allow for political equality, as epitomized in the mantra of 'one vote, one person,' thus allowing each individual in society equal weight in determining the government. It seems therefore that elections are the best available method for determining a government through democratic means, provided that the elections are meaningful (or, in other words, that the results are not determined by a body other than the citizens of the state whose government is in question).

How to make elections meaningful is a hotly debated topic in democratic literature. Liberals argue that the only way for election results to be valid (the true representation of the population's desires) is through guaranteeing individual rights. For example, Anthony McGann argues that it is senseless to discuss democratic procedures such as elections if citizens cannot make democratic choices, which require the guarantee and realization of 'basic rights.' ${ }^{17}$ Beetham presents a more detailed argument as to why individual rights are necessary to elections and therefore democracy. He maintains that the rights to free expression, freedom of association, and so on are meant to bolster the public activity of persuading others to a particular point of view or rallying people together in hopes of convincing the government to address a particular concern of the public. ${ }^{18}$ Thus, such rights are not meant for the individual in isolation from others, but rather as a way to foster associational life in a country. The question remains, however, if the formula of "elections plus individual freedoms equals democracy" is the only one

\footnotetext{
${ }^{16}$ Mayo, An Introduction to Democratic Theory, 87-88.

${ }^{17}$ Anthony McGann, The Logic of Democracy: Reconciling Equality, Deliberation, and Minority Protection (Ann Arbor: The University of Michigan Press, 2006), 7.

${ }^{18}$ Beetham, Democracy and Human Rights, 17.
} 
that allows democracy to be meaningful in society and, in particular, if such a formula would suit societies and cultures that do not have a liberal tradition to support the notion of the supremacy of the individual.

This leads us to one of the major problems with defining democracy in a way that implies liberal democracy: that it makes democracy exclusive to liberal countries. Before explaining this, I must address one potential issue with this statement: If both democracy and liberalism are western concepts, why I am suggesting that one is transplantable to all countries, while the other is not. Democracy, if understood as a set of normative underpinnings, could be adopted by any society and interpreted to suit cultural preferences. Democracy's adaptability is not a new proposition in academia. Beetham, who believes that, when assessing if a country is democratic, the underlying principles of democracy are more relevant than the institutions present, notes that there is a wide range of potential forms of social organization and political structures that could be both democratic and allow for the expression of different cultural practices, national traditions, and distinct historical developments. ${ }^{19}$ Furthermore, Samuel Huntington purports that every culture has elements within it that are consistent with democratic principles, just as western society and, in particular, the major religions of Europe that played a significant role in the development of European society, have non-democratic characteristics. $^{20}$ Liberalism, on the other hand, is an ideology, which is used to frame how individuals view society and as such, contributes to a particular manifestation of

\footnotetext{
${ }^{19}$ Beetham, Democracy and Human Rights, 4 \& 17.

${ }^{20}$ Samuel P. Huntington, "Democracy's Third Wave," in The Global Resurgence of Democracy, ed. Larry Diamond and Marc F. Plattner (Baltimore: John Hopkins University Press, 1996), 21.
} 
democracy. ${ }^{21}$ Liberalism developed into the West's ideological preference gradually: Beginning with Hobbes and his emphasis on the individual in political life, liberal notions steadily spread and grew in popularity to the point that they have become the accepted norm. However, in other parts of the world, liberalism did not slowly embed itself into the cultural fabric. Rather, other forces were at work. For example, in East Asia, Huntington notes the effect of Confucianism on these societies, which led them “...[emphasize] the group over the individual, authority over liberty, and responsibilities over rights. ${ }^{, 22}$ In Russia, there is also an impetus to put the community ahead of the individual, dating back to Tsarist times and the introduction of the doctrine of sobornost'. Although this term was originally used within the Russian Orthodox Church, its meaning_-"the spirit of communality"—applied to peasant life and the way in which people lived and related to each other. ${ }^{23}$ As a result of these different belief systems, other philosophical traditions developed and came to dominate the cultural mentality of these nations, thus making liberalism and its emphasis on the individual seem foreign and unnatural. Subsequently, if a definition of democracy were to be based solely on liberal elements, it would be difficult for non-western countries to implement successfully the necessary institutions to create a functioning state.

The conjecture that liberalism (and, as a consequence, liberal democracy) emerged slowly through unique a unique historical process is not new to democratic studies. In Social Origins of Dictatorship and Democracy, Barrington Moore presents

\footnotetext{
${ }^{21}$ I use the term "ideology" in the Marxist sense, whereby "... ideology is the system of the ideas and representation which dominate the mind of a man or a social group." (Louis Althusser, "Ideology and Ideological State Apparatuses," in "Lenin and Philosophy" and Other Essays (1970).

[http://www.marxists.org/reference/archieve/althusser/1970/ideology.htm]).

${ }^{22}$ Huntington, "Democracy's Third Wave," 15.

${ }^{23}$ Marina Bykova, "Nation and Nationalism. Russia in Search of its National Identity," in Civil Society, Religion, and the Nation. Modernization in Intercultural Context: Russia, Japan, Turkey, eds. Gerrit Steunebrink and Evert van der Zweerde (Amsterdam: Rodopi, 2004), 33.
} 
his theory of the development of democracy in the West. He writes that there were five conditions that led to the development of democracy: the establishment of a balance of power and authority between the monarchy and aristocracy; the development of commercial agriculture; a weakening of the aristocracy's power in favour of the town dwellers or bourgeoisie; the prevention of an alliance against the peasants and/or workers on the part of the noble and merchant classes; and a revolutionary break with the past that dismantles the remaining power structures that hindered democratic practices. ${ }^{24}$ In addition to tracing the development of democracy, these five steps also show the development of liberalism and capitalism, particularly in noting the emergence and ascension to power of the merchant class. Moore's structural approach to understanding democratization not only demonstrates how liberalism, democracy, and capitalism came to be so closely related, but also suggests that the form of democracy we have in the West is the result of a special set of historical processes that cannot be easily replicated in other areas. Macpherson outlines these stages in broader terms, writing, “...before democracy came into the western world there came the society and the politics of choice, the society and politics of competition, the society and politics of the market. This was the liberal society and state." 25 Thus, although democracy resulted from a set of historical processes, only liberalism is uniquely western, as there are other legitimate and nonwestern forms of democracy. ${ }^{26}$ Macpherson argues that it is improper to equate democracy with 'our unique western liberal-democracy,' as there are non-liberal systems

\footnotetext{
${ }^{24}$ Barrington Moore, Social Origins of Dictatorship and Democracy: Lord and Peasant in the Making of the Modern World (Boston: Beacon Press, 1966), 426-427.

${ }^{25}$ Macpherson, The Real World of Democracy, 6.

${ }^{26}$ For example, some Iroquois tribes practiced a form of participatory democracy.
} 
that exist and are legitimate successors to the ancient concept of democracy. ${ }^{27}$ These systems, as well as other models of non-liberal democracy, will be explored later in this chapter.

When we define democracy in such a way that it is limited to the ideology of liberalism, in effect, we are limiting democracy to liberal countries. In some cases, this could be the intended result, as democratic rhetoric can be used as a political tool by the West to chastise other governments, particularly when their interests do not converge. However, if the West is honest in its claim that democracy should be a worldwide system and in its actions of democracy promotion, then thinking of democracy only in liberal terms artificially limits it and may set democratizing states up for failure. In addition, we cannot base our definition of democracy on institutions and procedures of the West because it would not equip us to accurately discern between which non-western institutions and practices are democratic in nature and which are in no way beneficial to democracy. ${ }^{28}$ To be clear, the aspects of liberalism that I find particularly problematic when applied to a definition of democracy are the supremacy of the individual and the notion that the state should play a minimal role in society because it encroaches on the freedom of individuals. Thus, when I criticize the idea of liberal democracy as the only viable form of democracy, I am primarily taking issue with these two aspects being attached to the meaning of democracy.

Furthermore, the term liberal democracy itself introduces an epistemological concern that plays out in much of the literature on democracy. The issue begins with conceptual stretching. Giovanni Sartori observes that while social scientists have

\footnotetext{
${ }^{27}$ Macpherson, The Real World of Democracy, 3.

${ }^{28}$ Beetham, Democracy and Human Rights, 153.
} 
extended their focus beyond western states to worldwide projects, the vocabulary available to describe non-western experiences remains limited to western terminology. In order to deal with the subsequent problem of having concepts which are too specifically western to describe and classify accurately non-western experiences, conceptual stretching-the broadening of the meaning and therefore the applicability of current concepts—-was adopted in academia. ${ }^{29}$ As a result, concepts have become unclear and without distinct boundaries, and thus have become a type of universal category that is irrelevant to defining and understanding our world from a social science perspective. ${ }^{30}$ Certainly, the term democracy has fallen victim to conceptual stretching, as it is the political system $d u$ jour that nearly every state seeks to identify with for a source of political legitimacy in the eyes of the international community. Fareed Zakaria remarks:

Democratically elected regimes, often ones that have been reelected or reaffirmed through referenda, are routinely ignoring constitutional limits on their power and depriving their citizens of basic rights and freedoms. From Peru to the Palestinian Authority, from Sierra Leone to Slovakia, from Pakistan to the Philippines, we see the rise of a disturbing phenomenon in international life-illiberal democracy. ${ }^{31}$

Although also an example of the 'counter attack' to conceptual stretching, Zakaria's statement illustrates how the stretching of democracy allows a wide range of regimes to claim that they are part of this category, when other observers would suggest that many of these regimes are clearly not democratic. The stretching of democracy in this case is to reduce its qualifying criteria to a democratic election, thus making democracy useless in distinguishing between governments. As an extreme example, Nazi Germany would

\footnotetext{
${ }^{29}$ Giovanni Sartori, "Concept Misformation in Comparative Politics," The American Political Science Review 64, no. 4 (1970): 1034.

${ }^{30}$ Ibid., 1035.

${ }^{31}$ Fareed Zakaria, "The Rise of Illiberal Democracy," Foreign Affairs 76, no. 6 (1997): 22.
} 
then be considered a democracy, as Hitler came to power through an election. Stretched, democracy has no specific meaning and, as Robert Dahl comments, "a term that means anything means nothing., 32

In response to a broadened understanding of democracy, political scientists began adding adjectives before the noun to create more useful and precise terms, thus breaking democracy into a series of sub-categories; illiberal democracy being one example. Grugel argues on behalf of this tactic because adjectival democracy helps us distinguish between regimes that have democratic features, but do not fit the western mould of democracy. ${ }^{33}$ Perhaps this would hold true if there were a set of agreed upon subcategories; however, the number of adjectives preceding democracy continues to increase with each new scholarly take on classifying non-liberal regimes. For example, in "Managed Pluralism: Vladimir Putin's Emerging Regime," Harley Balzer notes the proliferation of adjectives, writing, "Political regimes where leaders are selected in elections that are reasonably free but hardly fair have been variously described as electoral, virtual, illiberal, pseudo, managed, delegative, ruled, partial, guided or incomplete democracies; or as electoral, competitive or hybrid authoritarian regimes." ${ }^{34}$ Even the Putin administration caught onto this trend, introducing the concept of sovereign democracy (discussed in chapter one), to the parlance, thus further obfuscating the term democracy. If we continue in this line of thought, liberal democracy becomes another form of adjectival democracy; however, it carries with it an implicit assumption of superiority as a model from which all other forms of democracy deviate. Returning to

${ }^{32}$ Robert A. Dahl, Democracy and its Critics (New Delhi: Orient Longman Limited, 1991), 2.

${ }^{33}$ Grugel, Democratization, 5.

${ }^{34}$ Harley Balzer, "Managed Pluralism: Vladimir Putin's Emerging Regime," Post-Soviet Affairs 19, no. 3 (2003): 190. 
the quotation from Zakaria's article, it is obvious through his choice of adjective that he values liberal democracy highly and sees it as the most desirable form of democracy. Since there has been a proliferation of adjectives in democratic literature, this form of categorization also becomes useless, since (theoretically) there could be a different adjective for every country's version of democracy, thus making such terms useless for comparison. What is needed then, is a definition of democracy that is both precise enough to prevent conceptual stretching, but also broad enough not to have a cultural bias that would prevent any variations of democracies to be excluded. According to Sartori, such a definition would fit into the medium level of abstraction, where the concept is neither universal nor too specific, but rather emphasises the similarities between cases. ${ }^{35}$ Alternative Models of Democracy

As previously mentioned, a number of models of democracy have been suggested, which do not fit within a liberal framework. Grugel purports that rather than defining democracy through the 'trappings of liberalism,' a procedural approach is more appropriate, such as that put forth by Beetham, who describes democracy as a method of decision-making controlled by a set of people who decide on collectively binding rules and policies. ${ }^{36}$ Although such a definition does lack liberal overtones, it is also not particularly precise, consisting only of the criterion of popular rule and mentioning nothing of equality or freedom, both of which have been historically associated with democracy.

Another much-touted alternative to liberal democracy is the "East Asian Model." Huntington explores this version of democracy while discussing whether culture is an

\footnotetext{
${ }^{35}$ Sartori, "Concept Misformation in Comparative Politics," 1041.

${ }^{36}$ Grugel, Democratization, 6.
} 
obstacle to democratization. He notes that in Japan, at the time of writing, the ruling party had never been voted out of power, yet despite the absence of fluctuation in who holds power, Japan is still 'unquestionably a democracy' since there are free and fair elections. ${ }^{37}$ Huntington suggests that the dominant-party systems present in East Asia (including South Korea, Taiwan, Malaysia, and Singapore, in addition to Japan) represent, "an adaptation of Western democratic practices to serve not Western values of competition and change, but Asian values of consensus and stability." ${ }^{38}$ Although the East Asian Model does not consist of a definition of democracy in itself, it suggests that democracy is adaptable to different cultures and, in particular, non-liberal values. This is supported by the case of India, where a distinct form of democracy developed, which was influenced by the country's history and cultural traditions. ${ }^{39}$ However, looking specifically at what Huntington used to determine that Japan is democratic-electionsreveals that he adheres to a minimalist or procedural approach. In effect, Huntington and Beetham have engaged in conceptual stretching, since they broadened the scope of what systems constitute democracy by reducing the properties (or determining criteria) for the term democracy.

In The Real World of Democracy, C. B. Macpherson presents three different variants of democracy: liberal, communist, and underdeveloped. According to Macpherson, what classifies each of these forms as democratic is their "ultimate ethical principle.' He writes:

${ }^{37}$ Huntington, "Democracy's Third Wave," 17.

${ }^{38}$ Ibid., 18.

${ }^{39}$ Shmuel N. Eisenstadt, "The Resurgence of Religious Movements in the Processes of Globalization Beyond the End of History or the Clash of Civilizations," in Democracy and Human Rights in Multicultural Societies, ed. Matthias Koenig and Paul de Guchteneire (Paris: UNESCO, 2007), 246. 
In each case the aim is to provide the conditions for the free development of human capabilities, and to do this equally for all members of the society. In each case the essence of man is taken to be activity in pursuit of a rational conscious purpose. And in each case the realization of this essence is seen to require both freedom and equality: freedom of each individual from subservience to the wills of others, and equality in this freedom. ${ }^{40}$

Once again, we see presence of freedom and equality in connection to democracy, though this particular quote does not link popular rule to democracy. Nevertheless, in each of the variants, an element of popular rule is present.

Since the first section of this chapter focussed on liberal democracy, I will only provide an explanation of the communist and underdeveloped models of democracy. Although the dissolution of the Soviet Union and recognition of the fallacies within communist states have discredited the communist variant of democracy in the minds of most people, it is still a legitimate version of democracy, if only in theory. The original call of Marx's Communist Manifesto was for the oppressed class of society, the proletariat, to rise up and claim power for themselves, thus ushering in a classless society. By doing so, a democratic utopia would emerge, as all individuals would be equal, participate in their own governing, and would be free from the domination of others. ${ }^{41}$ This communist democracy would differ from a capitalist one in that it would include economic democracy, not just political, meaning that everyone would own production as well as work to produce, thus eliminating economic power relations. Such a variant of democracy would include popular rule since complete equality between individuals in a realized communist democracy would mean that no one individual or group would have

\footnotetext{
${ }^{40}$ Macpherson, The Real World of Democracy, 58-59.

${ }^{41}$ Ibid., 22.
} 
power over others, and thus, all would participate in the ruling of society as equal members.

However, Macpherson is not nearly this idealistic in explaining the communist variant of democracy. Rather, he equates it with a one party state, based on the models of the Soviet Union and China. Although acknowledging that communist states do not have a legitimate claim to the narrow sense of democracy (as a system to choose and authorize governments), he grants that they could be democratic in a broader sense of achieving human equality if they have as their purpose the achievement of a classless (and therefore democratic) society. ${ }^{42}$ In order for a one party state to be democratic in the narrow sense, it must have full intra-party democracy, open membership, and reasonable requirements for participation. ${ }^{43}$

Macpherson's underdeveloped variant of democracy comes from his observations of political developments in Africa and Asia after decolonization and is based Rousseau's notion of the general will. He suggests that the demands placed on the governments of these newly independent countries (to modernize, raise productivity, maintain independence, and improve the lives of citizens) require strong political leadership, which comes most naturally from the major political party that came to power during the struggle for independence. ${ }^{44}$ At this time, the dominant party demonstrated that it was able to capitalize on the general will of the population (which dictated a propensity for independence) and maintain it until the goal was achieved. Macpherson speculates that if desire for the aforementioned demands held by a majority of people, then they are likely to back the leader and party that helped create their new state rather than finding a

\footnotetext{
${ }^{42}$ Macpherson, The Real World of Democracy, 22.

${ }^{43}$ Ibid., 21.

${ }^{44}$ Ibid., 26.
} 
competitive party structure useful in achieving their ends. ${ }^{45}$ He also purports that such a system would be democratic so long as there is a general desire to accomplish such largescale projects and that this will is stronger than any other wills in society and is kept strong by an increasing number of people participating in public life. ${ }^{46}$ Furthermore, the desire for modernization, etc. is fuelled by a desire for equality and freedom (in particular, to be on par with the western world), which is the goal of democracy.

The underdeveloped variant of democracy has two major areas that make it vulnerable to criticism. On the one hand, the terminology of underdevelopment implies a western bias and assumption that the systems included in this form of democracy are less desirable than those that are fully developed (i.e. the West). According to Howard Handelman, the label of "underdeveloped" denotes inferiority and "backward" political and economic systems and consequently, lost favour amongst scholars. ${ }^{47}$ Furthermore, this terminology is linked to modernization theory, which suggests that Third World countries should follow the path of the West to develop. ${ }^{48}$ Once again, by putting forth the West as the exemplar to emulate, there is an assumption that those needing to follow the West are substandard. Modernization theory is also now seen to be a flawed model for understanding development, since it ignores international factors that may affect the developing country, unjustifiably dismisses traditional values in favour of modern culture, and does not account for the occurrence of political instability that may accompany economic modernization. ${ }^{49}$ Despite the terminological difficulties with this

\footnotetext{
${ }^{45}$ Macpherson, The Real World of Democracy, 26.

${ }^{46}$ Ibid., 29.

${ }^{47}$ Howard Handelman, The Challenge of Third World Development, Fourth Edition (Upper Saddle River, N.J.: Pearson Prentice Hall, 2006), 1.

${ }^{48}$ This is not surprising, given that Macpherson wrote The Real World of Democracy in 1966, when modernization theory was at the height of its popularity.

${ }^{49}$ Handelman, The Challenge of Third World Development, 14.
} 
model, the basic idea presented by Macpherson is an interesting model of democracy to consider. The three major elements of democracy-popular rule, political equality, and freedom - are present, while at the same time lacking the basic structure of liberalism.

Nevertheless, the other potential weakness of this model is its reliance on the idea of the general will, a notion that has been heavily criticized. Joseph Schumpeter argues that the general will is a social construct, lacking a rational basis and easily shaped by governments or the media. ${ }^{50}$ Furthermore, Schumpeter contends that the public is insufficiently informed and involved in democratic processes for there to be any sort consensus that would lead to a defined general will. ${ }^{51}$ Charles Taylor suggests that relying on a general will for political decision-making is a threat to freedom because Rousseau's conception of the term relies on the ethic of virtue, which is lacking, if not untenable, in modernity. Without virtue, the notion of a general will could be used to justify or prop-up any type of political structure, regardless of whether it is actually democratic. ${ }^{52}$ H.B. Mayo criticizes the language of "general will" as too vague to be useful. $^{53}$ Not only does he contend that it is unclear who determines it, but also that it is difficult to ascertain what that will would be, particularly for policy issues.

It is important to clarify what I mean by the general will before justifying the use of this concept. I am no longer using the general will in the Rousseauan sense, where it exists within all members of society. Instead, I now take the general will to be the majority's opinion on a general issue. This understanding is actually somewhat similar to Rousseau's concept of the "will of all." As such, the idea of a general will should not be

\footnotetext{
${ }^{50}$ Held, Models of Democracy, 148.

${ }^{51}$ McGann, The Logic of Democracy, 27.

${ }^{52}$ Charles Taylor, "Invoking Civil Society," Working Papers and Proceedings of the Center for Psychosocial Studies, no. 31 (Chicago: Center for Psychosocial Studies, 1990), 14.

${ }^{53}$ Mayo, An Introduction to Democratic Theory, 89.
} 
so easily dismissed. Firstly, the general will is not a mechanism to determine precise policy issues. Rather, as Macpherson suggests, the general will can only indicate support for major initiatives for a state to undertake or popular desires, like modernization, improving the general welfare of citizens, democratization, or having particular state leadership. By defining the general will as an indication of the desired direction for a society, rather than of decisions on specific political issues, it should address part of Mayo's concerns as well as Schumpeter's second critique, since a high degree of participation and specialized political knowledge are not necessary.

In response to the contention that a state's claim to be following the general will could be a guise for dictatorships, I purport that the classification of the governmental system should not matter, as long as it is an expression of what the people want. In this way, the style of rule is irrelevant if the people actually desire to be ruled as such. However, one must be careful with this argument. As J.L. Talmon argues, the general will, understood as Rousseau presents the concept, can be used to support a totalitarian regime. If it is accepted that there is a general will in society, those who purport to know and embody it and, as such, are given power, are then left free to control the nation without verifying that their actions are representative of the actual general will. ${ }^{54}$ Those in power, then, are able to coerce citizens into supporting the government's actions and policies, since, according to the nature of Rousseau's general will, those who think they do not agree with the general will just do not realize that they actually do agree with it, or in this case, what the rulers say it is. Talmon is correct in his assessment that this is a dangerous use of the general will and an abuse of democratic ideals. However, in the way that I use the general will as a basis for democracy, such a situation should not arise

${ }^{54}$ J.L. Talmon, The Origins of Totalitarian Democracy (London: Secker \& Warburg, 1952), 48. 
because the population must be consulted on a regular basis and should not be coerced into supporting a particular viewpoint. Since I link the general will to majority opinion rather than an innate idea within each individual, this stipulation should prevent a group or individual from claiming to know the general will and assuming power based on this claim. In this way, a more authoritarian style of governing that claims to be democratic is reflective of Macpherson's underdeveloped variant of democracy. Based on the idea of popular control of government, such systems could be democratic if the people's will is actually carried out and all citizens are able to participate in political life freely and on an equal basis. Of course, an absence of liberal democratic institutions and a claim of following the general will brings up the problem of how to determine the will and Schumpeter's caution of media manipulation.

Elections, though not useful in determining the general will on specific issues, do provide broad policy directives ${ }^{55}$ and, depending on the strength of the majority supporting the elected leader or party, could also provide indication of the general will in terms of desired leadership. Of course, this is dependent on the elections being run fairly with open suffrage. Furthermore, in order for elections to be used as a means of determining the popular will (and, in general, as an instrument of democracy), there must be an option for the voters to choose between. This means there must be more than one candidate or party running, which would ensure the government could be changed and that a single party system could not claim itself to be a democracy based on popular support demonstrated through elections. Another mechanism for determining the general will is by employing public opinion surveys, which can provide signals as to the mood and desires of the public. Opinion polls can reveal support ratings for the state's

\footnotetext{
${ }^{55}$ Mayo, An Introduction to Democratic Theory, 88.
} 
leadership, which is a major indication of whether the governors are meeting and sustaining the general will. However, both of these options for identifying the general will are susceptible to manipulation by the incumbent government: But is this influence enough to change the general will?

The argument that the general will can be controlled by the government was put forth by Jürgen Habermas in The Structural Transformation of the Public Sphere: An Inquiry into a Category of Bourgeois Society (1989). He argues that there has been a "refeudalization" of the public sphere in which authority and prestige are granted to public authorities on the basis of their position and politics is turned into a managed performance, where the majority of citizens are excluded from public decision-making and are instead treated as a controlled resource from which political leaders can obtain, with the aid of media techniques, sufficient consent to legitimize their rule. John Thompson criticizes this position, as it assumes too much concerning the process of media reception and presupposes that the recipients of media passively intake what they are presented with and are easily swayed by spectacle. ${ }^{56}$ Thompson contends that context and personal interpretation affect how media products are received and integrated into the lives of individuals. ${ }^{57}$ Although Thompson acknowledges that the media can influence people's opinions, the extent of the role that media can play is only to guide, but not control, the opinions and actions of recipients of a particular message. Because the producers of messages do not receive direct feedback from the recipients, the message cannot be "tweaked" for each individual to generate the producer's desired response. Since mass media messages reach a broad and diverse group of people, each of whom

${ }^{56}$ John B. Thompson, The Media and Modernity: A Social Theory of the Media (Stanford: Stanford University Press, 1995), 74.

${ }^{57}$ Ibid., 75. 
possesses a unique combination of abilities, experiences, and expectations, it would be impossible for media producers to elicit the same response in each recipient based on one message. ${ }^{58}$ Thus, although governments may try to control public opinion through media manipulation, and therefore the general will, they will not fully realize their objective, but can only hope to influence the opinions of some of the population.

Overall, the general will, as determined through fair and competitive elections and public opinion surveys and regarding overarching state objectives or trajectories, provides a legitimate basis for democracy, so long as the state is responsive to its citizens. Put in more simplistic terms, a crucial indicator of whether a country could be considered democratic is whether there is popular support for the overall direction in which the country is moving, its institutions, and its government. In the event that there is widespread support for these things, it seems incorrect to suggest that the country is not democratic, considering that the main wishes of its citizens are being followed. If we conceive of the popular control of government as the execution of the general will, then we have overcome the need to define democracy with liberal elements in order for it to be a precise and useful term. As long as the other core elements of democracy are also present-equality and freedom—a state that administers the general will of its citizens should be considered democratic.

In order for there to be equality, however, there is a requirement that has yet to be explored in this thesis - the protection of minorities. This is especially vital when basing democracy on my conception of the general will, since, theoretically, the majority could decide to trample the rights of, or, in an extreme case, exterminate, a minority group. Michael Ignatieff writes that so long as disadvantaged groups in society are guaranteed

\footnotetext{
${ }^{58}$ Thompson, The Media and Modernity, 114.
} 
rights to ensure their survival, members of these groups will be able to provide from themselves and participate in society on an equal basis with others. ${ }^{59}$ Leslie Green notes that some minority groups that belong to particular ethnic, cultural, or religious communities have specific collective interests tied to their identity and the existence of their groups. ${ }^{60}$ As long as these individuals are protected from a majority decision that would hurt them or their group's survival and that members of these groups are able to participate fully in civic life and therefore in the determination of the general will, then democratic standards should be met. Such protection can be achieved through legislation and the judiciary's enforcement.

When applied to Russia, this definition of democracy challenges the assumptions of many observers regarding democracy and democratization under Putin. As pointed out by a number of Russian scholars in chapter one, liberalism seems ill-suited to Russia, so it is not surprising that the political situation under Putin and Russia's institutions do not match those of the West. However, considering the popular support for Putin during his two terms as president, it is possible that Russia could be considered a democracy or, at the very least, democratizing, according to the definition of democracy put forth in this thesis project. ${ }^{61}$ Supporting this hypothesis is the model of underdeveloped democracy. Although Russia does not match the post-colonial foundation of this theory, there are a number of similarities between post-colonial and post-Soviet struggles, namely the need to rebuild the state, firmly establish independence and a place in international affairs, and

\footnotetext{
${ }^{59}$ Michael Ignatieff, The Rights Revolution (Toronto: House of Anansi Press, Inc., 2000), 118.

${ }^{60}$ Leslie Green, "Internal Minorities and Their Rights," in Group Rights, ed. Judith Baker (Toronto: University of Toronto Press, 1994), 104.

${ }^{61}$ Since Putin has had consistently high support ratings, which generally hovered around 70 percent approval, and was elected and re-elected into the post of president with a large majorities, his presidency could be understood in terms of it being the execution of the general will of Russians.
} 
create the conditions for social peace. The next few chapters will focus specifically on Russia from 2000 to 2008 , and test the hypothesis that Russia is democratic, as it is the desire of the majority of the population to have a democracy with a strong leader. 


\section{Chapter 4: Examining the Putin Years}

In the previous chapters, I attempted to identify the essence of democracy in order to overcome the assumption that liberal democracy is the only meaningful understanding of democracy. My argument is that as long as a state demonstrates the three major elements of democracy, no matter the institutional arrangements or substantive choices of the government, this system could legitimately be considered democratic. As such, no adjectives would be necessary to clarify the degree or type of democracy. Furthermore, this conception of democracy should be suitable to any range of political, historical, or cultural traditions, since unlike liberal democracy, which necessarily includes liberal institutions, an understanding of democracy as a set of normative underpinnings does not include elements that may not be appropriate for every nation. A review of democratic theory revealed three major elements of democracy that are critical to the essence of democracy: popular control of the government, equality, and freedom. Although the institutional forms of these three criteria may vary in different manifestations of democracy, inclusion of them are integral to democracy. In this respect, all the variants of democracy denoted by various adjectives could be considered as sub-categories of democracy or as variations to suit various political cultures, if, of course, the forms are truly democratic. Although there could be any number of such variations, the two emphasized in this paper are the liberal and general will variants. For ease when referring to the latter, I will label this variant as consensus democracy.

Consensus democracy is appropriate for countries that emphasize community and agreement (as opposed to the individual) and support a strong state (rather than a restricted government). If the government follows the general will of its citizens, that is, 
the majority's opinion in regards to general state issues or objectives, then the criterion of popular control over the government is met. If citizens under such a system are all able to participate equally in determining the general will and have the freedom to make meaningful choices in their lives, even if they end up in a minority on an issue (or many issues), then, regardless of whether such a system appears so to western standards, this system should be considered democratic.

However, when using consensus democracy to determine if a country is democratic, it is important to look at not only how well the aforementioned conditions are met, but also factors that could be counterproductive to popular control, equality, and freedom because this allows for a more accurate picture of the country's level of democracy. A number of hazards to democracy are particularly pressing when considering consensus democracy, all of which stem from hindering the popular control of government. Firstly, if the people belonging to the polity do not want to live in a democracy, then the state could not be democratic, since the system of governance would not be according to the will of the people. Considering that democracy is generally viewed as the best system under which to live in our world today, perhaps a more imminent threat to popular rule would be if the government acts contrary to the general will or the core elements of democracy. Accordingly, the government must consider itself democratic and therefore ensure that citizens have equality within the political process, minorities are protected, citizens are offered meaningful choices, and the results of general will polling including elections are not manipulated. The effect of this would be that each citizen (rather than the government) would be able to control his/her own life. Another issue that could counteract democracy is an absence of democratic rules 
and procedures. In order for a democracy to work, all the political actors must agree to follow a set of rules and there must be a method of recourse for any disaffected parties to resolve their differences. Essentially, this is what Juan J. Linz and Alfred Stepan suggest occurs in a consolidated democracy: political, economic, and social actors do not attempt to realize their goals through non-democratic means; the majority of the population believes that democracy is the best system by which to govern society; and both the government and non-governmental entities are subject to and resolve conflicts through laws and democratic procedures. ${ }^{1}$

With these possibilities of undemocratic behaviours in mind, this chapter will set out to test whether Russia under President Putin could be considered democratic, based on the idea of consensus democracy. To do so, there will be three major parts in this chapter. First, there will be a brief discussion of Russian political culture to demonstrate that the consensus variant of democracy is most appropriate for the case of Russia. The second section will look at public opinion data, to examine whether the general trajectory of the Russian state matches what the majority of Russians desire. This section will look at whether Russians want a democratic system and how they view their country and its institutions and government under Putin. Due to the time and financial restraints of this project, conducting original public opinion research was not possible; however, in order to provide a balanced statistical picture, I have used data gathered by both Russian (state and independent) firms, as well as by western scholars.

The third section will focus on national elections in Russia between 2000 and 2008. Although it would be necessary to study all of the country's political institutions in

\footnotetext{
${ }^{1}$ Juan J. Linz and Alfred Stepan, Problems of Democratic Consolidation and Transition: Southern Europe, South America, and Post-Communist Europe (Baltimore: John Hopkins University Press, 1996), 6.
} 
order to assess fully whether Russia is democratic, the scope of this project does not allow such an ambitious undertaking. As such, I decided to focus specifically on elections for several reasons. Firstly, it is one of the key institutions of a democracy and of determining the general will and therefore must operate according to a formal set of rules and procedures. Secondly, in order to look at elections, other elements of democracy must be examined, particularly those of political equality and freedom in decision-making. Checking if the rules are followed and that citizens have freedom and equality during election periods also provides an opportunity to verify whether minorities (both ethnic and political) are protected. Finally, studying elections provides an opportunity to judge whether the election results are a reflection of government coercion or the general will, a crucial indicator of whether Putin's Russia could be considered democratic.

$\underline{\text { Russian Political Culture }}$

Political culture, as defined by the Oxford Concise Dictionary of Politics, consists of "The attitudes, beliefs, and values which underpin the operation of a particular political system." In their pioneering study of political culture, Gabriel Almond and Sidney Verba define the political culture of a nation as, "...the particular distribution of patterns of orientation toward political objects among the members of the nation."3 In particular, their understanding of political culture refers to the attitudes of citizens toward their state's political and institutional arrangements and their perceived roles within such arrangements. ${ }^{4}$ Although the dictionary entry goes on to caution using political culture as

\footnotetext{
2 "Political Culture," Oxford Concise Dictionary of Politics (Oxford: Oxford University Press, 1996), 379.

${ }^{3}$ Gabriel A. Almond and Sidney Verba, The Civic Culture: Political Attitudes and Democracy in Five Nations (Boston: Little, Brown and Company, 1965), 13.

${ }^{4}$ Ibid., 12.
} 
a variable in analysis, since it could be used to explain anything and therefore describes very little, political culture should not be dismissed so easily.

Almond and Verba comment that studying political culture is a worthwhile exercise since they believe that 'specific learning of orientations to politics and of experience with the political system,' has been largely overlooked in political science and can provide valuable information of citizens' 'political feelings, expectations, and evaluations' resulting from personal experiences that influence the political life of a country. ${ }^{5}$ Furthermore, humans do not all think alike, nor do they hold the same values and this, at least in some part, can be explained by how they were raised and the principles and standards they were taught or, in other words, by their interactions with other around them and their own life experiences. This is why political culture is useful in understanding how democracy functions (or fails to function) in various states: The historic and cultural preferences of citizens form precedents, which can be helpful in understanding current preferences. Although Almond and Verba suggest that each type of political system (traditional, authoritarian, or democratic) has a distinct political culture and that a "civic" culture is necessary for a functioning democracy, I disagree that there is one democratic political culture. Rather, each country's distinct political culture can accommodate the three core elements of democracy, but with the result of a wide range of institutional, procedural, and normative differences between manifestations of democracy.

In chapter one, I highlighted a theme of Russia as its own civilization, which came up several times in the Russian literature. The basis of this idea provides some insight into Russia's political culture. In "About Russia as a northern civilization,"

\footnotetext{
${ }^{5}$ Almond and Verba, The Civic Culture, 33.
} 
Sergei Samuilov describes Russia's historical development as it pertains to modern trends in Russia society. ${ }^{6}$ He explains that since the formation of Kievan Rus' in the ninth century, the lands that now make up Russia have always been impoverished, because of both its climate and geopolitical situation. ${ }^{7}$ This poverty made it difficult for Russians to survive individually (particularly in terms of agriculture production), so they came to count on 'their community, a strong landlord, or the state' to survive. ${ }^{8}$ This practice was further institutionalized in the state of Muscovy (during the fourteenth to sixteenth centuries) with the creation of a political model that resembled a patriarchal family, whereby the head of the family (the landlord) ruled over not only the lands, but also the people living there. This system of rule (which continued under the tsars and communists) forced the majority of the population to submit to the control of the ruler, thereby stunting the development of individualism and entrepreneurialism and encouraging dependency on those who hold power. ${ }^{9}$ In short, Samuilov argues that specificities of the development of the Russian state forced Russians to become community-oriented and reliant on their rulers.

In a quest to understand the periods of social breakdown in Russia, Tim McDaniel argues that there is a distinct "Russian Idea," which when united with modernization and state power, causes deep rifts in society. Although the main thrust of his argument is not overly pertinent to this thesis project, his understanding of the Russian idea is, since it echoes Samuilov's assessment of Russian political culture. According to McDaniel, the

\footnotetext{
${ }^{6}$ At the end of this article, Samuilov posits that Russia needs to find its own, original economic and democratic arrangements to suit its unique culture as a northern civilization. Although he goes into detail regarding a possible economic model, as with the other Russian articles discussed in chapter one, he does not explain what kind of democratic structure would best suit Russia.

${ }^{7}$ Sergei Samuilov, "O Rossii kak o severnoi tsivilizatsii," Svobodnaia mysl' 5, no. 1576 (2007): 22.

${ }^{8}$ Ibid., 25.

${ }^{9}$ Ibid., 29-30.
} 
Russian idea, which exists in both intellectual and lay understandings of society is “...the conviction that Russia has its own independent, self-sufficient, and eminently worthy cultural and historical tradition that both sets it apart from the West and guarantees its future flourishing." ${ }^{10}$ He notes that this term encompasses the following aspects: a repudiation of individualism and utilitarianism, a strong sense of community, distrust toward private property, a preference for informal social relations, and a proclivity toward a strong and paternalistic state. ${ }^{11}$ Like Samuilov, McDaniel also links the genesis of a distinct Russian culture to peasant life, which necessitated a strong sense of community and reliance on others, rather than just oneself. ${ }^{12}$

Putin used the idea of a unique conception of Russian political culture to appeal to voters. Shortly before taking over the presidency from Yeltsin, he published a document that outlines his vision for Russia. In addition to emphasizing the need for a strong state and an efficient economy, Putin refers to the necessity of governing in accordance with Russia's history and traditions_- what he also terms the Russian idea (rossiiskaia ideia). According to Putin, the four major parts of this idea are patriotism, taking pride in one's country; statehood (derzhavnost'), which implies a great and sovereign country; statism (gosudarstvennichestvo), referring to a significant role for the state in directing and regulating society, though he cautions, not the detriment or exclusion of democracy; and social solidarity, or the recognition of the collectivist nature of Russian life. ${ }^{13}$

These values seem to resonate with the general population as they correspond with survey results collected by Pål Kolst $\varnothing$ and Helge Blakkisrud from their June 2000

\footnotetext{
${ }^{10}$ Tim McDaniel, The Agony of the Russian Idea (Princeton: Princeton University Press, 1996), 11.

11 Ibid., 24.

12 Ibid., 43.

${ }^{13}$ Vladimir Putin, "Rossiia na rubezhe tysiachetletii," Nezavisimaia gazeta, December 30, 1999, http://www.ng.ru/politics/1999-12-30/4_millenium.html.
} 
survey of 1200 Russian respondents, using standard techniques of sampling and selection. 72 percent of the respondents agreed that Russia should have a state ideology and when asked what the most important elements of it would be 41.0 percent selected "a combination of universal values and traditional Russian values," 36.6 percent selected “traditional Russian values," 36.6 percent selected "the combined national values of all the peoples of Russia," and 23.7 percent selected "gosudarstvennost' and patriotism."14 Although the choices in this question were clearly influenced by Putin's program, the high rate of responses to elements reflecting Russia's national character suggests that Russians do agree with Putin's assessment of the Russian idea. ${ }^{15}$ In terms of whether the state should play an important role in the lives of citizens, Samuilov notes that in a contemporary public opinion study (source not provided), 67 percent of respondents suggested that they would need outside support in their lives, by either the state or their community, because they could not survive on their own. ${ }^{16}$

\section{$\underline{\text { Public Opinion in Russia }}$}

In light of Russia's political culture, which is community and state oriented, an important question becomes whether Russians want their country to be democratic. Joan DeBardeleben and her Russian colleagues asked this question to a representative sample of respondents in both 2000 and 2004. They conducted interviews in three regions of Russia-Orel (southwest of Moscow), Stavropol (in the Caucasus region), and Nizhnii Novgorod (southeast of Moscow) - using multi-stage stratified random sampling

\footnotetext{
${ }^{14}$ Pål Kolstø, "Values and State Ideology in Post-Communist Russia," in Nation-building and Common Values in Russia, ed. Pål Kolstø and Helge Blakkisrud (Lanham, Maryland: Rowman \& Littlefield Publishers, Inc., 2004), 330-331.

${ }^{15}$ The next highest response (7.7 percent in agreement) was toward incorporating communism into the state ideology.

${ }^{16}$ Samuilov, "O Rossii kak o severnoi tsivilizatsii," 32.
} 
procedures. When asked specifically about whether they supported the introduction of democracy in Russia, over 70 percent of respondents in both years agreed. However, it is interesting that in 2000 , an average of 73.2 percent supported democracy in Russia, while in 2004 , the number dips slightly to 70.7 percent. $^{17}$ At the same time, the percentage of Russians in these regions that were dissatisfied and more dissatisfied than satisfied with the level of democracy in Russia reduced from 92.3 percent in 1998 , to 87.6 percent in 2000 (shortly after the election of Putin), and then to 83.6 percent in 2004 (shortly after Putin's re-election). ${ }^{18}$

Although it is clear that those surveyed were not pleased with the level of democracy in Russia, the percentage of people in favour of democracy suggests that there is a desire to see democracy improved in Russia, not done away with. Interviews carried out by Ellen Carnaghan echo this sentiment. Carnaghan conducted intensive interviews of open-ended questions with sixty citizens, representing a broad spectrum of ages and socio-economic brackets, from both rural and urban areas across Russia. Although her sampling size is too small for the results to be representative of the Russian population, she opted for this kind of ethnographic research in order to understand better the responses given by Russians to mass survey questions. The majority of her respondents were dissatisfied with their current political system, but at the same time, were not particularly keen to change it. Carnaghan explains, "The prevailing sense among my Russian respondents is that their political institutions are more or less appropriate; they

\footnotetext{
${ }^{17}$ Joan DeBardeleben, "Putin's Federal Reforms and Public Opinion," (paper presented at the annual meeting of the American Association for the Advancement of Slavic Studies, Boston, USA, December 4-7, 2004), table 4.

${ }^{18}$ Ibid., table 5 .
} 
just do not work very well."19 Furthermore, Carnaghan suggests that her interviews show that Russians like the ideal of democracy, as they would like more and better representation in government, but dislike how democracy has developed in Russia and thus, "undemocratic" orientations can be explained as the result of malfunctioning democratic institutions. ${ }^{20}$ This is perhaps why, in a January and February 2005 survey conducted by the Institute of Complex Social Research (IKSI) at the Russian Academy of Sciences, including 1750 respondents from all of Russia's regions, respondents reacted with scepticism and negativity when presented with the notion of the practical realization of democratization in Russia. ${ }^{21}$

In fact, survey results indicate that Russians have other priorities ahead of democratization. This sentiment is apparent in a February 2005 survey conducted by the All-Russian Center of Public Opinion Research (VTsIOM), which according to the Center's website, conducts surveys using multi-stage stratified random sampling that is representative of the Russian adult population by sex, age, employment status, federal district, and population density. ${ }^{22}$ When asked, "which ideas could unite Russian society today," the most popular responses were the ideas of stability (44 percent), law and order (37 percent), and a strong state ( 35 percent). Only 11 percent of the respondents indicated the further development of democracy. ${ }^{23}$ Furthermore, in the same survey, the interviewees were given a list of forty concepts and were asked to indicate whether they

\footnotetext{
${ }^{19}$ Ellen Carnaghan, Out of Order: Russian Political Values in an Imperfect World (University Park, Penn.: The Pennsylvania State University Press, 2007), 227.

${ }^{20} \mathrm{Ibid}$., 267-268.

${ }^{21}$ Institut kompleksnykh sotsial'nykh issledovanii RAN, "Perestroika glazami rossiian: 20 let spustia," Sotsis sotsiologicheskie issledovaniia 9, no. 257 (2005): 31.

${ }^{22}$ VTsIOM, "Obshcherossiiskii omnibus (ekspress)," http://wciom.ru/issledovanijapolitika/obshcherossiiskii-omnibus.html.

${ }^{23}$ Vladimir Petukhov, "Perspektivy transformatsii: Dinamika ideino-politicheskikh predpochtenii rossiian," Svobodnaia mysl' 6, no. 1556 (2005): 62.
} 
think positively or negatively about each. The most positively appraised concepts were order (61 percent), justice (53 percent), and freedom (43 percent). ${ }^{24}$

Carnaghan's interviews shed light on what Russians mean by these terms. Many of her respondents indicated that fairly applied, sound, and respected laws are weak or non-existent in Russia and it is these kinds of laws that are crucial to making democracy function properly. ${ }^{25}$ Carnaghan determines that when Russians speak about a strong government, they are referring to a government that can enforce laws (and therefore create order) and protect the rights of citizens, rather than to an authoritarian form of rule. $^{26}$ In this sense, a strong state is synonymous with order, as both refer to laws that are established and enforced. ${ }^{27}$ However, Carnaghan observes that the respondents are less likely to have a democratic orientation and more likely to define order with authoritarian overtones if they perceived their lives and the conditions around them as chaotic, whereas the more democratically-oriented respondents considered order as a basis for freedom. ${ }^{28}$ Carnaghan also notices that when speaking of freedom, the respondents linked it to material security, rather than to independence or the ability to choose. $^{29}$ This is perhaps why more than 30 percent of respondents of nationwide surveys in 2000 and 2004 associated democracy with economic prosperity. ${ }^{30}$ If Carnaghan's findings do reveal how a majority of Russians feel, democracy would then be a high priority, since it would be in keeping with order in society and economic improvements, both of which are highly valued. If this is true, then possible reasons as to

\footnotetext{
${ }^{24}$ Petukhov, "Perspektivy transformatsii," 62.

${ }^{25}$ Carnaghan, Out of Order, 98.

${ }^{26}$ Ibid., 98.

${ }^{27}$ Ibid., 181.

${ }^{28}$ Ibid., 157.

${ }^{29}$ Ibid., 33.

${ }^{30}$ Yuri A. Levada, "What the Polls Tell Us," Joumal of Democracy 15, no. 3 (2004): 45.
} 
why democratization rates poorly on surveys are because it is associated with the reforms of the 1990s and because it implies a move towards a western (and therefore liberal) system.

Since Russians are generally supportive of democracy, but dissatisfied with how it has turned out in Russia, it would be natural to assume that Russians would be dissatisfied with their head of state, since he had the power and chance to ameliorate the situation. However, opinion poll ratings do not suggest this. While other institutions of the Russian government receive very low approval ratings, President Putin's approval remained high for both his terms. These results are shown in polls conducted by VTsIOM. In 2000, Putin's approval ratings between March and July averaged around 70 percent and even his poor handling of the Kursk emergency in August of that year ${ }^{31}$ only dropped his approval ratings by 5 to 10 percent. $^{32}$ In January 2002, Putin's support rating was at 75 percent, while the Russian government only received 40 percent approval and the Prosecutor General received even less at 36 percent. $^{33}$ In January 2005,65 percent of respondents agreed with the actions of President Putin, while only 27 percent agreed with those of the Russian government, 23 percent with the State Duma, and 16 percent with those of political parties. ${ }^{34}$ Using Levada Center data from a multi-stage stratified survey conducted in April and May 2007, which is representative of the Russian population, Lilia Shevtsova notes a similar trend, where despite the feelings toward other aspects of Russian life, Putin's support remained strong. She cites that 65 percent of the

${ }^{31}$ On August 12, 2000, a chemical explosion occurred on the military submarine Kursk. Although British and Norwegian teams offer to help rescue those onboard, the Russian government refused this offer and failed to conduct a timely rescue, which resulted in the deaths of all those onboard.

${ }^{32}$ VTsIOM, "Press-vypusk: 28 sentiabria 2000 goda," http://wciom.ru/arkhiv/tematicheskiiarkhiv/item/single/454.html?no_cache $=1 \& \mathrm{cHash}=32 \mathrm{fc} 680393$.

${ }^{33}$ VTsIOM, "Press-vypusk: 1 fevralia 2002 goda," http://wciom.ru/arkhiv/tematicheskiiarkhiv/item/single/282.html?no_cache $=1 \& \mathrm{cHash}=13 \mathrm{ffe} 1 \mathrm{~d} 426$.

${ }^{34}$ Petukhov, "Perspektivy transformatsii," 66. 
respondents were dissatisfied with the country progress, while 14 percent thought their country's economic situation would worsen and 69 percent thought it would neither improve nor deteriorate, yet Putin's support rating was at 77 percent. $^{35}$ These ratings increased a few months later, when a July 2007 Levada Center poll placed Putin's approval rating at 85 percent, while only 41 percent satisfied with their country's situation. $^{36}$

What then makes Putin so popular? Is it because he is perceived as the executor of Russia's general will? This is difficult to say for certain, since Russians are sceptical as to how representative their government is. Stephen Whitefield conducted national, representative surveys in 1993, 1995, 1996, 1998, 2001, 2003, and 2007 to, among other goals, determine trends in Russian's evaluations of democracy in their country. ${ }^{37} \mathrm{He}$ notes that the feelings toward the government's responsiveness and towards majoritarianism stayed fairly stable over the years. ${ }^{38}$ He writes, "Russians appear very critical of government responsiveness: when they were asked whether officials care, the high point was 2.10 (in 1996), and whether they had a say in what governments did, the high was 2.43 (in 2001). On majoritarianism [whether the government's policies are in accord with the wishes of the majority], the results were also quite negative, with a high of 2.29 in 2003." 39 Even though Whitefield's data show that the opinions of whether the government follows the general will were better under Putin than Yeltsin, the overall low ratings suggest that Russians do not believe that Putin's government listens to their

\footnotetext{
${ }^{35}$ Lilia Shevtsova, Russia - Lost in Transition (Washington: Carnegie Endowment for International Peace, 2007), 271-272.

${ }^{36}$ Ibid., 320.

${ }^{37}$ Whitefield coded his responses on a scale of 0 to 5 , with 0 being highly unfavourable and 5 highly favourable responses.

${ }^{38}$ Stephen Whitefield, "Russian Citizens and Russian Democracy: Perceptions of State Governance and Democratic Practice, 1993-2007," Post-Soviet Affairs 25, no. 2 (2009): 100.

${ }^{39}$ Ibid., 100.
} 
wishes. Carnaghan notes a similar feeling in her respondents, where there was general agreement that ordinary citizens could not compel their government to take action. ${ }^{40}$ However, Carnaghan's interviews also reveal that many of the respondents trusted Putin, believed he had good intentions while leading the country, and had the best interests of Russia in mind, unlike the State Duma or the president's closest advisors. ${ }^{41}$ Indeed, Levada Center surveys show that for most of Putin's two terms as president, his trust ratings exceeded 70 percent. ${ }^{42}$ Based on this information and Putin's constantly high approval ratings, it is possible that Russians do see Putin as a leader who if not responsive to the general will, at least will govern according to the best interests of the country.

Another possibility to explain Putin's popularity is that he brought Russia closer to the Russian understanding of democracy. This is demonstrated through the survey conducted by IKSI, as Putin was credited for establishing some degree of order and economic prosperity. The respondents were asked to indentify under which leader Mikhail Gorbachev, Boris Yeltsin, or Vladimir Putin - various conditions were better. The largest grouping for the general economic system, quality of life, receiving pay and pensions, the international situation, the state of democracy, and fighting corruption in the bureaucracy were attributed to Putin. However, Gorbachev received the most responses for the safety of citizens, general psychological climate in Russia, conditions in the army, the court system, political activism of citizens and relations between nationalities within

\footnotetext{
${ }^{40}$ Carnaghan, Out of Order, 221.

41 Ibid., 93.

${ }^{42}$ Joan DeBardeleben, "Reflections on Prospects for Russian Democracy," in From Putin to Medvedev: Continuity or Change? ed. J.L. Black and Michael Johns (Manotick, ON: Penumbra Press, 2009), 15.
} 
Russia, while Yeltsin's time as president did not elicit any top responses. ${ }^{43}$ These results indicate that while there is not as much harmony in society as during the communist times, Putin has instead provided for a better economic and political situation.

DeBardeleben's research also indicates that in the three surveyed regions, the respondents perceived that Putin's government fought crime better than did the Yeltsin administration, created more economic activity, and marginally improved employment assurances. $^{44}$

From her interviews, Carnaghan notices that many of her respondents in 2000 liked Putin's “energy, vitality, youth, education, experience, and decisiveness," particularly in contrast to Yeltsin. However, by 2003, the respondents were less optimistic that Putin would be able to solve Russia's problems, since conditions had not improved enough under his leadership. ${ }^{46}$ Nevertheless, the respondents tended to agree that Putin reversed what they perceived as the worst transgressions of Yeltsin rule and started to create an economic system that could be beneficial to ordinary Russian citizens. ${ }^{47}$ This sentiment corresponds to the findings from IKSI, which suggest that many Russians believed their political and economic conditions were best under Putin. Furthermore, Carnaghan's interviewees did not think of Putin as either "... an autocrat or a savior, just a competent man with a sense of responsibility toward his people." ${ }^{48}$ This is perhaps why, when asked which leader deserves the most credit for Russia's attainment of democratic rights and freedoms by IKSI, Putin received 19 percent of the respondents'

\footnotetext{
${ }^{43}$ Institut kompleksnykh sotsial'nykh issledovanii RAN, "Perestroika glazami rossiian," 32.

${ }^{44}$ DeBardeleben, "Putin's Federal Reforms," table 2.

${ }^{45}$ Carnaghan, Out of Order, 91.

${ }^{46}$ Ibid., 92-93.

${ }^{47}$ Ibid., 149.

${ }^{48}$ Ibid., 92.
} 
support, which was more than either Gorbachev or Yeltsin (though 43 percent answered that Russia is not democratic). ${ }^{49}$ Furthermore, Levada Center results show that shortly after Putin's election in 2000, 29 percent of respondents considered him the leader of Russia's democratic movement. Interestingly, more Russians believed Putin to be the main democratic presidential candidate than the combined total of the leaders of the two parties perceived to be the most democratic in the West, Yabloko's Grigory Yavlinsky, whom 16 percent of respondents thought was the leader of the democratic movement, and the Union of Rightist Forces' Sergei Kirienko (12 percent). ${ }^{50}$

A possible explanation of this could be that Russians felt that there was no other viable candidate for the position of president and thus, Putin was their most democratic choice (compared to Vladimir Zhirinovsky and Gennady Zyuganov). Although discussing political parties and Duma elections, Carnaghan's respondents who related to the platforms of the liberal parties (Yabloko and the Union of Rightist Forces), often said they voted for "Putin's party" because they thought that was the party that would win." It is possible that a similar logic could apply to the presidential elections. Yuri Levada, director of the Levada Center, notes that of those who voted for Putin in 2004, 30 percent believed that he had successfully governed the country in his previous term, 39 percent believed that he would address problems faced by Russia if re-elected, while 29 percent felt that there was no other candidate running for president that they could put their hopes on. $^{52}$ Shevtsova also presents the possibility that Putin is the only viable candidate. She explains the discrepancy between Putin's popularity rating and the percentage of

\footnotetext{
${ }^{49}$ Institut kompleksnykh sotsial'nykh issledovanii RAN, "Perestroika glazami rossiian," 31-32.

${ }^{50}$ Levada, "What the Polls Tell Us," 50.

${ }^{51}$ Carnaghan, Out of Order, 147.

${ }^{52}$ Levada, "What the Polls Tell Us," 47.
} 
Russians who think he is a successful leader of Russia, citing the 2006 figures of 76 percent and 17 percent respectively (but not providing the survey source), by suggesting that people feel this way because there is no other serious contender for the role of president. ${ }^{53}$ The possibility that Putin's elections were not acts of the general will, but rather the only option for a democratic Russia brings up the importance of looking at elections.

\section{$\underline{\text { National Elections }}$}

In the span of Putin's two terms as president, four elections at the federal level occurred - two presidential and two parliamentary. ${ }^{54}$ The presidential elections garnered the most voter turnout, 68.6 percent on March 26, 2000 and 64.4 percent on March 14, 2004. Putin was the clear winner of these elections, receiving 53.4 percent and 71.9 percent of the votes, respectively. The runners-up in the elections were the candidates representing the Communist Party of the Russian Federation, Zyuganov in 2000 (29.5 percent of the vote) and Nikolai Kharitonov in 2004 (13.8 percent). The liberal candidates, Yavlinsky in 2000 and Irina Khakamada in 2004 (who ran as an independent, since the Union of Rightist Forces could not gather the necessary signatures to have her run as their representative), received 5.9 percent and 3.9 percent, respectively.

The parliamentary elections had slightly lower levels of participation, with 55.7 percent of eligible voters turning out on December 7, 2003 and 63.7 percent on December 2, 2007. In both of these elections, United Russia, a party that unwaveringly supports Putin, won the most seats, taking 38.2 percent of the votes cast in 2003 and 64.3 percent in 2007. Interestingly, a poll conducted after the 2007 election by the Levada Center

\footnotetext{
${ }^{53}$ Shevtsova, Russia - Lost in Transition, 282.

${ }^{54}$ The election results data were taken from the International Foundation for Electoral Systems' website, at www.electionguide.org.
} 
suggests that only one third of the respondents voted for United Russia based on its platform, while the remaining two thirds of United Russia voters supported the party because Putin headed the party list. ${ }^{55}$ As in the presidential elections, the party that received the second highest levels of support was Communist Party, winning 12.8 percent of the votes in 2003 and 11.6 percent in 2007. The Liberal Democratic Party of Russia, which contrary to its name runs on an extremist platform, won 11.6 percent of the votes in 2003 and 8.1 percent in 2007.

Looking at the remainder of the parties that won seats reveals the effects of the 2005 changes to the electoral rules, which will be discussed later on. In 2003, Rodina received 9.2 percent of the votes, the Union of Rightist Forces received 4 percent, and Yabloko received 4.4 percent, while independent candidates (who, after election, mostly proceeded to join United Russia) ${ }^{56}$ received 15.1 percent. Because elections to the Duma were based on a mixed party system, where half the seats were based on party-list proportional representation and the other half on single-member districts, all of the aforementioned parties received seats in the Duma. However, in 2007 when the competition was based solely on proportional representation, the only other party to win seats in the Duma was A Just Russia (a left of centre amalgamation of several smaller parties, including Rodina), which received 7.7 percent of the votes cast.

In addition to fewer parties in the Duma, another noticeable difference in 2007 was the absence of the "against all" option on the ballot (a holdover from Soviet elections, which was abolished by a United Russia sponsored bill in 2006). In the 2003

\footnotetext{
${ }^{55}$ Yuri Levada, "Dumskie vybory 2007: poslednie itogi (chast'i)," January 9, 2008, as cited in Joan DeBardeleben, "Russia's duma elections and the practice of Russian democracy," International Journal, (spring 2008): 288.

${ }^{56}$ Bryon Moraski, "Electoral System Reform in Democracy's Grey Zone: Lessons from Putin's Russia," Government and Opposition 41, no. 4 (2007): 539.
} 
parliamentary elections, 4.8 percent of the voters used this option (totalling 2851600 Russians) and in the 2004 presidential election, 3.5 percent of the voters expressed their dissatisfaction with the available choices. I expected that in the 2007 parliamentary election, either a significant number of ballots would have been spoiled by voters as a means of expressing their dissatisfaction with the available choices in lieu of the "against all" option or more voters would have chosen to not participate in the election than in years past. However, neither of these predictions materialized, as only 1.1 percent of the ballots were declared invalid and voter turnout was higher in 2007 than in 2003 . There are several possible explanations for this: More Russians were satisfied with their government in 2007 than before (which is supported by Putin's higher approval ratings at the end of his tenure as president than when he first came to office); although still dissatisfied, more Russians chose to keep these feelings to themselves and vote based on the options available to them; that the actual votes and voter number were incorrectly reported in order to show a greater degree of support for the incumbents or general accord in Russian society; or that United Russia's campaigns and pressure to obtain high levels of voter turnout were successful.

Based on the results of these four elections, several conclusions can be made of Russia's electoral system and, by extension, the state of its democracy. Firstly, elections occur on a regular basis with decent levels of participation, which means that the electoral process has become institutionalized in Russia. As Michael McFaul and Nikolai Petrov observe, "By 1999-2000 elections were no longer ad hoc weapons to be deployed or suspended for immediate political gain. Elections for the Duma and president were 
becoming normal, anticipated events of the political system., ${ }^{, 57}$ This is a positive step towards democracy, since elections are the main mechanism through which the popular control of the government can be achieved.

As previously mentioned, the electoral rules have changed in Russia under Putin's watch, which may cause some uncertainty regarding the institutionalization of elections. Some observers were sceptical of 2005 electoral changes, which switched the electoral system from a mixed-member format to proportional representation, raised the threshold for seats in the Duma from five to seven percent of the votes cast, prevents the formation of electoral blocs, increases state funding to parties represented in the Duma, and prohibits deputies from moving to a different party than the one that nominated them. Zoe Knox, Pete Lentini, and Brad Williams note that the electoral changes, “...may, on the surface, appear to militate against democrats, particularly in light of their poor performance in the 2003 Duma elections. Moreover, the new electoral infrastructure could greatly increase the representation of the existing parties of power." ${ }^{\text {58 }}$ However, they go on to suggest that these changes may actually help electoral democracy to flourish. Bryon Moraski agrees, arguing that the electoral reforms help Putin in the shortterm, by bettering the chances that United Russia can maintain control of the Duma until 2012, when Putin is again eligible to run for president. ${ }^{59}$ However, over time, he suggests that these changes will improve Russia's democracy since proportional representation, by its nature, will provide smaller, more narrowly focused political parties a better

\footnotetext{
${ }^{57}$ Michael McFaul, Nikolai Petrov, and Andrei Ryabov, Between Dictatorship and Democracy: Russian Post-Communist Political Reform (Washington: Carnegie Endowment for International Peace, 2004), 51. ${ }^{58}$ Zoe Knox, Pete Lentini, and Brad Williams, "Parties of Power and Russian Politics: A Victory of the State over Civil Society?" Problems of Post-Communism 53, no. 1 (2006): 4.

${ }^{59}$ Moraski, "Electoral System Reform in Democracy's Grey Zone," 549.
} 
opportunity to win seats and can better represent minority groups in parliament. ${ }^{60}$

Furthermore, the changes can encourage party development, by reducing the attractiveness of running as an independent candidate and providing disincentive to party fragmentation. ${ }^{61}$ Unfortunately, the benefits for minorities, particularly geographically based ones, may not materialize in Russia, since there is one electoral zone for the whole country and rules that prevent regional parties from competing in the elections.

Beyond the formal rules of elections, there should also be a formalized set of guarantees related to the democratic process. Here, we look to The Constitution of the Russian Federation. Chapter 1 article 3, lays out the basis for a democratic system:

1. The multinational people of the Russian Federation shall be the vehicle of sovereignty and the only source of power in the Russian Federation.

2. The people of the Russian Federation shall exercise their power directly, and also through organs of state power and local self-government.

3. The referendum and free elections shall be the supreme direct manifestation of the power of the people.

4. No one may arrogate to oneself power in the Russian Federation. Seizure of power or appropriation of power authorization shall be prosecuted under federal law. ${ }^{62}$

In this article, we see the enshrinement of popular rule through elections, which are declared the only legitimate means of ascending to power. Furthermore, article 32 , subsection 2 guarantees citizens the right to participate in referendums and elections (as a voter or a candidate), while article 19, sub-section 2 guarantees the equality of rights to all citizens, forbidding discrimination based on sex, ethnicity, nationality, language, place of residence, employment status, convictions/beliefs, or membership in public

\footnotetext{
${ }^{60}$ Moraski, "Electoral System Reform in Democracy’s Grey Zone," 542.

${ }^{61}$ Ibid., 552.

${ }^{62}$ The Constitution of the Russian Federation, art. 3, sec. 1. Available online and translated at http://www.departments.bucknell.edu/russian/const/ch1.html.
} 
associations. ${ }^{63}$ Thus, according to The Constitution, all people (and therefore all minorities) have the right to participate in elections. Andrei Melville suggests that the high participation rates in elections indicate that the electoral rights of minorities have not been discriminated against. ${ }^{64}$ Thus, according to The Constitution, Russia is a democracy based on elections in which all citizens can participate and where minorities are protected. As to the question of whether Russia has an agreed upon set of rules for the electoral process, it appears that Russia does meet the basic criteria and has a system (at least in theory) based on popular rule, equality, and freedom.

Theoretically, if Russians are unsatisfied with the conduct of the elections, they have the right to appeal to the country's judicial system. Article 46, sub-section 2 of The Constitution states, "The decisions and actions (or inaction) of state organs, organs of local self-government, public associations and officials may be appealed against in a court of law." 65 Under the purview of this law would be the right for a candidate or political party to appeal the results of an election, based on information of falsification or so on. However, in practice, the courts cannot be relied upon because they are controlled by the Kremlin. Mikhail Krasnov notes that:

...Russia does not yet have an accessible, genuinely independent, and effective system of justice that includes modern civil and criminal procedures that presume the equality of the parties involved and their right to contest. Nor does Russia have a comprehensive legal framework that encompasses fully fledged appellate courts, the circuit principle of court jurisdiction, and the diminished weight of publicity. The country is dominated by a repressive, militarized, Stalinist era law enforcement system. ${ }^{66}$

\footnotetext{
${ }^{63}$ The Constitution of the Russian Federation, art. 19 and 32, sec. 1.

${ }^{64}$ A. Iu. Melville, Politicheskii atlas sovremennosti (Moscow: MGIMO-Universitet, 2007), 234.

${ }^{65}$ The Constitution of the Russian Federation, art. 46, sec. 1.

${ }^{66}$ McFaul, Petrov, and Ryabov, Between Dictatorship and Democracy, 209.
} 
Because the courts are not developed enough to have independence, the government can interfere in judicial decision-making. A variety of formal and informal channels between the president and judiciary force the courts to comply with directions from the executive and even when legal decisions go against the executive's expectations, state authorities will routinely disregard them, since judges have no means to enforce their decisions. ${ }^{67}$ Furthermore, there is a legislative provision that allows for the removal of judges from their post, which stymies an autonomous judiciary, since the job security of judges is dependent on the favour of the president, thus increasing the likelihood of judicial compliance with the wishes of the administration. ${ }^{68}$ As such, politicians who wish to appeal how an election was carried out, particularly if they feel an unfair advantage was given to the candidates favoured by the Kremlin, face little likelihood of a sympathetic ear in court. For example, when presented with data that showed that the Union of Rightist Forces was cheated in vote counting, Khakamada dismissed the possibility of challenging the electoral commission in court, commenting, "We realize perfectly well that all this would make no sense." ${ }^{, 99}$ Thus, although there is technically a route for redress of wrongdoing in elections, it would appear that in actuality, the Russian court system fails to fulfil this role.

The second conclusion that can be drawn from the federal election results is not optimistic for Russian democracy. The landslide wins for Putin and United Russia suggest that elections in Russia are not as competitive as they could be. Even Melville and his team of researchers from the Moscow State Institute for International Relations

\footnotetext{
${ }^{67}$ McFaul, Petrov, and Ryabov, Between Dictatorship and Democracy, 78.

${ }^{68}$ Ibid., 78.

${ }^{69}$ M. Steven Fish, Democracy Derailed in Russia: The Failure of Open Politics (Cambridge: Cambridge University Press, 2005), 79.
} 
(MGIMO), who set out to rank countries in a manner that takes into account each country's unique national goals and priorities, history, culture, level of development, and socio-political trajectory (or in other words, in a way that avoids using ideological or stereotypical understandings of politics), note that Russia does not rank very high in its institutional basis of democracy. ${ }^{70}$ They purport that Russia has necessary, but insufficient institutions for stable democratic governance, which is reflected in Russia's ninety-third place out of one hundred ninety-one countries in the index of the institutionalized basis of democracy. Melville and his team suggest that Russia's ranking is in large part due to the low level of competition in presidential elections. ${ }^{71}$ As Iaroslav Shimov notes, Putin's elections in 2000 and 2004 were the first elections in post-Soviet Russia where the outcomes were known beforehand..$^{72}$

The lack of competitiveness does not come from a lack of democratic procedures, but rather from how elections are actually practiced. Russian elections are rife with examples of fraud and coercion. In Democracy Derailed in Russia, M. Steven Fish documents a number of different forms of electoral fraud. He cites several investigations by the English language newspaper, The Moscow Times, which shows that the official numbers for various electoral precincts do not match those recorded by the precincts themselves after the results were tallied locally. ${ }^{73}$ Furthermore, there was an unusual increase in the number of eligible voters over a span of fourteen weeks between the 1999

\footnotetext{
${ }^{70}$ The researchers gathered data on over one hundred variables for every member country of the United Nations, then used discriminating analysis to place on countries on a continuum for five different indexes: state system, internal and external threats, potential for international influence, quality of life, and the institutionalized base of democracy. These rankings could then be used in cluster analysis, to better determine how countries compare to one another. (Politicheskii atlas sovremennosti, 7-21.)

${ }^{71}$ Melville, Politicheskii atlas sovremennosti, 233.

${ }^{72}$ Iaroslav Shimov, "Epokha Vladimira Putina i transformatsiia rossiiskoi gosudarstvennosti," Neprikosnovennyi zapas 57, no. 1 (2008).

${ }^{73}$ Fish, Democracy Derailed in Russia, 34-35.
} 
parliamentary and 2000 presidential elections, when 1.3 million new voters appeared on the voter registry, while there was no plausible demographic reason for this. Fish explains this increase as the inclusion of "ghost voters" to bolster presidential support numbers. ${ }^{74}$ Although anecdotal, Fish includes several comments from election observers and voters who recalled incidents of ballot stuffing, the incorrect filling out of protocol forms (which record the number of votes for each candidate), the inclusion of fake people on the voter registry, and a scheme whereby Putin supporters near voting stations in Tatarstan offered voters a small sum of money to deposit an already marked ballot and return to them a blank ballot to be filled out in favour of Putin for the next voter. ${ }^{75}$ Believing there to have been fraud in the 2003 Duma elections, the Communist Party conducted a recount. Although the Communist Party's performance matched the official count, the recount showed that both Yabloko and the Union of Rightist Forces had more votes cast for them than officially recorded-6.0 percent and 5.1 percent-which would have brought both parties past the 5 percent threshold and given them better representation in parliament. ${ }^{76}$

Apart from electoral fraud, a number of scholars point to problems leading up to elections in Russia, which make the competition less fair, and by extension, less competitive. The main concern of McFaul and Petrov in relation to Russian elections is the use of state resources in controlling the outcomes of elections, particularly the state's control over the media. ${ }^{77}$ They argue that beginning with the 1999/2000 electoral cycle, the Kremlin began to actively participate in the race by carrying out negative advertising

\footnotetext{
${ }^{74}$ Fish, Democracy Derailed in Russia, 39.

${ }^{75}$ Ibid., 41-43.

${ }^{76}$ Ibid., 78.

${ }^{77}$ McFaul, Petrov, and Ryabov, Between Dictatorship and Democracy, 53-54.
} 
toward the competitors of Putin and Unity (which later became United Russia) and using its financial resources (which were far greater than those of any other party or candidate) to support its desired candidates. ${ }^{78}$ Stephen White and Sarah Oates observe that, "The Duma campaign, in particular, marked a new low, with state television accusing the Kremlin's main challengers of being criminals, even accessories to murder, and accomplices of foreign powers, particularly Israel and the United States. ${ }^{, 79}$ Others accuse the Kremlin of restricting the sources of information available to citizens, which can assist voters in making informed decisions at the polls. Fish suggests that it has become increasingly difficult to find points of view different from the state's position in the media since the start of the 2000s. ${ }^{80}$ Alexei Simonov, head of the Glasnost Foundation, observes, "News on these four channels [the major channels of Russian television, First, Third, Russian, and NTV] is all very similar. If not as close as identical twins, it is like brothers and sisters who were born and brought up in one home with the same clear, unambiguous values and day-to-day codes of behaviour." ${ }^{81}$ He posits that these similarities are a result of the fact that the Kremlin launched a successful campaign to do away with independent media by assuming control of the channels and by intimidating oligarchs who control newspapers with the threat of losing their assets if they challenge the government's positions. ${ }^{82}$

Another means through which the government can influence the information available to voters is through complex legislation and the judicial system. Joel C. Moses

\footnotetext{
${ }^{78} \mathrm{McF}$ aul, Petrov, and Ryabov, Between Dictatorship and Democracy, 51.

79 Stephen White and Sarah Oates, "Politics and the Media in Postcommunist Russia," Politics 23, no. 1 (2003): 34.

${ }^{80}$ Fish, Democracy Derailed in Russia, 72.

${ }^{81}$ Alexei Simonov, "Media as Mouthpiece," Index on Censorship 4, (2005): 81.

${ }^{82}$ Ibid., 80.
} 
notes that the "widespread use of law and courts as political weapons by public officials against their opponents" has resulted in self-censorship by the media and NGOs. ${ }^{83}$ To demonstrate why self-censorship has taken root in Russia, Andrei Ryabov cites examples of administrative and legal barriers to the freedom of the press. Such state tactics as prohibiting the publication of certain journalistic undertakings, restricting public access to state documents, and outright murder and intimidation of journalists, ${ }^{84}$ create a climate of fear and complacency, thus coercing independent organizations to obey the president's wishes. Legal barriers can also be used to control which candidates and parties are presented to voters. DeBardeleben comments that:

Outspoken critics of Putin and United Russia, such as Vladimir Ryzhkov (whose Republic Party of Russia was denied registration for having too few members) as well as former prime minister Mikhail Kasyanov and Garry Kasparov (associated with the non-electoral public movement, The Other Russia) had neither adequate public support nor were they granted legal standing to pose an electoral challenge. ${ }^{85}$

Fish notes that those who disqualify candidates based on political motivations, a common strategy to manipulate the choices available to voters, are often the same people who conduct electoral fraud-the electoral commissions and regional heads. Furthermore, he points to the complacency of the courts in allowing candidates to be disqualified without a legitimate basis. ${ }^{86}$ This arbitrary exclusion of political candidates presents a problem for the protection of minorities - in this case, political ones. If unfavourable political positions to those in power are marginalized, then this means that those who support such

\footnotetext{
${ }^{83}$ Joel C. Moses, "Russia's Struggle for Democracy," in Russia's Policy Challenges: Security, Stability, and Development, ed. Stephen K. Wegren (Armonk, N.Y.: M.E. Sharpe, Inc., 2003), 168.

${ }^{84}$ McFaul, Petrov, and Ryabov, Between Dictatorship and Democracy, 183.

${ }^{85}$ Joan DeBardeleben, "Russia's duma elections and the practice of Russian democracy," International Journal, (spring 2008): 285.

${ }^{86}$ Fish, Democracy Derailed in Russia, 66.
} 
positions are not on an equal standing with "acceptable" parties and that their freedom to participate and the freedom of voters to choose during election periods are limited.

A final point in looking at elections is to examine whether ordinary Russians are able to express their views freely, including the ability to make their own decisions when voting. Aleksei Kiva purports that the laws on extremism and inflaming social hatred have eliminated pluralism and the freedom of speech in Russia. In addition to citing examples of authors and artists who have been prosecuted under these laws and their works banned, he cautions that criticising the government or its ministers is punishable of three to seven years in prison, as is criticising poor performance in international relations or exposing Russia's social problems to the world. ${ }^{87}$ There are also restrictions on public associations, which can inhibit citizens from joining such groups or receiving information from them. An example of such restrictions is the new registration process for foreign NGOs, which forced seventy-seven organizations (including Amnesty International and Human Rights Watch) to cease their activities until they were able to properly register. Furthermore, this legislation gives officials the authority to disallow an NGO from operating in Russia if they suppose that the organization's goals conflict with "Russia's national interests and 'morals.",88

In contrast to the reports that make it seem as though Russians live in a society where they are unable to express any opinions different from those of the state, Carnaghan's respondents did not feel that the limits on the press and criticism affect their own levels of freedom. ${ }^{89}$ Moreover, the respondents that Carnaghan classified as having

\footnotetext{
${ }^{87}$ Aleksei Kiva, "Kakoi rezhim formiruetsia v Rossii?" Svobodnaia mysl' 12, no. 1583 (2007): 6.

${ }^{88}$ Nabi Abdullaev and Anastasiya Lebedev, "77 NGOs Forced to Suspend Activities," The Moscow Times, 20 October 2006, 1.

${ }^{89}$ Carnaghan, Out of Order, 211.
} 
a middle-level understanding of politics commented that there is less reason to fear arbitrary actions by their contemporary state than during the communist years and that people are free to complain about the government in public. ${ }^{90}$ Whitefield provides a similar observation, noting that in survey responses, Russians are can be highly critical of their state, its institutions, and their government, so there is no reason to suspect that citizens are becoming less willing to express their opinions under Putin. ${ }^{91}$ By extension, if citizens are willing to express their opinions to interviewers, why would they not feel the same way when voting? There are also examples of public protest that influenced particularly policies of the Putin administration. Shevtsova recalls that when the government tried to change the provision of welfare benefits, widespread protest forced the cancellation of the plan and caused the state to "[throw] millions of extra dollars into pacifying [the protesters]. ${ }^{, 92}$ In this sense, it seems that the opinions of commentators and ordinary Russians on the restrictions of liberty in Russia do not match, whereby reports on the clampdown on dissent seem exaggerated compared to the everyday experiences of citizens.

As previously mentioned, the government has a firm hold on media in Russia; however, the extent to which the media shapes Russians' opinions is a nebulous area. Although the media can play an important role in shaping values through concealing the coercive power of the state and transmitting reference points (ideas, images, problemsolving strategies) for viewers to interpret and react to information, ${ }^{93}$ people are not

${ }^{90}$ Carnaghan, Out of Order, 212.

${ }^{91}$ Whitefield, "Russian Citizens and Russian Democracy," 109.

${ }^{92}$ Shevtsova, Russia-Lost in Transition, 274.

${ }^{93}$ Sarah Oates, "Media, Civil Society, and the Failure of the Fourth Estate in Russia," in Russian Civil Society: A Critical Assessment, ed. Alfred B. Evans, Jr., Laura A. Henry, Lisa McIntosh Sundstrom (Armonk, N.Y.: M.E. Sharpe, 2006), 58. 
completely passive viewers and are capable of critically evaluating what they see on television. Considering that a large proportion of Russians were raised during the Soviet period when all media outlets were state controlled, it is likely that a fair number of these citizens have developed keen discernment skills for the interpretation of mass media messages. This sentiment is supported by focus group participants, who, when asked if biases in the media upset them, suggested to the facilitator that the viewer should be able to distinguish the falsities from the truth and that, "... in between the words, you can find what is really going on. Only it is difficult.. ${ }^{, 4}$ Furthermore, additional findings from these age-divided focus groups, which were conducted in three cities (Moscow, Ulyanovsk, and Voronezh) show that many Russians realize and anticipate television stations to be biased toward the interests of their benefactors and do not seems bothered by this. ${ }^{95}$ However, as Ellen Mickiewicz points out, personal deduction skills are not faultless. It is possible that, although people like to present an appearance of autonomy from outside influences, they are not capable of spotting all attempts to shape their views. Additionally, people may subconsciously receive information from the television, even if they are not giving it their full attention. ${ }^{96}$ Furthermore, when asked where they get their information for voting, 43 percent of respondents (the largest group) said they rely primarily on their own experiences and not on the media. ${ }^{97}$ Thus, it is difficult to judge to what degree Russians vote based on the messages they receive from media sources.

\footnotetext{
${ }^{94}$ Sarah Oates, Television, Democracy and Elections in Russia (London: Routledge, 2006), 50.

95 Ibid., 48.

${ }^{96}$ Ellen Mickiewicz, "The Election News Story on Russian Television: A World Apart from Viewers," Slavic Review 65, no. 1 (2006): 13.

${ }^{97}$ Christopher Marsh, "The Challenge of Civil Society," in Russia's Policy Challenges: Security, Stability, and Development, ed. Stephen K. Wegren (Armonk, N.Y.: M.E. Sharpe, Inc., 2003), 153.
} 
Overall, in terms of the freedoms that Russian citizens have at elections times, it is clear that they are no longer living in a totalitarian state and that they do hold a variety of opinions on political matters. It is also clear that the state plays a role in shaping the options available to citizens and even in ensuring that elections have favourable outcomes to the incumbents. It is interesting to note, however, that many observers believe that the electoral manipulation that occurred would not have changed the outcome of who won, since Putin (and by extension, United Russia) are genuinely popular. ${ }^{98}$ Furthermore, it is also not clear that the state's influence is unwelcomed by the majority of citizens, based on Russia's political culture. For example, a VTsIOM survey in March 2000 reveals that 55 percent of Russians wanted Putin to strengthen the state's control over mass media. ${ }^{99}$ Based on the previous discussions, the next chapter suggests whether Russia under Putin can be considered democratic.

\footnotetext{
${ }^{98} \mathrm{McFaul}$, Petrov, and Ryabov, Between Dictatorship and Democracy, 51, and DeBardeleben, "Reflections on Prospects for Russian Democracy," 13.

${ }^{99}$ Marsh, "The Challenge of Civil Society," 152.
} 


\section{Conclusion}

At the outset of chapter four, I laid out criteria for evaluating whether a country would be democratic, and in particular, criteria for evaluating whether popular rule, equality, and freedom are present in the subtype of consensus democracy. Before evaluating how well Russia under Putin meets those criteria, I would like to clarify a point regarding consensus democracy. One of the major purposes of this thesis is to define democracy in such a way that adjectives would not be necessary to qualify it; a country would either be democratic or not. ${ }^{1}$ In particular, conceiving of democracy in such a way is meant to counteract how, when speaking of democracy, many people have liberal democracy in mind. In essence, I wish to challenge the implicit ranking system of adjectival democracies, where liberal democracy reins supreme. This is not to say that democracy should never be qualified by an additional term. Particularly in comparative politics, being able to distinguish between forms of democracy is valuable. It is in this use- the description of a specific variant of democracy in contrast to liberal democracy - that I use the term consensus democracy.

To evaluate whether Russia under Putin was a democracy, we must look at the three major elements of democracy - popular control of the government, political equality, and freedom. It must be kept in mind, however, that no state is perfect or can obtain the absolute democratic ideal. As such, a slight infraction by the government or society in its policies toward the core elements of democracy should not automatically disqualify a country from being democratic. Although I do not have any scientific

\footnotetext{
${ }^{1}$ This is not to mean that a state could not be democratizing, but rather that when evaluating a state against the three elements of democracy alone, then only a static assessment of the state's system is possible. In order to make an assessment of democratization, a comparison of the criteria at a minimum of two different times would be necessary.
} 
measurement upon which to base such judgements, I keep the examples of what are generally considered established democracies (and their faults) in mind when assessing Russia. Since the general will and by extension, popular control, are the crucial aspects as to whether a country could be considered democratic in terms of achieving consensus democracy and thus will lead to the most involved discussion, the criterion of popular control will be looked at last.

\section{Freedom in Russia}

According to the second chapter of The Constitution of the Russian Federation, "The Rights and Liberties of Man and Citizen," Russian citizens are guaranteed "basic rights and freedoms," including the right to life, movement, personal convictions, free speech, and to participate in the forming of governments, etc., with special attention paid to protecting the rights of minorities. ${ }^{2}$ In practice, Russians do have personal freedom, as they are able to make meaningful choices in their lives regarding their private issues, such as families, occupations, and personal interests, without state involvement. This is supported by the fact that when interviewed, Russians feel that they have more freedom than they did under the communist regime. However, the disorder that is felt in society from the social and economic chaos following the dissolution of the Soviet system and "shock therapy" has made it difficult for many to practice the freedoms to which they are entitled to a full extent. As Ellen Carnaghan's respondents often pointed out, financial resources are vital to freedom, since living in poverty makes it difficult to enjoy concrete freedoms. ${ }^{3}$ Furthermore, there are a number of government infringements on freedom,

\footnotetext{
${ }^{2}$ The Constitution of the Russian Federation, art. 17-64, sec. 1. Available online and translated at http://www.departments.bucknell.edu/russian/const/ch2.html.

${ }^{3}$ Ellen Carnaghan, Out of Order: Russian Political Values in an Imperfect World (University Park, Penn.: The Pennsylvania State University Press, 2007), 213.
} 
such as media control and restrictions on civil society and dissident groups. Such restrictions, however, do not affect ordinary Russians on a day-to-day basis. The majority of Russians can gather to protest or criticize their government without any repercussions by the state. Although there are certain high-profile incidences of politically motivated oppression (such as the murder of journalist Anna Politkovskaya and the incarceration of Mikhail Khodorkovsky), on the whole, Russians do have the freedom that citizens living in a democracy should.

Equality

Unfortunately, due to the scope of this thesis, it is impossible to discern whether Russians have the necessary equality for a democracy. In order to address more adequately this question, it would be necessary to look beyond elections and voting to see the effects of, for example, discrimination and poverty in the country. Furthermore, since Russia is a multiethnic country, it is impossible to say without further research whether there is equality between or within these nationalities. Nevertheless, such problems as racism and discrimination plague even well established democracies (including France's Muslim population, African-Americans, and Aboriginals in Canada), so it becomes extremely complex and difficult to judge whether a country is democratic based on a macro-examination and comparison of equality. That being said, looking specifically at elections and whether voters have equality within the electoral process are good starting points for judging democracy, since elections are one of this system's formative institutions.

As with freedom, Russians are guaranteed equality under their Constitution. At election times, all citizens of the age of majority, except prisoners (which is a standard 
exception in democratic countries) are allowed to run for a position and/or vote for the candidates they desire. There do not seem to be large-scale reports of particular ethnicminority groups being refused the right to vote and the high turnout across the country on voting days suggests that there are no such barriers in place, which can be used as evidence that there are protections for ethnic minorities. However, political minorities do seem to be in a disadvantaged position. Cumbersome legislation provides a number of different loopholes with which to disqualify particular parties or candidates and examples of electoral fraud reduce the chances that parties not favoured by the Kremlin will receive an accurate count. Based on this, it is difficult to suggest whether there is enough equality in Russia for it to be democratic, particularly since infringements against equality can affect the outcome of elections.

\section{$\underline{\text { Popular Control of the Government }}$}

There are three major questions to be asked in order to determine if the population has control over its government and state policies, in accord with consensus democracy. Do Russians want to live in a democracy? Do government officials adhere to a democratic line? Does the government follow the general will of its citizens? In order for a state to be considered democratic, the answer to all three of these questions should be yes. Not only must both the governed and the governors have the goal of democracy in society, but the actions of the state must also match with democratic standards. Whether the government actually submits to its population's directives is more telling of democracy and the state's intentions than only its words.

In answer to the first question, I believe that Russians do want to live in a democratic state and support the overarching ideals of democracy. Public opinion 
research shows continued support for democracy, while ideals such as freedom often evoked positive reactions. That being said, many Russians are also dissatisfied with how their state serves them and operates on a daily basis. Of particular concern to many is the lack of order, which they perceive to be pervading many aspects of life, as evidenced by the high positive response to ideas such as order and stability. Above all, it is this missing sense of order that makes many Russians feel as though they are not currently living in a democracy.

The Russian government also makes no secret about its democratic intentions, as demonstrated through Putin's discussions of democracy. At a press conference in 2005, when asked about Russia's commitment to democracy, he responded:

First, we are not going to try to invent any kind of special Russian democracy; we will remain committed to the fundamental principles of democracy that have been established in the world. But, of course, all the modern institutions of democracy, the principles of democracy, should fit with Russia's current state of development and with our history and our traditions. There is nothing unusual in this. Each country gives these fundamental principles its own embodiment. ...There may be some differences in the way the main democratic institutions operate, but when it comes to the fundamental principles, we will implement them in the form in which they have been developed by modern, civilized society. As for the preceding period in our development,...despite the difficulties and problems engendered by the changes taking place in Russia, the politicians of that time gave the people what is most important - freedom. But I believe that a lot of people will agree with me when I say that establishing democratic principles should not cause the state to disintegrate or reduce the people to poverty. We believe, and I personally believe, that the implementation and the strengthening of democracy on Russian soil should not compromise the concept of democracy. It should strengthen statehood and it should improve people's lives. ${ }^{4}$

${ }^{4}$ President of Russia, "Press Conference on the Results of Russian-American Talks, Feb. 24, 2005," http://eng.kremlin.ru/text/speeches/2005/02/24/2307_type82914type82915_84525.shtml. 
In this excerpt, there are several noteworthy ideas. Firstly, Putin acknowledges that there are "fundamental principles" of democracy, which are vital to the proper functioning of a democracy, yet also adaptable to the specific situation of an individual country. Secondly, Putin explicitly rejects how a form of "democracy" was instituted and developed in Russia in the 1990s. Instead, he suggests that the opposites of the problems associated with the previous decade's democratization-a weakened state and social disparity—should be part of democratization and democracy in Russia, namely a strong state and tangible improvements to the lives of ordinary citizens. The major thrust of Putin's argument fits well with that of this thesis: Democracy does not necessitate a particular institutional arrangement, but rather is a system that respects and aims for popular control of the government, equality, and freedom. Putin's conception of democracy in Russia also fits with the general will of his electorate, specifically the longings for an increase in social order (by strengthening the state) and the betterment of the conditions in which people live (an increase in material standards and predictability in daily lives).

Although Putin does not provide concrete details of how such a democratic system should look in that interview, a question and answer period with the members of the Valdai Club in 2007 more clearly shows his conception of democracy in Russia. When asked which form of democracy he thinks is most suitable to contemporary Russia, Putin sums up his answer by saying, "Russia is a complex country and this is why, especially when we do not yet have a stable and developed multiparty system, the only 
suitable form of democratic power is strong and democratic presidential power." argument is vaguely reminiscent of Machiavelli's work, whereby a strong prince is needed to put the state into order before democratic instruments (in this case, a stronger multiparty system) can be instituted. Of course, this comparison of Putin to a 'prince' is not perfect, since Putin did incorporate democratic elements to his rule, while Machiavelli's prince would act only as an autocrat until the state was consolidated. Clearly, Putin's policies during his two terms as president demonstrated the "strong" part of this equation, but whether such rule is democratic leads us to the third question I posed earlier: Is such a manifestation of democracy the general will of Russians?

This is a complex question to answer. On one hand, having Putin as president of Russia seems to be the execution of the general will. Based on the percentage of Russians who voted for him and his continually high approval ratings, it appears that the wish of the majority of Russian citizens was to have Putin lead their country. This is further supported by the supposition that electoral fraud did not change the winner of elections. Nevertheless, electoral fraud and government manipulation of the political options available to citizens is particularly worrisome for democracy in Russia, since elections are the key mechanism through which citizens can indicate their will. By using administrative resources and legislative loopholes, the government is able to keep certain candidates and parties off the ballot, which limits the options of and therefore the freedom of citizens to choose. In addition, it is unclear whether the government's use of administrative resources would prevent another party that had a legitimate chance of

\footnotetext{
${ }^{5}$ President of Russia, "Meeting with Members of the Valdai International Discussion Club, Sept. 14, 2007," http://eng.kremlin.ru/speeches/2007/09/14/1801_type82917type84779_144106.shtml.
} 
winning an election from doing so. This doubt calls into question the degree to which elections in Russia are actually competitive.

A lot of noise is generated in the West about the Russian government's control of the media and how this shapes the political views of Russians, since not enough coverage is given to platforms critical of the Kremlin. In my opinion, this argument carries less weight than that of the use of administrative resources to shape opinions, since the extent to which the media influences Russians is unclear. Furthermore, as Noam Chomsky would attest, ${ }^{6}$ political incumbents in the West also control media outlets, which avoid presenting minority political viewpoints. One need only to think about, for example, the amount of media coverage the Green Party of Canada receives at election time to realize the hypocrisy of accusing the Russian media of not giving every party equal coverage.

On the other hand, whether Putin and his administration carried out the general will is more questionable. Citizens generally felt that their government was not responsive to their particular needs and even though there were some improvements in their quality of life under Putin (particularly in the economic and political spheres), overall satisfaction with their government and current situations were low. At the same time, Putin's support ratings suggest the possibility that throughout both his terms, he was doing something or some things that pleased the population. However, it is tenuous to link this approval to the execution of the general will. For example, if a child asks for cookies, but receives candy instead, he may still be happy, but his will was disregarded. Although we know through public opinion research that Russians wanted order and stability above all other political goals during Putin's terms as president, we cannot be

\footnotetext{
${ }^{6}$ See Edward S. Herman and Noam Chomsky, Manufacturing Consent: The Political Economy of the Mass Media (New York: Pantheon Books, 2002).
} 
certain that his approval ratings directly correlate with an increase in order and stability in respondents' lives. Perhaps some Putin supporters just want to be on the winning side of Russian politics. Furthermore, as pointed out in chapter four, it is possible that Russians support Putin because they view him as the only democratic candidate running who has a chance of winning. If this is so, it at least confirms that Russia's general will is for democratic leadership.

There is one further possibility that could support the argument that Putin is carrying out the general will of Russians, which goes back to the idea of Russian political culture. This line of thought follows as such: If Russians have been accustomed to following the directions of a strong leader and would thus want to continue being ruled in this manner, then the general will of Russians would be followed so long as the person who is leading them and making policy is desired and trusted to be in such a position. According to this hypothesis and Putin's support ratings, he would be enacting the general will. Unfortunately, due to the information available in the present research on public opinion in Russia, it is impossible to know for sure whether the general will was fully carried out while Putin was president of Russia. In order to find the precise answer to this question, representative national surveys would have to be conducted, asking specifically about the will of each citizen, his/her expectations for the government, and satisfaction levels with whether the government has followed his/her will. Other possibilities for research stemming from this project include looking at the legal system or political parties more closely to find out whether the general will can be implemented in Russia; examining other aspects of the Russian system to determine whether they are democratic; or applying the three elements of democracy to another country to test the 
validity of these criteria or whether this country is democratic. Another possibility would be to use the criteria to test whether a state is democratizing, which would involve looking at changes in attitudes and government policies over time.

Based on the research conducted in the paper, it is impossible to conclude that Russia under Putin was democratic. This is not to say that there were no democratic elements in Russia during Putin's rule, nor that the general will was never realized, but rather that his regime did not fully live up to democratic standards. Most troubling is the electoral fraud and lack of independent judiciary, which calls into question the basis of the system-whether Russians do have control over their government. However, to a certain extent, there was freedom, equality, and, when it came to the choice of leader, popular control in Russia from 2000 to 2008 . This conclusion contrasts greatly with the western assessments of Russia's "democratic backsliding" and "return to authoritarianism," which is largely due to the different standard of democracy applied. It appears then, that by focusing on the core elements of democracy, a more culturally sensitive conception of democracy is present, which is more universally applicable than liberal democracy. By returning democracy to its core elements, rather than thinking of it only in terms of a western-style of governance, a more nuanced picture of democracy in Russia emerges along with a greater possibility for future democratic improvements in the country, which would be derived from the will of Russian citizens rather than from the advice of western governments. 


\section{Bibliography}

Abdullaev, Nabi and Anastasiya Lebedev. "77 NGOs Forced to Suspend Activities." The Moscow Times, 20 October 2006.

Almond, Gabriel A. and Sidney Verba. The Civic Culture: Political Attitudes and Democracy in Five Nations. Boston: Little, Brown and Company, 1965. Althusser, Louis. "Ideology and Ideological State Apparatuses." In "Lenin and Philosophy” and Other Essays (1970). http://www.marxists.org/reference/ archieve/althusser/1970/ideology.htm (accessed Nov. 16, 2007).

Aristotle, The Politics of Aristotle. Oxford: Oxford University Press, 1958.

Balzer, Harley. "Managed Pluralism: Vladimir Putin's Emerging Regime," Post-Soviet Affairs 19, no. 3 (2003): 189-227.

Beetham, David. Democracy and Human Rights. Cambridge: Polity Press, 1999.

Bunce, Valerie. "The Political Economy of Postsocialism," Slavic Review 58, no. 4 (1999): 756-793.

Bykova, Marina. "Nation and Nationalism. Russia in Search of its National Identity." In Civil Society, Religion, and the Nation. Modernization in Intercultural Context: Russia, Japan, Turkey, edited by Gerrit Steunebrink and Evert van der Zweerde, 29-50. Amsterdam: Rodopi, 2004.

Carnaghan, Ellen. Out of Order: Russian Political Values in an Imperfect World. University Park, Penn.: Pennsylvania State University Press, 2007. Colton, Timothy and Cindy Skach. “The Russian Predicament," Journal of Democracy 16, no. 3 (2005): 113-126. 
Dahl, Robert A. Democracy and its Critics. New Delhi: Orient Longman Limited, 1991.

DeBardeleben, Joan. "Putin's Federal Reforms and Public Opinion." Paper presented at the annual meeting of the American Association for the Advancement of Slavic Studies, Boston, USA, December 4-7, 2004.

DeBardeleben, Joan. "Reflections on Prospects for Russian Democracy." In From Putin to Medvedev: Continuity or Change? Edited by J.L. Black and Michael Johns, 12-24. Manotick, ON: Penumbra Press, 2009.

DeBardeleben, Joan. "Russia's duma elections and the practice of Russian democracy," International Journal, (spring 2008): 275-290.

Dugin, Aleksandr. "Souchastie, sobornost', samobytnost'," Argumenty i fakty, no. 16 (2006): 4.

Duncan, Peter J.S. "Contemporary Russian Identity Between East and West," The Historical Journal 48, no. 1 (2005): 277-294.

Edinaia Rossiia, "Suverennaia demokratiia - eto effektivnoe samoupravlenie svobodnykh liudei," Edinaia Rossiia ofitsial'nyi sait partii, http://old.edinros.ru/print.html?id=120750 (accessed Oct. 22, 2009).

Eisenstadt, Shmuel N. "The Resurgence of Religious Movements in the Processes of Globalization - Beyond the End of History or the Clash of Civilizations." In Democracy and Human Rights in Multicultural Societies, edited by Matthias Koenig and Paul de Guchteneire, 239-250. Paris: UNESCO, 2007. 
Evans, Jr., Alfred B. “Vladimir Putin’s Design for Civil Society.” In Russian Civil Society: A Critical Assessment, edited by Alfred B. Evans, Jr., Laura A. Henry, and Lisa McIntosh Sundstrom, 147-158. Armonk, NY: M.E. Sharpe Inc., 2006.

Fish, M. Steven. Democracy Derailed in Russia: The Failure of Open Politics. Cambridge: Cambridge University Press, 2005.

Gill, Graeme. "A New Turn to Authoritarian Rule in Russia?" Democratization 13, no. 1 (2006): 58-77.

Grugel, Jean. Democratization: A Critical Introduction. New York: Palgrave Macmillan, 2002.

Habermas, Jürgen. The Structural Transformation of the Public Sphere: An Inquiry into a Category of Bourgeois Society. Cambridge, Mass.: MIT Press, 1989.

Hamilton, Alexander, James Madison, and John Jay. The Federalist. Cleveland: The World Publishing Company, 1961.

Handelman, Howard. The Challenge of Third World Development, Fourth Edition. Upper Saddle River, N.J.: Pearson Prentice Hall, 2006.

Hayek, Friedrich. The Constitution of Liberty. London: Routledge \& Kegan Paul, 1960.

Held, David. Models of Democracy, 3rd Edition. Stanford: Stanford University Press, 2006.

Herman, Edward S. and Noam Chomsky. Manufacturing Consent: The Political Economy of the Mass Media. New York: Pantheon Books, 2002.

Hobbes, Thomas. "Leviathan." In Classics of Moral and Political Theory, Third Edition, edited by Michael L. Morgan, 491-621. Indianapolis, IN: Hackett Publishing Company, Inc., 2001. 
Huntington, Samuel. "The Clash of Civilizations?" Foreign Affairs 72, no. 3 (1993): 2249.

Huntington, Samuel P. "Democracy's Third Wave." In The Global Resurgence of Democracy, edited by Larry Diamond and Marc F. Plattner, 3-25. Baltimore: John Hopkins University Press, 1996.

Ignatieff, Michael. The Rights Revolution. Toronto: House of Anansi Press, Inc., 2000. Institut kompleksnykh sotsial'nykh issledovanii RAN, “Perestroika glazami rossiian: 20 let spustia," Sotsis sotsiologicheskie issledovaniia 9, no. 257 (2005): 23-36. International Foundation for Electoral Systems, "IFES Election Guide," www.electionguide.org (accessed Nov. 18, 2009).

Katz, Richard S. Democracy and Elections. Oxford: Oxford University Press, 1997.

Khrustov, Genrikh. "Sud'by demokratii v Rossii," Polis politicheskie issledovaniia 1, no. 103 (2008): 183-188.

Kiva, Aleksei. “Kakoi rezhim formiruetsia v Rossii?” Svobodnaia mysl' 12, no. 1583 (2007): 5-16.

Knox, Zoe, Pete Lentini, and Brad Williams. "Parties of Power and Russian Politics: A Victory of the State over Civil Society?" Problems of Post-Communism 53, no. 1 (2006): 3-14.

Kolstø, Pål. "Values and State Ideology in Post-Communist Russia." In Nation-building and Common Values in Russia, edited by Pål Kolstø and Helge Blakkisrud, 327340. Lanham, Maryland: Rowman \& Littlefield Publishers, Inc., 2004.

Kryshtanovskaya, Olga and Stephen White. "Putin's Militocracy," Post-Soviet Affairs 19 , no. 4 (2003): 289-306. 
Kymlicka, Will. "Individual and Community Rights." In Group Rights, edited by Judith Baker, 17-33. Toronto: University of Toronto Press, 1994.

Levada, Yuri A. "What the Polls Tell Us," Journal of Democracy 15, no. 3 (2004): 4351.

Linz, Juan J. and Alfred Stepan. Problems of Democratic Consolidation and Transition: Southern Europe, South America, and Post-Communist Europe. Baltimore: John Hopkins University Press, 1996.

Lively, Jack. Democracy. Oxford: Basil Blackwell, 1975.

Locke, John. "Second Treatise of Government." In Classics of Moral and Political Theory, Third Edition, edited by Michael L. Morgan, 624-689. Indianapolis, IN: Hackett Publishing Company, Inc., 2001.

Machiavelli, Niccolo. "Discourses." In Classics of Moral and Political Theory, Third Edition, edited by Michael L. Morgan, 467-487. Indianapolis, IN: Hackett Publishing Company, Inc., 2001.

Machiavelli, Niccolo. “The Prince." In Classics of Moral and Political Theory, Third Edition, edited by Michael L. Morgan, 422-466. Indianapolis, IN: Hackett Publishing Company, Inc., 2001.

Macpherson, C. B. The Real World of Democracy. Oxford: Oxford University Press, 1966.

Marsh, Christopher. "The Challenge of Civil Society." In Russia's Policy Challenges: Security, Stability, and Development, edited by Stephen K. Wegren, 141-158. Armonk, N.Y.: M.E. Sharpe, Inc., 2003.

Marx, Karl. The Communist Manifesto. London: Penguin Books, 2002. 
Mayo, H.B. An Introduction to Democratic Theory. New York: Oxford University Press, 1960.

McDaniel, Tim. The Agony of the Russian Idea. Princeton: Princeton University Press, 1996.

McFaul, Michael, Nikolai Petrov, and Andrei Ryabov. Between Dictatorship and Democracy: Russian Post-Communist Political Reform. Washington: Carnegie Endowment for International Peace, 2004.

McGann, Anthony. The Logic of Democracy: Reconciling Equality, Deliberation, and Minority Protection. Ann Arbor: The University of Michigan Press, 2006.

McLean, Iain, ed. Oxford Concise Dictionary of Politics. Oxford: Oxford University Press, 1996.

Melville, A. Iu. Politicheskii atlas sovremennosti. Moscow: MGIMO-Universitet, 2007. Mickiewicz, Ellen. “The Election News Story on Russian Television: A World Apart from Viewers," Slavic Review 65, no. 1 (2006): 1-23.

Migranyan, Andranik. "What is Putinism?" Russia in Global Affairs 2, no. 2 (2004): 2844.

Mill, James. An Essay on Government. Indianapolis: The Liberal Arts Press, Inc., 1955. Mill, John Stuart. On Liberty. New York: Liberal Arts Press, 1956.

Montesquieu. The Spirit of Laws. Berkeley: University of California Press, 1977.

Moore, Barrington. Social Origins of Dictatorship and Democracy: Lord and Peasant in the Making of the Modern World. Boston: Beacon Press, 1966.

Moraski, Bryon. "Electoral System Reform in Democracy’s Grey Zone: Lessons from Putin's Russia," Government and Opposition 41, no. 4 (2007): 536-563. 
Morozov, Viacheslav. "Suverennaia demokratiia v postsuverennom mire: putinskaia restavratsiia kak reaktsionnaia modernizatsiia," Heprikosnovennyi zapas 50, no. 6 (2006), http://magazines.russ.ru/nz/2006/50/mo9.html (accessed Mar. 3, 2009).

Moses, Joel C. “Russia's Struggle for Democracy.” In Russia's Policy Challenges:

Security, Stability, and Development, edited by Stephen K. Wegren, 159-178. Armonk, N.Y.: M.E. Sharpe, Inc., 2003.

Nalivkina, N.V. "Demokraticheskie perekhody i neudacha demokraticheskogo tranzita Rossii," Vestnik TGPU (Tomskii gosudarstvennyi pedagogicheskii universitet) 12 , no. 63 (2006): $83-88$.

Naumov, Sergei and Nikolai Slonov, "Suverennaia demokratiia: Eshche raz k voprosu o termine," Svobodnaia mysl' 1574, no. 3 (2007): 21-30.

Oates, Sarah. "Media, Civil Society, and the Failure of the Fourth Estate in Russia." In Russian Civil Society: A Critical Assessment, edited by Alfred B. Evans, Jr., Laura A. Henry, Lisa McIntosh Sundstrom, 57-69. Armonk, N.Y.: M.E. Sharpe, 2006.

Oates, Sarah. Television, Democracy and Elections in Russia. London: Routledge, 2006.

Petukhov, Vladimir. "Perspektivy transformatsii: Dinamika ideino-politicheskikh predpochtenii rossiian," Svobodnaia mysl' 1556, no. 6 (2005): 60-74.

President of Russia, "Meeting with Members of the Valdai International Discussion Club, Sept. 14, 2007," http://eng.kremlin.ru/speeches/2007/09/14/1801_ type82917type84779_144106.shtml (accessed Nov. 24, 2009). 
President of Russia, "Press Conference on the Results of Russian-American Talks, Feb. 24, 2005," http://eng.kremlin.ru/text/speeches/2005/02/24/2307_ type82914type82915_84525.shtml (accessed Nov. 24, 2009).

Pushkov, Alexey. "Putin at the helm," in Chaillot Paper n. 74: What Russia Sees, edited by Dov Lynch, 45-60. Paris: Institute for Security Studies, 2005.

Putin, Vladimir. "Rossiia na rubezhe tysiachetletii," Nezavisimaia gazeta, December 30, 1999, http://www.ng.ru/politics/1999-12-30/4_millenium.html (accessed Nov. 19, 2009).

Rousseau, Jean Jacques. The Social Contract. New York: Hafner Publishing Co., 1947. Russian Federation. The Constitution of the Russian Federation. http://www.departments.bucknell.edu/russian/const/ch2.html (accessed Nov. 10, 2009).

Ryzhkov, Vladimir. "The Liberal Debacle," Journal of Democracy 15, no. 3 (2004): 52 58.

Samuilov, Sergei. “O Rossii kak o severnoi tsivilizatsii,” Svobodnaia mysl' 5, no. 1576 (2007): 21-34.

Sartori, Giovanni. "Concept Misformation in Comparative Politics," The American Political Science Review 64, no. 4 (1970): 1033-1053.

Schumpeter, Joseph A. Capitalism, Socialism and Democracy. London: Unwin Paperbacks, 1987.

Sen, Amartya. “Democracy as a Universal Value," Journal of Democracy 10, no. 3 (1999): 3-17.

Sen, Amartya. Development as Freedom. New York: Alfred A. Knopf, Inc., 1999. 
Shevtsova, Lilia. Russia - Lost in Transition. Washington: Carnegie Endowment for International Peace, 2007.

Shimov, Iaroslav. "Epokha Vladimira Putina i transformatsiia rossiiskoi gosudarstvennosti," Neprikosnovennyi zapas 57, no. 1 (2008).

Shleifer, Andrei. A Normal Country: Russia after Communism. Cambridge, Mass.: Harvard University Press, 2005.

Simonov, Alexei. “Media as Mouthpiece,” Index on Censorship 4, (2005): 78-82.

Talmon, J. L. The Origins of Totalitarian Democracy. London: Secker \& Warburg, 1952.

Taylor, Charles. "Invoking Civil Society," Working Papers and Proceedings of the Center for Psychosocial Studies, no. 31. Chicago: Center for Psychosocial Studies, 1990.

Thompson, John B. The Media and Modernity: A Social Theory of the Media. Stanford: Stanford University Press, 1995.

Thucydides, History of the Peloponnesian War. London: Penguin Books, 1954 and 1972.

Tilly, Charles. Democracy. Cambridge: Cambridge University Press, 2007.

Vitushkin, D. A. "Perspektivy pravokonservativnoi ideologii v sovremennoi rossii," Politanaliz, http://politanaliz.land.ru/right-conservatism1.htm, 2006 (accessed Feb. 17, 2009).

VTsIOM, “Obshcherossiiskii omnibus (ekspress)," http://wciom.ru/issledovanijapolitika/ obshcherossiiskii-omnibus.html (accessed Nov. 16, 2009). 
VTsIOM, "Press-vypusk: 1 fevralia 2002 goda," http://wciom.ru/arkhiv/tematicheskiiarkhiv/item/single/282.html?no_cache $=1 \& \mathrm{cHash}=13 \mathrm{ffe} 1 \mathrm{~d} 426($ accessed Nov. 16, 2009).

VTsIOM, "Press-vypusk: 28 sentiabria 2000 goda," http://wciom.ru/arkhiv/tematicheskii-arkhiv/item/single/454.html?no_cache $=1 \& \mathrm{cHash}=32 \mathrm{fc} 680393$ (accessed Nov. 16, 2009).

White, Stephen, and Sarah Oates. "Politics and the Media in Postcommunist Russia," Politics 23, no. 1 (2003): 31-37.

Whitefield, Stephen. "Russian Citizens and Russian Democracy: Perceptions of State Governance and Democratic Practice, 1993-2007," Post-Soviet Affairs 25, no. 2 (2009): 93-117.

Williams, Melissa S. "Group Inequality and the Public Culture of Justice." In Group Rights, edited by Judith Baker, 34-65. Toronto: University of Toronto Press, 1994.

Zakaria, Fareed. "The Rise of Illiberal Democracy," Foreign Affairs 76, no. 6 (1997): $22-43$. 